Prepared in cooperation with the California State Water Resources Control Board A product of the California Groundwater Ambient Monitoring and Assessment (GAMA) Program

\title{
Groundwater-Quality Data in the Colorado River Study Unit, 2007: Results from the California GAMA Program
}

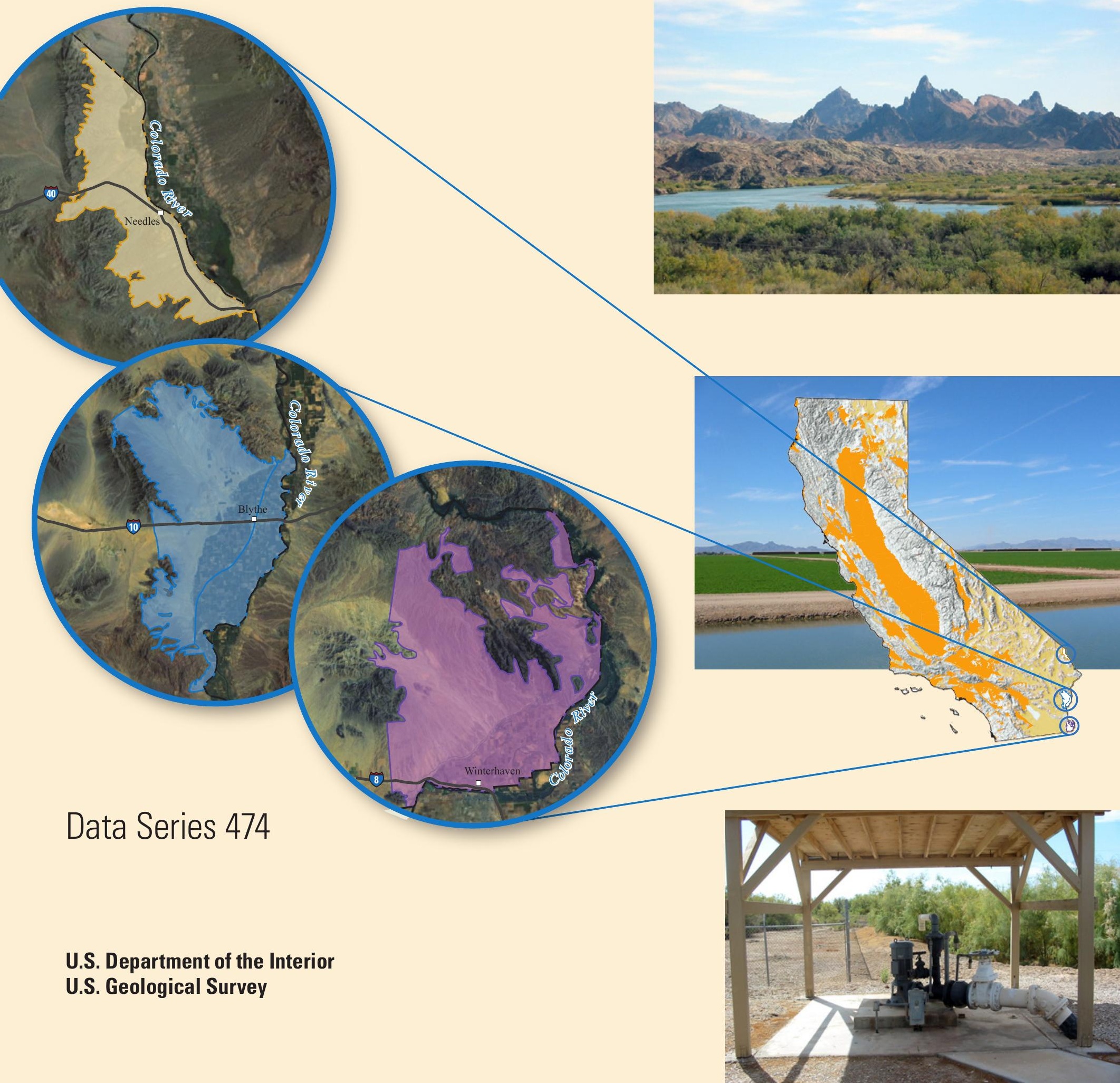


Cover photographs:

Top: Colorado River and Needles Mountains, California. (Photograph taken by Mary Ray, U.S. Geological Survey.)

Middle: Irrigation canal and field near Blythe, California. (Photograph taken by Michael Wright, U.S. Geological Survey.)

Bottom: Well sampled near Palo Verde, California. (Photograph taken by Jill Densmore, U.S. Geological Survey.) 


\section{Groundwater-Quality Data in the Colorado River Study Unit, 2007: Results from the California GAMA Program}

By Dara A. Goldrath, Michael T. Wright, and Kenneth Belitz

Prepared in cooperation with California State Water Resources Control Board

Data Series 474 


\title{
U.S. Department of the Interior \\ KEN SALAZAR, Secretary \\ U.S. Geological Survey \\ Marcia K. McNutt, Director
}

\section{U.S. Geological Survey, Reston, Virginia: 2010}

\author{
For more information on the USGS — the Federal source for science about the Earth, its natural and living resources, \\ natural hazards, and the environment, visit http://www.usgs.gov or call 1-888-ASK-USGS \\ For an overview of USGS information products, including maps, imagery, and publications, \\ visit http://www.usgs.gov/pubprod \\ To order this and other USGS information products, visit http://store.usgs.gov
}

\begin{abstract}
Any use of trade, product, or firm names is for descriptive purposes only and does not imply endorsement by the U.S. Government.

Although this report is in the public domain, permission must be secured from the individual copyright owners to reproduce any copyrighted materials contained within this report.
\end{abstract}

Suggested citation:

Goldrath, D.A., Wright, M.T., and Belitz, Kenneth, 2010, Groundwater-quality data in the Colorado River study unit, 2007: Results from the California GAMA program: U.S. Geological Survey Data Series 474, 66 p. Available at http:// pubs.usgs.gov/ds/474/ 


\section{Contents}

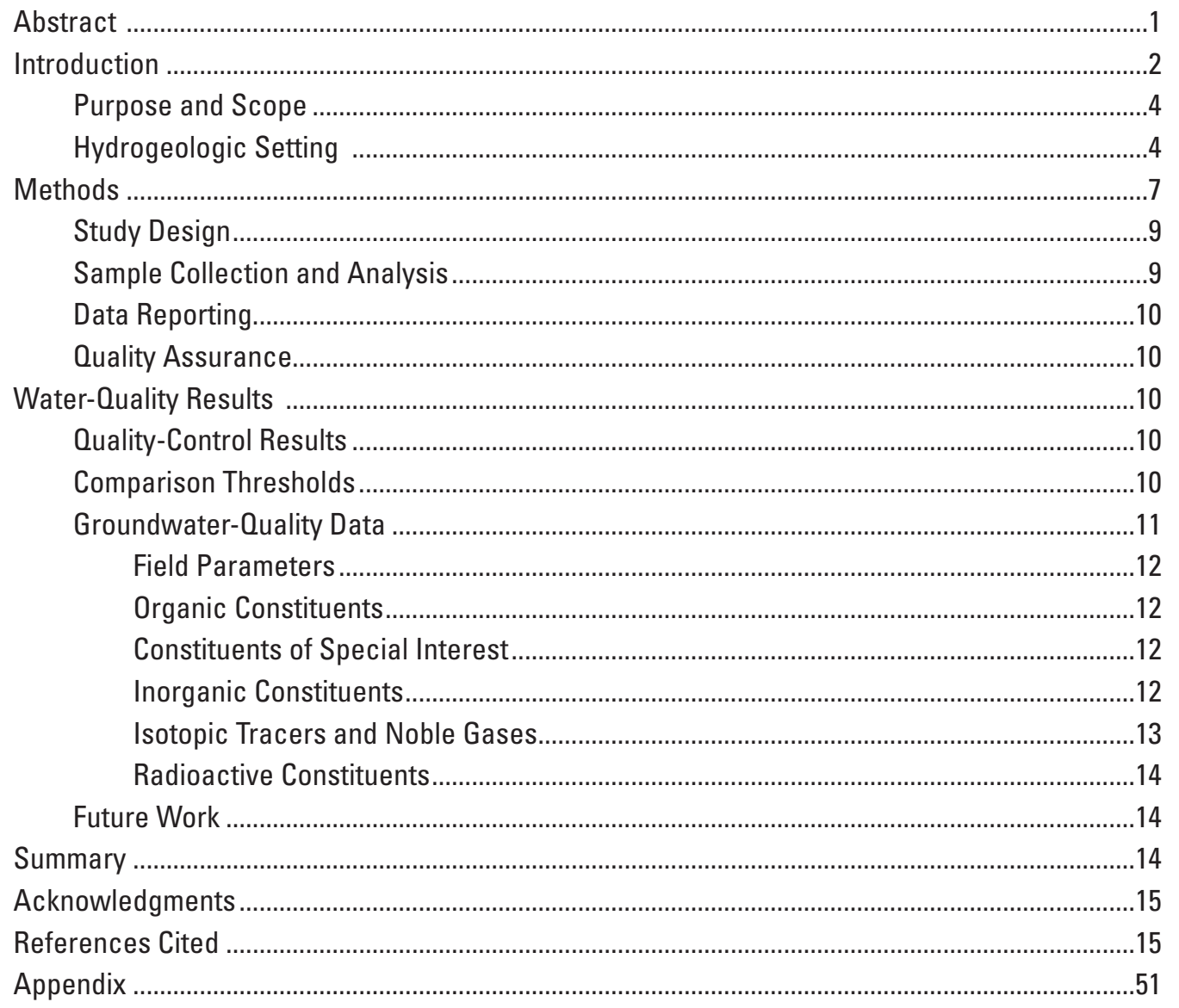




\section{Figures}

1-4. Maps showing

1. The hydrogeologic provinces of California and the location of the Colorado River Groundwater Ambient Monitoring and Assessment (GAMA)

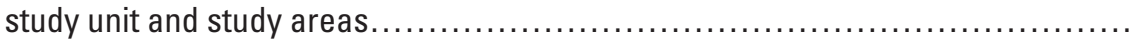

2. The Needles Valley study area of the Colorado River Groundwater Ambient Monitoring and Assessment (GAMA) Study unit showing the 3-km buffer zones around all public-supply wells, the distribution of study-area grid cells, and the locations of sampled grid wells and understanding wells.....

3. The Palo Verde study area of the Colorado River Groundwater Ambient Monitoring and Assessment (GAMA) Study unit showing the 3-km buffer zones around all public-supply wells, the distribution of study-area grid cells, and the locations of sampled grid wells and understanding wells

4. The Yuma Valley study area of the Colorado River Groundwater Ambient Monitoring and Assessment (GAMA) Study unit showing the 3-km buffer zones around all public-supply wells, the distribution of study-area grid cells, and the locations of sampled grid wells

\section{Tables}

1. Well identification and sampling and construction information for wells sampled for the Colorado River Groundwater Ambient Monitoring and Assessment (GAMA) study, California, autumn 2007.

2. Classes of chemical constituents and water-quality indicators collected for the Colorado River Groundwater Ambient Monitoring and Assessment (GAMA) study, California, autumn 2007

3A. Volatile organic compounds, primary uses or sources, comparative thresholds, and reporting information for the U.S. Geological Survey (USGS) National Water Quality Laboratory Schedule 2020

3B. Gasoline oxygenates and degradates, primary uses or sources, comparative thresholds, and reporting information for the U.S. Geological Survey (USGS) National Water Quality Laboratory Schedule 4024

3C. Pesticides and pesticide degradates, primary uses or sources, comparative thresholds, and reporting information for the U.S. Geological Survey (USGS) National Water Quality Laboratory Schedule 2003

3D. Pharmaceutical compounds, primary uses or sources, comparative thresholds, and reporting information for the U.S. Geological Survey (USGS) National Water Quality Laboratory Schedule 9003

$3 \mathrm{E}$. Constituents of special interest, primary uses or sources, comparative thresholds, and reporting information for Weck Laboratories, Inc.

3F. Nutrients, comparative thresholds, and reporting information for the U.S. Geological Survey (USGS) National Water Quality Laboratory Schedule 2755

3G. Major and minor ions and trace elements, comparative thresholds, and reporting information for the U.S. Geological Survey (USGS) National Water Quality Laboratory Schedule 1948 
3H. Arsenic, chromium, and iron species, comparative thresholds, and reporting information for the U.S. Geological Survey (USGS) Trace Metal Laboratory, Boulder, Colorado 34

3l. Isotopic and radioactive constituents, comparative thresholds, and reporting information for laboratories 35

3J. Noble gases and tritium, comparison thresholds and reporting information for the Lawrence Livermore National Laboratory

4. Water-quality indicators in samples collected for the Colorado River Groundwater Ambient Monitoring and Assessment (GAMA) study, California, autumn 2007

5. Volatile organic compounds (VOC) detected in samples collected for the Colorado River Groundwater Ambient Monitoring and Assessment (GAMA) study, California, autumn 2007

6. Pesticides and pesticide degradates detected in samples collected for the Colorado River Groundwater Ambient Monitoring and Assessment (GAMA) study, California, autumn 2007

7. Constituents of special interest (perchlorate and 1,2,3-trichloropropane) detected in samples collected for the Colorado River Groundwater Ambient Monitoring and Assessment (GAMA) study, California, autumn 2007

8. Nutrients detected in samples collected for the Colorado River Groundwater Ambient Monitoring and Assessment (GAMA) study, California, autumn 2007

9. Major and minor ions and dissolved solids detected in samples collected for the Colorado River Groundwater Ambient Monitoring and Assessment (GAMA) study, California, autumn 2007

10. Trace elements detected in groundwater samples collected for the Colorado River Groundwater Ambient Monitoring and Assessment (GAMA) study, California, autumn 2007

11. Species of inorganic iron, arsenic, and chromium detected in samples collected for the Colorado River Groundwater Ambient Monitoring and Assessment (GAMA) study, California, autumn 2007

12. Stable isotope ratios and activities of tritium and carbon-14 detected in samples collected for the Colorado River Groundwater Ambient Monitoring and Assessment (GAMA) study, California, autumn 2007

13A. Radium isotopes detected in samples collected for the Colorado River Groundwater Ambient Monitoring and Assessment (GAMA) study, California, autumn 2007

13B. Gross alpha and gross beta radioactivity detected in samples collected for the Colorado River Groundwater Ambient Monitoring and Assessment (GAMA) study, California, autumn 2007 49

13C. Radon-222 detected in samples collected for the Colorado River Groundwater Ambient Monitoring and Assessment (GAMA) study, California, autumn 2007 


\section{Appendix Tables:}

A1. Analytical methods used to measure organic and inorganic constituents by the U.S. Geological Survey (USGS) National Water Quality Laboratory (NWQL) and other laboratories

A2. Preferred analytical schedules for constituents appearing on multiple schedules for samples collected for the Colorado River Groundwater Ambient Monitoring and Assessment (GAMA) study, California, autumn 2007

A3. Constituents detected in field blanks collected for the Colorado River Groundwater Ambient Monitoring and Assessment (GAMA) study, California, autumn 2007

A4. Quality-control summary of replicate analyses of constituents detected in samples collected for the Colorado River Groundwater Ambient Monitoring and Assessment (GAMA) study, California, autumn 2007.

A5A. Quality-control summary of matrix-spike recoveries of volatile organic compounds (VOC) in samples collected for the Colorado River Groundwater Ambient Monitoring and Assessment (GAMA) study, California, autumn 2007

A5B. Quality-control summary of matrix-spike recoveries of pesticides and pesticide degradates in samples collected for the Colorado River Groundwater Ambient Monitoring and Assessment (GAMA) study, California, autumn 2007 ...... 64

A5C. Quality-control summary for matrix-spike recoveries of 1,4-dioxane and 1,2,3-trichloropropane (1,2,3-TCP) in groundwater samples collected for the Colorado River Groundwater Ambient Monitoring and Assessment (GAMA) study, California, autumn 2007

A6. Quality-control summary for surrogate recoveries of volatile organic compounds, pesticides and pesticide degradates, and constituents of special interest in samples collected for the Colarado River Groundwater Ambient Monitoring and Assessment (GAMA) study, California, autumn 2007 


\title{
Abbreviations and Acronyms
}

\author{
(Additional information or clarification given in parentheses) \\ AB Assembly Bill (through the California State Assembly) \\ CAS Chemical Abstract Service (American Chemical Society) \\ COLOR Colorado River Study unit or Colorado River Study unit grid well \\ COLORU Colorado River Study unit understanding well \\ CSU combined standard uncertainty \\ E estimated or having a higher degree of uncertainty \\ GAMA Groundwater Ambient Monitoring and Assessment program \\ GPS Global Positioning System \\ HAL-US lifetime health advisory level (USEPA) \\ HPLC high-performance liquid chromatography \\ LRL laboratory reporting level \\ LSD land-surface datum \\ LT-MDL long-term method detection level \\ MCL-US maximum contaminant level (USEPA) \\ MCL-CA maximum contaminant level (CDPH) \\ MDL method detection limit \\ MRL minimum reporting level \\ MU method uncertainty \\ $\mathrm{N} \quad$ Normal (1-gram-equivalent per liter of solution) \\ NL-CA notification level (CDPH) \\ NWIS National Water Information System (USGS) \\ PCFF personal computer field forms program designed for USGS sampling \\ OC quality control \\ RPD relative percent difference \\ RSD relative standard deviation \\ RSD5 risk-specific dose at $10^{-5}$ (USEPA) \\ SMCL-CA secondary maximum contaminant level (CDPH) \\ ssLC sample-specific critical level \\ US United States \\ VPDB Vienna Pee Dee Belemnite \\ VSMOW Vienna Standard Mean Ocean Water
}




$\begin{array}{ll}\text { Organizations } & \\ \text { CDPH } & \text { California Department of Public Health } \\ \text { DWR } & \text { California Department of Water Resources } \\ \text { USEPA } & \text { U.S. Environmental Protection Agency } \\ \text { LLNL } & \text { Lawrence Livermore National Laboratory } \\ \text { MWH } & \text { Montgomery Watson Harza } \\ \text { NAWQA } & \text { National Water Quality Assessment (USGS) } \\ \text { NWQL } & \text { National Water Quality Laboratory (USGS) } \\ \text { SWRCB } & \text { State Water Resources Control Board (California) } \\ \text { USGS } & \text { U.S. Geological Survey } \\ \text { WECK } & \text { Weck Laboratories, Inc. }\end{array}$

\section{Selected chemical names}

$\begin{array}{ll}\mathrm{CaCO}_{3} & \text { calcium carbonate } \\ \mathrm{CFC} & \text { chlorofluorocarbon } \\ \mathrm{CO}_{3}^{-2} & \text { carbonate } \\ \mathrm{HCl} & \text { hydrochloric acid } \\ \mathrm{HCO}_{3}^{-} & \text {bicarbonate } \\ \mathrm{MTBE} & \text { methyl tert-butyl ether } \\ \mathrm{NDMA} & \mathrm{N} \text {-nitrosodimethylamine } \\ \mathrm{PCE} & \text { perchloroethene, tetrachloroethene } \\ \text { TCP } & \text { trichloropropane } \\ \text { TDS } & \text { total dissolved solids } \\ \text { THM } & \text { trihalomethane } \\ \text { VOC } & \text { volatile organic compound }\end{array}$

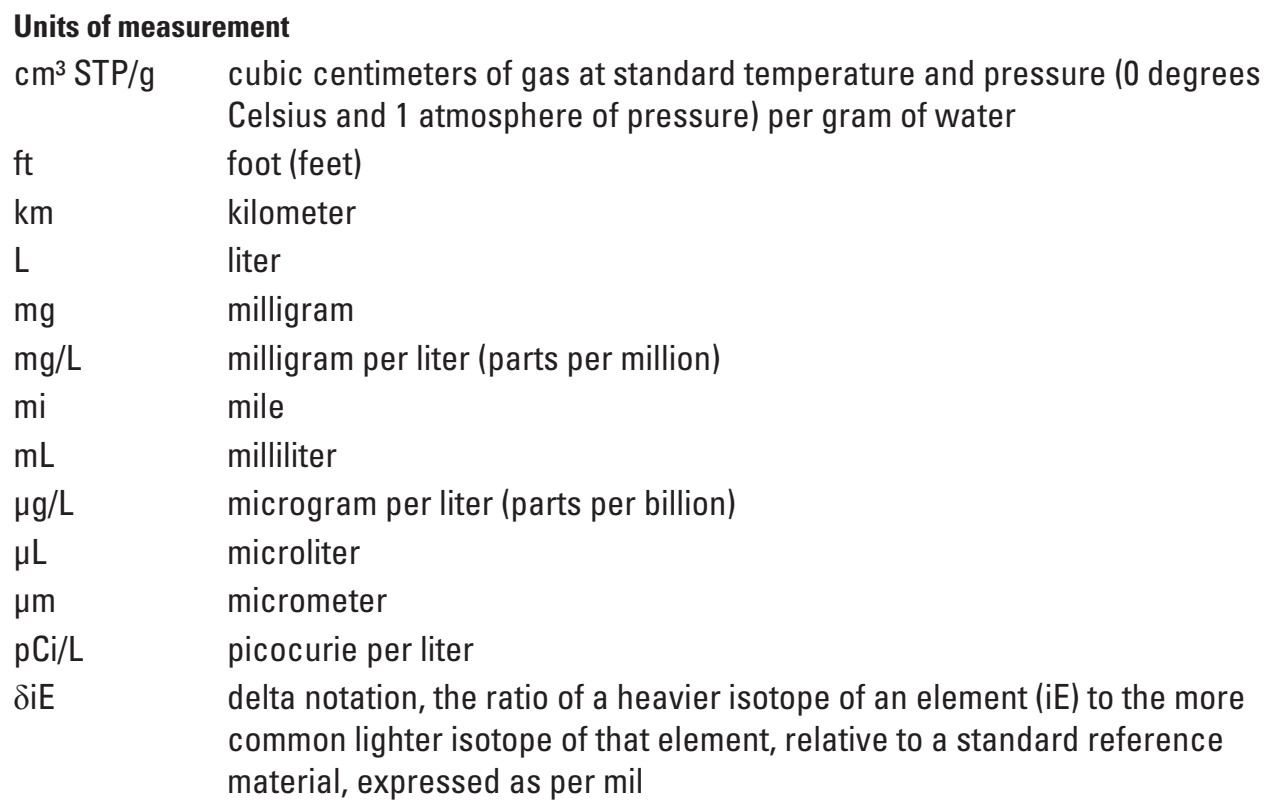




\section{Notes}

Temperature in degrees Celsius $\left({ }^{\circ} \mathrm{C}\right)$ may be converted to degrees Fahrenheit $\left({ }^{\circ} \mathrm{F}\right)$ as follows:

$$
{ }^{\circ} \mathrm{F}=\left(1.8 x^{\circ} \mathrm{C}\right)+32
$$

Vertical coordinate information is referenced to the North American Vertical Datum of 1988 (NAVD 88).

Well depths in are given in feet below land-surface datum (LSD), which is a datum plane that is approximately at land surface. The LSD for each well is referenced to NAVD 88.

Specific conductance is given in microsiemens per centimeter at 25 degrees Celsius $(\mu \mathrm{S} / \mathrm{cm}$ at $\left.25^{\circ} \mathrm{C}\right)$.

Concentrations of chemical constituents in water are given either in milligrams per liter ( $\mathrm{mg} / \mathrm{L})$ or micrograms per liter $(\mu \mathrm{g} / \mathrm{L})$. Milligrams per liter is equivalent to parts per million (ppm) and micrograms per liter is equivalent to parts per billion (ppb) 
This page intentionally left blank. 


\title{
Groundwater-Quality Data in the Colorado River Study Unit, 2007: Results from the California GAMA Program
}

\author{
By Dara A. Goldrath, Michael T. Wright, and Kenneth Belitz
}

\begin{abstract}
Groundwater quality in the 188-square-mile Colorado River Study unit (COLOR) was investigated October through December 2007 as part of the Priority Basin Project of the California State Water Resources Control Board (SWRCB) Groundwater Ambient Monitoring and Assessment (GAMA) Program. The GAMA Priority Basin Project was developed in response to the Groundwater Quality Monitoring Act of 2001, and the U.S. Geological Survey (USGS) is the technical project lead.

The Colorado River study was designed to provide a spatially unbiased assessment of the quality of raw groundwater used for public water supplies within COLOR, and to facilitate statistically consistent comparisons of groundwater quality throughout California. Samples were collected from 28 wells in three study areas in San Bernardino, Riverside, and Imperial Counties. Twenty wells were selected using a spatially distributed, randomized grid-based method to provide statistical representation of the Study unit; these wells are termed 'grid wells'. Eight additional wells were selected to evaluate specific water-quality issues in the study area; these wells are termed 'understanding wells.'

The groundwater samples were analyzed for organic constituents (volatile organic compounds [VOC], gasoline oxygenates and degradates, pesticides and pesticide degradates, pharmaceutical compounds), constituents of special interest (perchlorate, 1,4-dioxane, and 1,2,3-trichlorpropane [1,2,3-TCP]), naturally occurring inorganic constituents (nutrients, major and minor ions, and trace elements), and radioactive constituents. Concentrations
\end{abstract}

of naturally occurring isotopes (tritium, carbon-14, and stable isotopes of hydrogen and oxygen in water), and dissolved noble gases also were measured to help identify the sources and ages of the sampled groundwater. In total, approximately 220 constituents and water-quality indicators were investigated.

Quality-control samples (blanks, replicates, and matrix spikes) were collected at approximately 30 percent of the wells, and the results were used to evaluate the quality of the data obtained from the groundwater samples. Field blanks rarely contained detectable concentrations of any constituent, suggesting that contamination was not a significant source of bias in the data. Differences between replicate samples were within acceptable ranges and matrix-spike recoveries were within acceptable ranges for most compounds.

This study did not attempt to evaluate the quality of water delivered to consumers; after withdrawal from the ground, raw groundwater typically is treated, disinfected, or blended with other waters to maintain acceptable water quality. Regulatory thresholds apply to water that is served to the consumer, not to raw groundwater. However, to provide some context for the results, concentrations of constituents measured in the raw groundwater were compared to regulatory and nonregulatory health-based thresholds established by the U.S. Environmental Protection Agency (USEPA) and the California Department of Public Health (CDPH) and to thresholds established for aesthetic concerns by CDPH. Comparisons between data collected for this study and drinking-water thresholds are for illustrative purposes only and do not indicate compliance or noncompliance with those thresholds. 
The concentrations of most constituents detected in groundwater samples were below drinking-water thresholds. Volatile organic compounds (VOC) were detected in approximately 35 percent of grid well samples; all concentrations were below health-based thresholds. Pesticides and pesticide degradates were detected in about 20 percent of all samples; detections were below healthbased thresholds. No concentrations of constituents of special interest or nutrients were detected above health-based thresholds. Most of the major and minor ion constituents sampled do not have health-based thresholds; the exception is fluoride. Concentrations of chloride, sulfate, and total dissolved solids detected in some of the well samples were above the nonenforceable thresholds for aesthetic concerns. Concentrations of fluoride were detected in 5 samples (from 4 grid wells and 1 understanding well) above the maximum contaminant level for California (MCL-CA). Concentrations of most of the trace elements in samples from the COLOR were below health-based thresholds; exceptions included arsenic above the MCL-US, boron above the notification level for California (NL-CA), iron and manganese above the secondary maximum contaminant level for California (SMCL-CA), and molybdenum and strontium above the lifetime health advisory level (HAL-US) threshold. Most detections of radioactive constituents were below healthbased thresholds; exceptions were alpha, uranium, and radon radioactivity. Alpha radioactivity with 72 hour count detections occurred in four grid wells and one understanding well, and 30-day count detections in two grid wells above the MCL-US. Uranium was detected twice in grid wells above the MCL-US threshold. Also, radon-222 was detected at concentrations above the proposed MCL-US in 19 samples (14 grid and 5 understanding wells). No radon-222 was detected above the proposed MCL-US upper threshold.

\section{Introduction}

Groundwater comprises nearly half of the water used for public supply in California (Hutson and others, 2004). To assess the quality of groundwater in aquifers used for drinking-water supply and to establish a program for monitoring trends in groundwater quality, the State Water Resources Control Board (SWRCB), in collaboration with the U.S. Geological Survey (USGS) and Lawrence Livermore National Laboratory (LLNL), implemented the Groundwater Ambient Monitoring and Assessment (GAMA) Program (http:/www.waterboards.ca.gov/gama). The GAMA Program consists of three projects: Priority Basin Project, conducted by the USGS (http://ca.water.usgs.gov/gama/); Voluntary Domestic Well Assessment, conducted by the SWRCB; and Special Studies, conducted by LLNL.

The SWRCB initiated the GAMA Priority Basin Project in response to the Groundwater Quality Monitoring Act of 2001 (Sections 10780-10782.3 of the California Water Code,
Assembly Bill 599). AB 599 is a public mandate to assess and monitor the quality of groundwater used as public supply in California. The project is a comprehensive assessment of statewide groundwater quality designed to help better understand and identify risks to groundwater resources and to increase the amount of information about groundwater quality available to the public. As part of the AB 599 process, the USGS, in collaboration with the SWRCB, developed the monitoring plan for the project (Belitz and others, 2003; State of California State Water Resources Control Board, 2003). Key aspects of the project are interagency collaboration and cooperation with local water agencies and well owners. Local participation in the project was entirely voluntary.

The GAMA Priority Basins Project is unique because it includes many chemical analyses that otherwise are not available in statewide water-quality monitoring datasets. A broader understanding of groundwater composition will be especially useful for providing an early indication of changes in water quality and for identifying the natural and human factors affecting water quality. Additionally, the GAMA Priority Basin Project will analyze a broader suite of constituents than required by the California Department of Public Health (CDPH; formerly California Department of Health Services, renamed on July 1, 2007). An understanding of the occurrence and distribution of these constituents is important for the long-term management and protection of groundwater resources.

The range of hydrologic, geologic, and climatic conditions that exist in California must be considered when assessing groundwater quality. Belitz and others (2003) partitioned the state into ten hydrogeologic provinces, each with distinctive hydrologic, geologic, and climatic characteristics (fig.1), and representative regions in all 10 provinces were included in the project design. Eighty percent of California's approximately 16,000 publicsupply wells are located in groundwater basins within these hydrologic provinces. These groundwater basins, defined by the California Department of Water Resources, generally consist of relatively permeable, unconsolidated deposits of alluvial or volcanic origin (California Department of Water Resources, 2003). Groundwater basins were prioritized for sampling on the basis of the number of public-supply wells in the basin, with secondary consideration given to municipal groundwater use, agricultural pumping, the number of formerly leaking underground fuel tanks, and pesticide applications within the basins (Belitz and others, 2003). In addition, some groundwater basins or groups of similar adjacent basins with relatively few public-supply wells were assigned high priority so that all hydrogeologic provinces would be represented in the subset of basins sampled as part of the project. The 116 priority basins were grouped into 37 study units. Some areas not in DWR-defined groundwater basins were included in their nearest respective study units to represent the 20 percent of public-supply wells not located in the groundwater basins. 


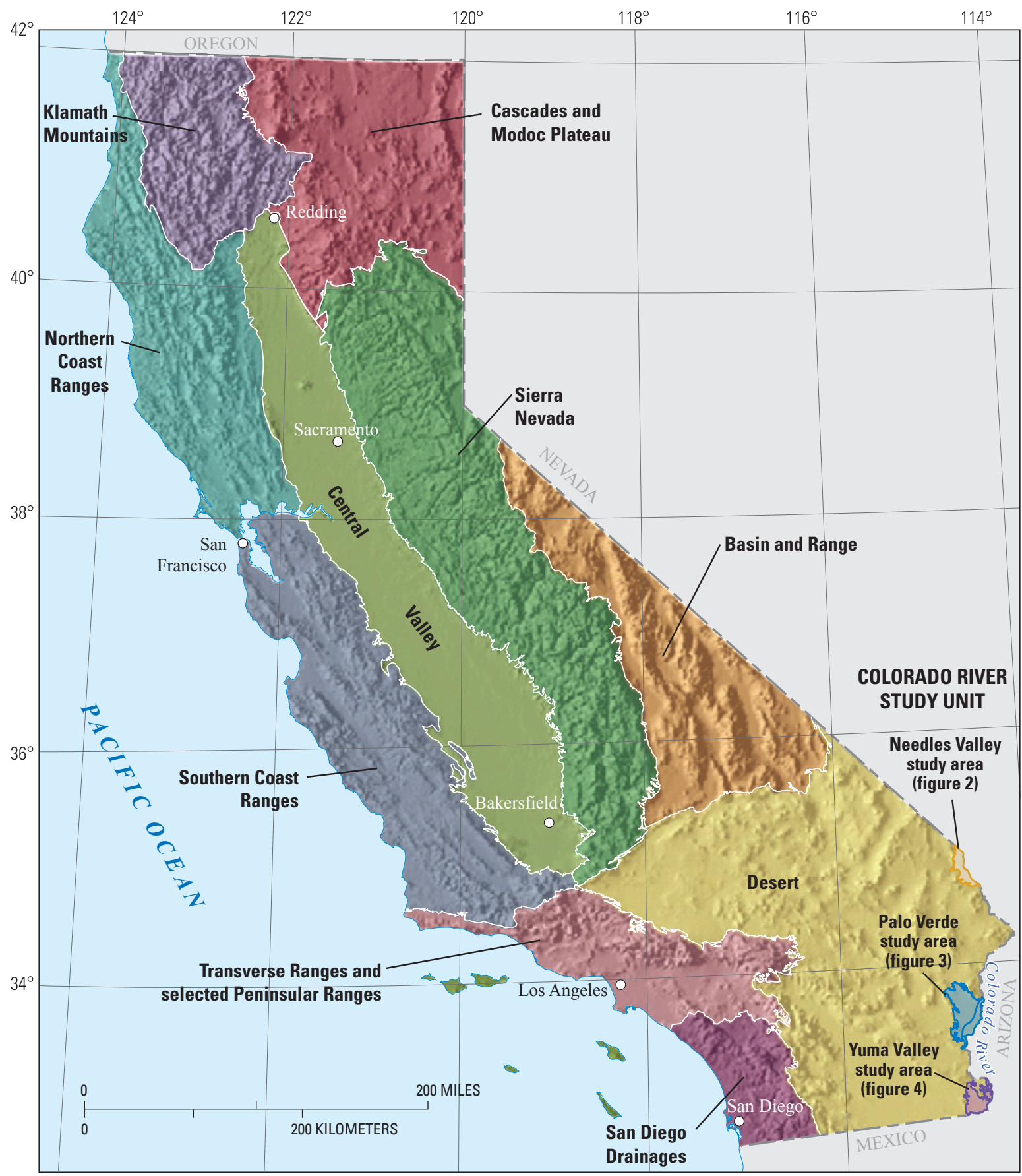

Shaded relief derived from U.S. Geological Survey

Provinces from Belitz and others, 2003

National Elevation Dataset, 2006

Albers Equal Area Conic Projection

Figure 1. Map of the hydrogeologic provinces of California and the location of the Colorado River Groundwater Ambient Monitoring and Assessment (GAMA) study unit and study areas. 
Three types of water-quality assessments are being conducted using the data collected in each study unit: (1) Status: assessment of the current quality of the groundwater resource, (2) Trends: detection of changes in groundwater quality, and (3) Understanding: identification of the natural and human factors affecting groundwater quality (Kulongoski and Belitz, 2004). This report is one of a series of reports presenting water-quality data collected in each study unit (Wright and others, 2005; Bennett and others, 2006; Kulongoski and others, 2006; Fram and Belitz, 2007; Kulongoski and Belitz, 2007; Burton and Belitz, 2008; Dawson and others, 2008; Ferrari and others, 2008; Land and Belitz, 2008; Landon and Belitz, 2008; Mathany and others, 2008; Schmitt and others, 2008; Shelton and others, 2008; Fram and others, 2009; Kent and Belitz, 2009; Goldrath and others, 2009; Montrella and Belitz, 2009; and, Ray and others, 2009; Mathany and Belitz, 2009). Subsequent reports will address the status, trends, and understanding aspects of the water-quality assessments.

The Colorado River GAMA Study unit, hereinafter referred to as COLOR, covers targeted areas of four small groundwater basins: the Needles Valley study area, the Palo Verde study area including both the Palo Verde Valley and Mesa, and the Yuma Valley study area. COLOR was considered a high priority for sampling because it provides representation of the Desert Hydrologic Province and the Colorado River Basins (Belitz and others, 2003). COLOR was the $21^{\text {st }}$ study unit sampled as part of the GAMA Program.

\section{Purpose and Scope}

The purposes of this report are (1) to describe the study design, including the hydrogeologic setting of COLOR and the study methods; (2) to present the results of quality-control tests; and (3) to present the analytical results for groundwater samples collected in the COLOR. Groundwater samples were analyzed for organic and inorganic constituents, field parameters, and chemical tracers. The chemical data presented in this report were evaluated by comparing these data to State and Federal drinking water regulatory and nonregulatory health-based standards that are applied to treated drinking water. Regulatory and nonregulatory thresholds considered for this report are those established by the United States Environmental Protection Agency (USEPA) and the California Department of Public Health (CDPH). The data presented in this report are intended to characterize the quality of untreated (raw) groundwater resources within the study unit, not the treated drinking water delivered to consumers by water purveyors. Discussion of the factors that influence the distribution and occurrence of the constituents detected in groundwater samples will be the subject of subsequent publications.

\section{Hydrogeologic Setting}

Knowledge of the hydrogeologic setting is important in the design of a groundwater-quality investigation. The Colorado River Study unit (COLOR) lies within the Desert Hydrologic Province, described by Belitz and others (2003), in southeastern California and is bounded on the east by the Colorado River, on the west by various desert mountain ranges, on the north by Nevada, and on the south by Mexico (figs. 1,2,3,4). The climate is marked by high summer temperatures and low amounts of precipitation. The annual average precipitation ranges from six inches in the northern area to 3 inches in the southern area (National Climate data Center, 2008). Precipitation falls primarily during the summer monsoon season; a lesser amount occurs during the winter as storms come in from the Pacific Ocean (Hely and Peck, 1964; Pyke, 1972).

Although the COLOR is approximately 150 miles from end to end, the actual area of study is small, only 188 square miles. The COLOR is divided into three small study areas: Needles Valley, Palo Verde, and Yuma Valley (fig.1). The boundaries of the study areas correspond to those of the California Department of Water Resources (DWR) groundwater basins (California Department of Water Resources, 2004a,b,c,d). The Palo Verde study area includes the California DWR delineated Palo Verde Valley and the Palo Verde Mesa groundwater basins (ig, 3 ). 


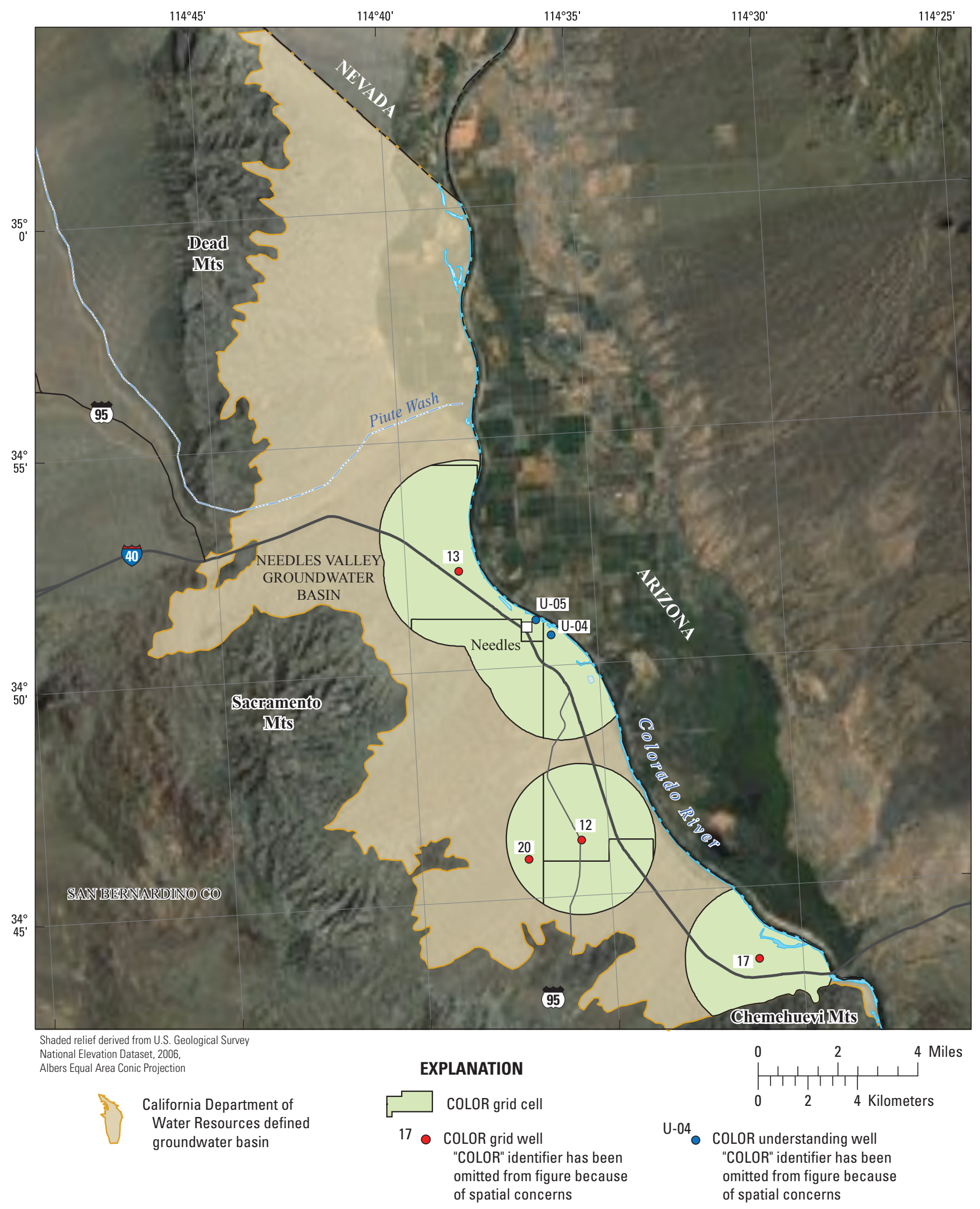

Figure 2. Map of the Needles Valley study area of the Colorado River Groundwater Ambient Monitoring and Assessment (GAMA) Study unit showing the 3-km buffer zones around all public-supply wells, the distribution of study-area grid cells, and the locations of sampled grid wells and understanding wells. Alphanumeric identification numbers for grid wells have the prefix "COLOR." Alphanumeric identification numbers for understanding wells have the prefix "COLORU." 


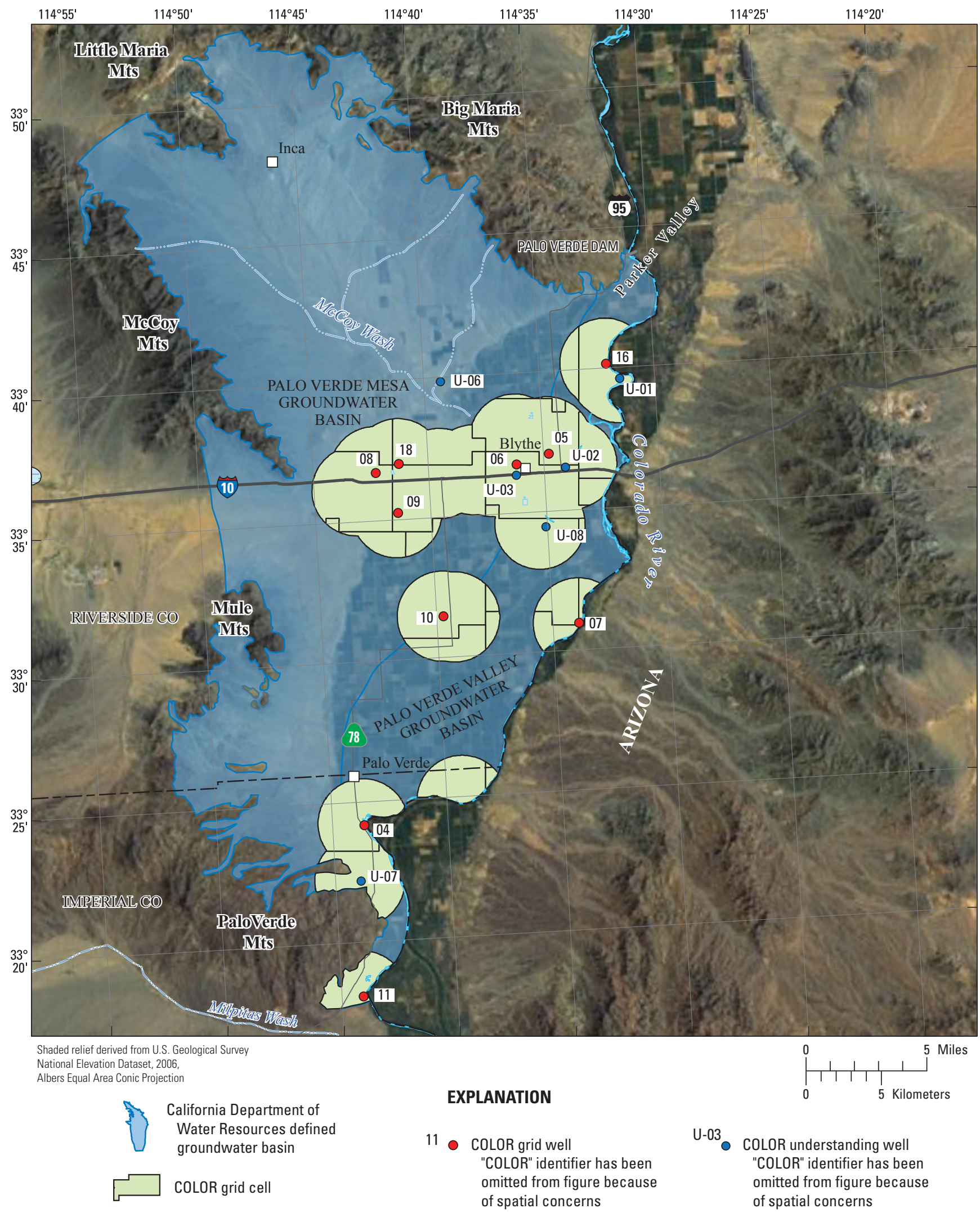

Figure 3. Map of the Palo Verde study area of the Colorado River Groundwater Ambient Monitoring and Assessment (GAMA) Study unit showing the 3-km buffer zones around all public-supply wells, the distribution of study-area grid cells, and the locations of sampled grid wells and understanding wells. Alphanumeric identification numbers for grid wells have the prefix "COLOR." Alphanumeric identification numbers for understanding wells have the prefix "COLORU." 
The 36-square-mile Needles Valley study area is underlain by the Needles Valley groundwater basin, which is located in the eastern part of the Mojave Valley in San Bernardino County (fig. 1, 2). The basin is bounded by the Colorado River to the east, the Dead Mountains to the northwest, the Sacramento Mountains to the southwest, and the Chemehuevi Mountains to the south (Bishop, 1963). The average annual precipitation ranges from 4 to 6 inches, and surface water drains eastward through the Piute Wash to the Colorado River (California Department of Water Resources, 2004a). Two main water-bearing units exist within the Needles Valley groundwater basin: the alluvium (younger and older) and the Bouse Formation. The younger alluvium, Holocene in age, is in washes and in the floodplain area of the Colorado River and is composed of sand, silt, and gravel (Metzger and Loeltz, 1973). The older alluvium, considered to be late Pliocene or older, consists of unconsolidated, fine to coarse grained sand, pebbles, and boulders with inclusions of silt and clay (California Department of Water Resources, 2004a). The alluvial units in this part of the study area are more than 310 feet thick (Metzger and Loeltz, 1973). The Pliocene-age Bouse Formation is as much as 254 feet thick, and is composed of a basal limestone bed that is overlain by interbedded clay, silt sand, and tufa (Metzger and Loeltz, 1973). The Bouse Formation is underlain by a locally derived fanglomerate (California Department of Water Resources, 2004a). An unnamed fault outside of the study area traverses the southern side of the basin (Bishop, 1963); it is not known if the fault impedes the flow of groundwater. Recharge processes in the Needles Valley basin include percolation of the Colorado River, agricultural returns, precipitation, and a minor subsurface inflow from the mountains and uplands on the western side of the study area (Metzger and Loeltz, 1973). The groundwater levels in this basin range from 9 to 12 feet below land surface (Metzger and Loeltz, 1973).

The 108-square-mile Palo Verde study area is underlain by the Palo Verde Valley and the Palo Verde Mesa groundwater basins, which are located in the southeastern portion of Riverside County and the northeastern corner of Imperial County (fig. 3). The basins are bounded by the Colorado River to the east, and the non-water-bearing rocks of the Big Maria and Little Maria Mountains to the north, the McCoy and Mule Mountains to the west, and the Palo Verde Mountains to the south (Jennings, 1967; California Department of Water Resources, 1979). The average annual precipitation ranges up to 6 inches, and surface water drains eastward through the McCoy wash to the Colorado River (California Department of Water Resources, 2004b). In the Palo Verde Mesa groundwater basin, the main waterbearing unit consists of alluvial deposits, Quaternary in age, approximately 600 feet thick (Metzger and others, 1973) and is composed of lenticular beds of sand, gravel, silt, and clay in the basin and coDse-grained angular rock detritus near the mountains (California Department of Water Resources, 1961, 1979). In the Palo Verde Valley groundwater basin, the main water-bearing units include the alluvium deposits, ranging from 130 to 600 feet thick, and the upper Bouse Formation (Metzger and others, 1973). Recharge processes in the Palo Verde Valley and Palo Verde Mesa groundwater basins include mountain side runoff, percolation of the Colorado River, agricultural return through irrigated land and canal seepage (Metzger and others, 1973), precipitation, and a minor component of subsurface inflow from the mountains and uplands on the western side of the study area (California Department of Water Resources, 1979). The groundwater levels in the study areas range from about 5 feet near the Colorado River to about 25 feet in the western edge of the basin (Metzger and others, 1973).

The 44-square-mile Yuma Valley study area is underlain by the Yuma Valley groundwater basin, which is located in Bard Valley, a southeast trending valley in the southeast portion of Imperial County (fig. 4) (Olmsted and others, 1973). The basin is bounded by the Colorado River to the east and south, the non-water-bearing rocks of the Cargo Muchacho Mountains to the west, and the Chocolate Mountains to the north and northeast. The average annual precipitation ranges from 1 to 3 inches, and surface water drains southeast towards the Colorado River (California Department of Water Resources, 1954). The main water bearing unit is comprised of alluvium deposits: an unconsolidated Quaternary alluvium underlain by an unconsolidated to semi-consolidated Tertiary to Quaternary alluvial deposit (California Department of Water Resources, 2004c). The maximum depth of the valley fill alluvium deposits is at least 200 feet (California Department of Water Resources 1954, 1975). Recharge in the Yuma Valley groundwater basin occurs naturally from subsurface inflow through the Ogilby groundwater basin to the west, mountainside runoff infiltrating through the alluvial deposits, and percolation from the Colorado River. Recharge occurs also through seepage loss from the All American Canal and other unlined canals as well as through the percolation of irrigation return flows (California Department of Water Resources, 2004c). Groundwater levels in areas near the Colorado River floodplain south and east of the All American Canal range from 5 to 20 feet, and groundwater levels north or west of the canal range from 40 to 240 feet (California Department of Water Resources, 2004c).

\section{Methods}

Methods used for the GAMA program were selected to achieve the following objectives: (1) design a sampling plan suitable for statistical analysis, (2) collect samples in a consistent manner, (3) analyze samples using proven and reliable laboratory methods, (4) assure the quality of the groundwater data, and (5) maintain data securely and with relevant documentation. The Appendix to this report contains detailed descriptions of the sample collection protocols and analytical methods, the quality-assurance plan, and the results of analyses of quality-control samples. 


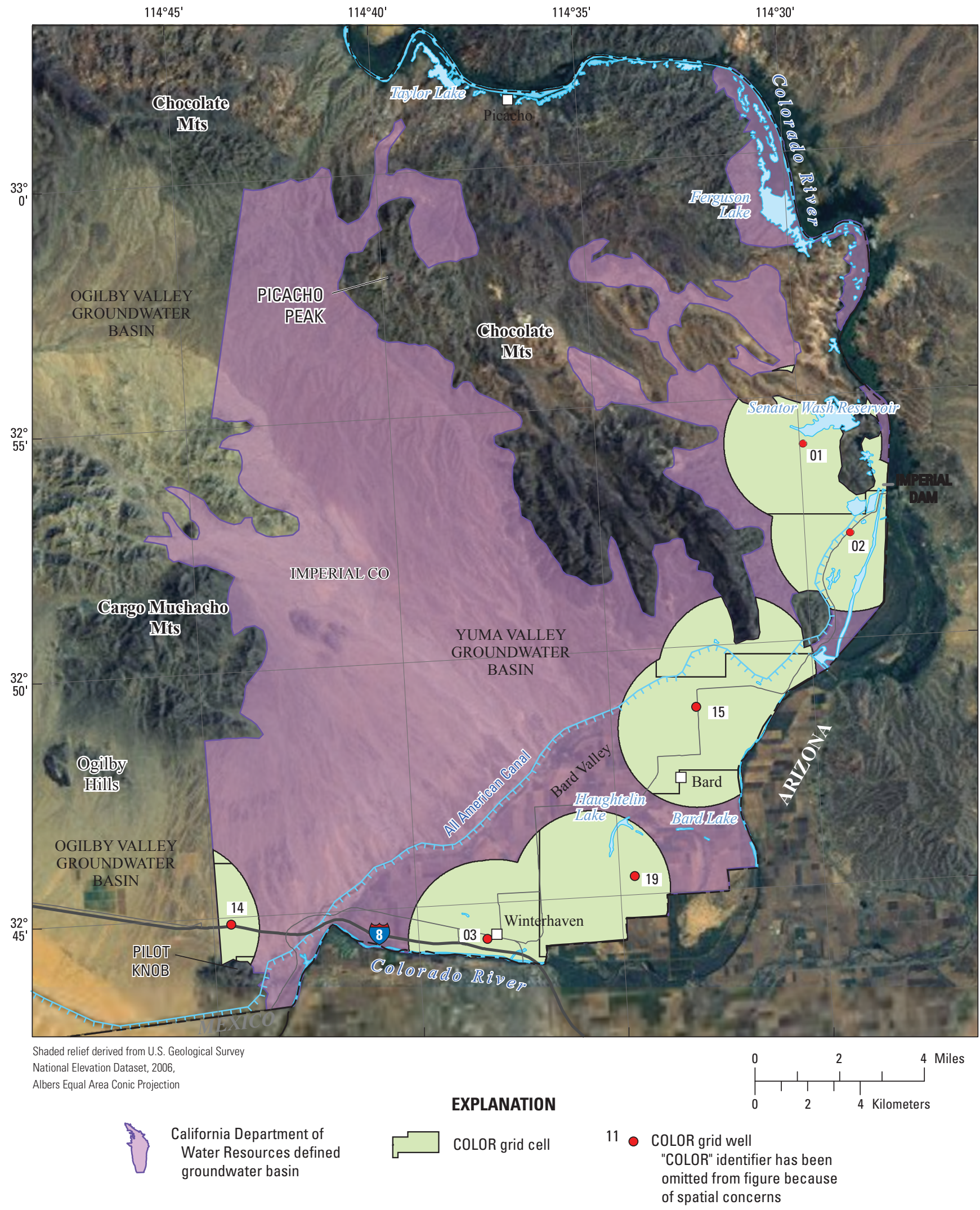

Figure 4. Map of the Yuma Valley study area of the Colorado River Groundwater Ambient Monitoring and Assessment (GAMA) Study unit showing the 3-km buffer zones around all public-supply wells, the distribution of study-area grid cells, and the locations of sampled grid wells. Alphanumeric identification numbers for grid wells have the prefix "COLOR." 


\section{Study Design}

The wells selected for sampling in this study reflect the combination of two well selection strategies. Twenty wells, called "grid" wells, were selected to provide a statistically unbiased, spatially distributed assessment of the quality of groundwater resources used for public drinking-water supply, and eight additional wells, called "understanding" wells, were selected to provide greater sampling density in areas where specific groundwater-quality issues needed to be addressed.

The spatially distributed grid wells were selected using a randomized grid-based method (Scott, 1990). COLOR had relatively few public-supply wells, and these wells were not evenly distributed. To minimize the number of cells without any wells, only the portion of COLOR near a public-supply well was included in the grid area. Locations of public-supply wells listed in the statewide database maintained by the CDPH were plotted, and a 1.86-mi (3-kilometer) radius circle was drawn to form a buffer zone around each well. The areas encompassed by all the circles were then divided into 20 grid cells, approximately $9.7 \mathrm{mi}^{2}$ in area (figs. 2-4). The objective was to select one public-supply well per grid cell.

If a grid cell contained more than one public-supply well, each well was randomly assigned a rank. The highest ranking well that met basic sampling criteria (for example, sampling point located before treatment, capability to pump for several hours, and available well-construction information), and for which permission to sample could be obtained, was then sampled. If a grid cell contained no accessible public-supply wells, domestic and irrigation-use wells were considered for sampling. An attempt was made to select domestic and irrigation wells with depths and screened intervals similar to those in public-supply wells in the area. One well was selected in each cell to provide a spatially distributed, randomized monitoring network for each study area. Grid wells in COLOR were numbered in the order of sample collection with the prefix "COLOR" (figs. 2-4). Two wells, COLOR-07 and COLOR-18, are located next to the boundary of grid-cells, and water quality in these wells represents that of both cells (fig. 3). With this additional cell coverage, all of the 20 grid cells are considered to be represented in the grid cell network in COLOR.

Additional wells were sampled to evaluate differences in water chemistry between shallow and deep parts of the aquifers, to study the movement of MTBE, and to collect water-quality data in areas where little or no data previously existed. These additional wells are referred to as "understanding wells," and were numbered in the order of sample collection and designated with the prefix "COLORU" (figs.2-3). Understanding wells sampled were not included in the statistical characterization of the water quality in COLOR because including these wells would have caused certain cells to be overrepresented.

Table 1 (all tables are in back of report) provides the GAMA alphanumeric identification number for each well, along with the date sampled, well elevation, and well-construction information. Groundwater samples were collected from 19 public-supply wells, 6 domestic wells, 2 irrigation wells, and 1 industrial well from October through December 2007.

Well locations and identifications were verified using a GPS, 1:24,000-scale USGS topographic map, existing well information in USGS and CDPH databases, and information provided by well owners. Driller's logs for wells were obtained when available. Well information was recorded by hand on field sheets and electronically using specialized software on field laptop computers. All information was verified and then uploaded into the USGS National Water Information System (NWIS). Well owner information is confidential. Well location information and all chemical data are currently inaccessible from NWIS's public website.

The wells in COLOR were sampled for a standard set of constituents, VOCs, pesticides and pesticide degradates, pharmaceutical compounds, perchlorate, 1,2,3-TCP, nutrients, major and minor ions, trace elements, stable isotopes of hydrogen and oxygen in water, carbon isotopes, radioactive constituents (radon-222, radium isotopes, and gross alpha and gross beta radioactivity), and dissolved noble gases. In the Palo Verde area, 1,4-dioxane was collected at all of the Palo Verde study area wells and gasoline oxygenates and degradates were collected at two of the Palo Verde study area wells as part of a special study (table 2).

\section{Sample Collection and Analysis}

Samples were collected in accordance with the protocols established by the USGS National Water Quality Assessment (NAWQA) program (Koterba and others, 1995) and the USGS National Field Manual (U.S. Geological Survey, variously dated). These sampling protocols ensure that a representative sample of groundwater is collected at each site and that potential contamination of samples during collection and handling is minimized. The methods used to collect samples are described in the Appendix section "Sample Collection and Analysis."

Tables 3A-- list the compounds analyzed in each constituent class. Groundwater samples were analyzed for 85 VOCs (table 3A); 8 gasoline oxygenates and degradates (table 3B); 62 pesticides and pesticide degradates (table 3C); 14 pharmaceutical compounds (table 3D); 3 constituents of special interest (table 3E); 5 nutrients (table 3F); 10 major and minor ions and total dissolved solids (table 3G); 25 trace elements (table 3G); arsenic, chromium, and iron species (table $3 \mathrm{H}$ ); stable isotopes of hydrogen and oxygen of water, 7 radioactive constituents, including tritium and carbon- 14 (table 3I); and noble gases and tritium (table 3J). The methods used for sample analysis are described in the Appendix section "Sample Collection and Analysis." 


\section{Data Reporting}

The methods and conventions used for reporting the data are described in the Appendix. More than one method was used at the USGS National Water Quality Laboratory (NWQL) to analyze five constituents in this study: acetone, TAME, DIPE, ETBE, and MTBE (table A2). Only the results from the preferred method are reported; see Appendix section "Constituents on Multiple Analytical Schedules." Arsenic, chromium, and iron concentrations, 1,2,3-TCP concentrations, and tritium activities were measured by more than one laboratory; both sets of laboratory results are reported for these constituents. For field water-quality indicators that were also measured in the laboratory (alkalinity, $\mathrm{pH}$, and specific conductance), the field analyses were preferred, although both sets of results are reported.

\section{Quality Assurance}

The quality-assurance and quality-control procedures used for this study followed the protocols used by the USGS NAWQA program (Koterba and others, 1995) and those described in the USGS National Field Manual (U.S. Geological Survey, variously dated). The quality-assurance plan followed by the NWQL, the primary laboratory used to analyze samples for this study, is described by Maloney (2005) and Pirkey and Glodt (1998). Quality-control (QC) samples collected in the COLOR include source-solution blanks, field blanks, replicates, and matrix and surrogate spikes. QC samples were collected to evaluate potential contamination, and bias and variability of the data that may have resulted from collecting, processing, storing, transporting, and analyzing the samples. Quality-control procedures and qualitycontrol sample results are described in the Appendix section "Quality Assurance."

\section{Water-Quality Results}

\section{Quality-Control Results}

Results of quality-control analyses (blanks, replicates, matrix spikes, and surrogates) were used to evaluate the quality of the data for the groundwater samples. Of the approximately 220 constituents analyzed, 3 were detected in at least 1 field blank. Data from replicates indicated that variability between measurements was generally low; the relative standard deviations (RSDs) were below 5 percent for most replicate analyses. Of the 12 pairs of samples analyzed that had RSDs above the acceptable limit of 20 percent, most had concentrations of constituents near their LRLs, and at these low concentrations, small differences in the measured concentrations in the replicate pairs account for the large
RSDs. Results from analyses of the replicate samples confirm that the procedures used to collect and analyze the samples were consistent. Median matrix-spike recoveries for 14 organic constituents analyzed were lower than the acceptable limits, which may indicate that these constituents might not have been detected in some samples if they were present at very low concentrations. The quality-control results are described in the Appendix section "Quality-Control Results".

\section{Comparison Thresholds}

Concentrations of constituents detected in groundwater samples were compared with CDPH and USEPA regulatory and non regulatory drinking-water health-based thresholds and thresholds established for aesthetic purposes (California Department of Public Health, 2008a,b; U.S Environmental Protection Agency, 2008a,b,c). The chemical composition of treated drinking water may differ from that of untreated groundwater because treated drinking water may be disinfected, filtered, mixed with other waters, and exposed to the atmosphere before being delivered to consumers. Comparisons between concentrations of constituents in raw (untreated) groundwater and drinking-water thresholds are for illustrative purposes only and do not indicate compliance or noncompliance with drinking-water regulations.

The following thresholds were used for comparisons:

- MCL-Maximum Contaminant Level. Legally enforceable standards that apply to public water systems and are designed to protect public health by limiting the levels of contaminants in drinking water. MCLs established by the USEPA are the minimum standards with which states are required to comply, and individual states may choose to set more stringent standards. CDPH has established MCLs for additional constituents not regulated by the USEPA, as well as lowered the threshold concentration for a number of constituents with MCLs established by the USEPA. In this report, a threshold set by the USEPA and adopted by CDPH is labeled "MCL-US" and one set by CDPH that is more stringent than the MCL-US is labeled "MCL-CA." CDPH is notified when constituents are detected at concentrations greater than an MCL-US or MCL-CA thresholds in samples collected for the GAMA Priority Basin Project, but these detections do not constitute violations of CDPH regulations.

- AL-Action Level. Legally enforceable standards that may apply to the public water systems and are designed to protect public health by limiting the levels of copper and lead in drinking water. Detections of copper or lead above the action-level thresholds 
trigger requirements for mandatory water treatment to reduce the corrosive effects of the water to the transfer pipelines. The action levels established by the USEPA and CDPH currently are the same; thus, the thresholds are labeled "AL-US" in this report.

- SMCL_-Secondary Maximum Contaminant Level. Non-enforceable standards applied to constituents that affect the aesthetic qualities of drinking water, such as taste, odor and color, or technical qualities of drinking water, such as scaling and staining. Both the USEPA and CDPH defined SMCLs, but unlike MCLs, SMCLs established by CDPH are not required to be as stringent as those established by USEPA. SMCLs established by CDPH are used in this report (SMCL-CA) for all constituents that have SMCL-CA values. The SMCL-US is used for $\mathrm{pH}$ because no SMCL-CA has been defined.

- NL-Notification Level. Health-based notification levels established by CDPH for some of the constituents in drinking water that lack MCLs (NLCA). If a constituent is detected above its NL-CA, California state law requires timely notification of local governing bodies and recommends consumer notification.

- HAL - Lifetime Health Advisory Level. The maximum concentration of a constituent at which its presence in drinking water is not expected to cause any adverse carcinogenic effects for a lifetime of exposure. HALs are established by the USEPA (HAL-US) and are calculated assuming consumption of 2 liters (2.1 quarts) of water per day over a 70-year lifetime by a 70-kilogram (154-pound) adult and that 20 percent of a person's exposure comes from drinking water.

- RSD5-Risk-Specific Dose. The concentration of a constituent in drinking water corresponding to an excess estimated lifetime cancer risk of 1 in 100,000. RSD5 is an acronym for risk-specific dose at $10^{-5}$. RSD5s are calculated by dividing the $10^{-4}$ cancer risk concentration established by the USEPA by ten (RSD5-US).

For constituents having MCLs, concentrations in groundwater samples were compared to the MCL-US or MCL-CA. Constituents having SMCLs were compared with the SMCL-CA. For chloride, sulfate, specific conductance, and total dissolved solids, CDPH defines a "recommended" and an "upper" SMCL-CA; concentrations of these constituents in groundwater samples were compared with both levels. The SMCL-US for these constituents corresponds with the recommended SMCL-CA. Detected concentrations of constituents that lack an MCL or an SMCL were compared to the NL-CA. For constituents that lack an MCL, SMCL, or NL-CA, detected concentrations were compared with the HAL-US. For constituents that lack an MCL, SMCL, NL-CA, or HAL-US, detected concentrations were compared with the RSD5-US. Note that this hierarchy of selecting comparison thresholds means that for constituents having multiple types of established thresholds, the threshold used for comparison purposes may not be the one with the lowest concentration. The comparison thresholds used in this report are listed in tables 3A-J for all constituents and in tables 4-13 for constituents detected in groundwater samples from COLOR. Not all constituents analyzed for this study have established thresholds. Detections of concentrations of constituents greater than the selected comparison thresholds are marked with asterisks in associated results tables.

\section{Groundwater-Quality Data}

Results from analyses of raw (untreated) groundwater samples collected from COLOR during October through December 2007 are given in tables 4 through 13 . These results tables list only the constituents that were detected and only the samples in which at least one constituent was detected. The tables containing organic constituent classes that were analyzed at all of the grid wells include the number of wells at which each analyte was detected, the frequency at which it was detected (in relation to the number of grid wells), and the total number of constituents detected at each well. Results from the understanding wells are presented in the tables, but these results were excluded from the detection frequency calculations to avoid statistically over-representing the areas near understanding wells.

Table 4 gives water-quality indicators measured in the field and at the NWQL, and tables 5 through 13 present the results of groundwater analyses organized by the compound classes:

- Organic constituents

- Volatile organic compounds VOCs (table 5)

- Gasoline oxygenates and degradates (no detections in the wells for which they were sampled)

- Pesticides and pesticide degradates (table 6)

- Pharmaceuticals (not presented in this report)

- Constituents of special interest (table 7) 
- Inorganic constituents

- Nutrients (table 8)

- Major and minor ions, silica, and total dissolved solids (table 9)

- Trace elements (table 10)

- Arsenic, iron, and chromium speciation (table 11)

- Isotopic tracers, tritium, and carbon-14 (table 12)

- Radioactive constituents (tables 13A,B,C)

Results for pharmaceutical compounds, dissolved noble gases, and tritium helium age dates are not presented in this report; they will be included in subsequent publications.

\section{Field Parameters}

Field and laboratory measurements of dissolved oxygen, water temperature, $\mathrm{pH}$, specific conductance, and alkalinity are given in table 4. Alkalinity and dissolved oxygen are used as indicators of natural processes that affect water chemistry. Specific conductance is a measure of electrical conductivity of water and is proportional to the amount of total dissolved solids (TDS) in the water. Most wells had specificconductance values above the recommended SMCL-CA threshold of $600 \mu \mathrm{S} / \mathrm{cm}$, and many were above the upper threshold of $1,600 \mu \mathrm{S} / \mathrm{cm}$. The $\mathrm{pH}$ value indicates the acidity or basicity of the water. One well had field and laboratory $\mathrm{pH}$ values outside of the SMCL-US range (6.5-8.5) for $\mathrm{pH}$. Laboratory $\mathrm{pH}$ values may differ from field $\mathrm{pH}$ values because the $\mathrm{pH}$ of groundwater may change upon exposure to the atmosphere (see Appendix).

\section{Organic Constituents}

Volatile organic compounds (VOC) can be in paints, solvents, fuels, fuel additives, refrigerants, fumigants, and disinfected water and are characterized by their tendency to evaporate. VOCs generally persist longer in groundwater than in surface water because groundwater is isolated from the atmosphere. Of the 85 VOCs analyzed on Schedule 2020, three were detected in grid well samples; 1,2-Dichloropropane, a fumigant; chloroform, a byproduct of disinfecting drinking water; and 1,2,4-trimethylbenzene, a constituent of gasoline, were detected in grid well samples. All concentrations were below health-based thresholds (table 5). Chloroform is among the most commonly detected VOCs in groundwater nationally (Zogorski and others, 2006), and was detected in 2 grid and 2 understanding wells. MTBE, another constituent of gasoline, was detected in one understanding well. Overall, one or more VOCs were detected in 35 percent of the grid wells. Of the eight VOCs analyzed on Schedule 4024 for gasoline oxygenates and degradates at two understanding wells, COLORU-02 and COLORU-03, none were detected in groundwater samples.

Pesticides include herbicides, insecticides, and fungicides and are used to control weeds, insects, fungi, and other pests in agricultural, urban, and suburban settings. Of the 62 pesticides and pesticide degradates analyzed, five were detected in groundwater samples; all concentrations were below health-based thresholds (table 6). The herbicides atrazine, simazine, and deethylatrazine (a degradate of atrazine) were detected; these pesticides are among those most commonly detected in groundwater nationally (Gilliom and others, 2006). Deethylatrazine was detected in 2 grid wells and 1 understanding well. Atrazine, prometryn, and simazine were detected in one grid well. Terbuthylazine was detected in one understanding well. Overall, one or more pesticides were detected in 20 percent of the grid wells.

\section{Constituents of Special Interest}

Perchlorate and1,2.3-TCP are constituents of special interest in California because they may adversely affect water quality and have recently been found in water supplies (California Department of Public Health, 2008c). Perchlorate was detected in nine grid wells (45 percent) and two understanding wells ( $\underline{\text { table } 7)}$ ). All concentrations were below the MCL-CA. One grid well contained a low concentration of 1,2,3-TCP. 1,4-dioxane was not detected in grid wells or understanding wells.

\section{Inorganic Constituents}

Unlike organic constituents and the constituents of special interest, most inorganic constituents exist naturally in groundwater, although their concentrations may be influenced by human activities.

Nutrients (nitrogen and phosphorus) present in groundwater can affect biological activity in aquifers and in surface-water bodies that receive groundwater discharge. Nitrogen may exist in the form of ammonia, nitrite, or nitrate, depending on the oxidation-reduction state of the groundwater. High concentrations of nitrate can adversely affect human health. All concentrations of nitrate, nitrite, and ammonia measured in samples from COLOR wells were below healthbased thresholds (table 8). 
The major-ion composition, total dissolved solids (TDS) content, and levels of certain trace elements in groundwater affect the aesthetic properties of water, such as taste, color, and odor, and the technical properties, such as scaling and staining. Although no adverse health effects are associated with these properties, they may reduce consumer satisfaction with the water or may have economic effects. CDPH established nonenforceable thresholds (SMCL-CAs) that are based on aesthetic or technical properties rather than health-based concerns for the major ions chloride and sulfate, TDS, and several trace elements. Chloride was detected above the lower SMCL-CA threshold in 7 grid wells and above the upper threshold in 1 grid well (table 9). In understanding wells, chloride was detected above the lower SMCL-CA in 1 well and above the upper threshold in 1 well. Sulfate was detected above the lower SMCL-CA threshold in 10 grid wells and above the upper threshold in 5 grid wells. In understanding wells, sulfate was detected above the lower SMCL-CA in 3 wells and above the upper threshold in 3 wells. TDS was detected above the lower SMCL-CA in 7 grid wells and above the upper threshold in 11 grid wells. In understanding wells, TDS was detected above the lower SMCL-CA threshold in 5 wells and above the upper threshold in 3 wells.

Iron and manganese are trace elements whose concentrations are affected by the oxidation-reduction state of the groundwater. Precipitation of minerals containing iron or manganese may cause orange, brown, or black staining of surfaces. Concentrations of iron above the SMCL-CA was detected in 4 grid wells and 1 understanding well (table 10). Arsenic was detected above the MCL-US threshold in 1 grid well and 1 understanding well. Boron was detected above the NL-CA threshold in 2 grid wells and 1 understanding well. Manganese was detected above the SMCL-CS in 9 grid wells and 6 understanding wells. Molybdenum was detected above the HAL-US threshold in one grid well. Strontium was detected above the HAL-US threshold in two grid wells. Uranium was detected in two grid wells above the MCL-US threshold. Three of the 24 trace elements analyzed in this study, cobalt, lithium, and tungsten, have no health-based thresholds.

Arsenic, iron, and chromium exist in different species, depending on the oxidation-reduction state of the groundwater. The oxidized and reduced species have different solubilities in groundwater and may have different effects on human health. The relative proportions of the oxidized and the reduced species of each element can be used to help interpret the oxidation-reduction state of the aquifer. Concentrations of arsenic, iron, and chromium, and the concentrations of either the reduced or the oxidized species of each element, are reported in table 11. The concentrations of the other species can be calculated by difference. The concentrations of arsenic, iron, and chromium reported in table 11 may be different from those reported in table 10 because different analytical methods were used (see Appendix). The concentrations reported in table 10 are considered to be more accurate and precise.

\section{Isotopic Tracers and Noble Gases}

The isotopic ratios of oxygen and hydrogen of water, the tritium and carbon-14 activities, and the concentrations of dissolved noble gases may be used as tracers of hydrologic processes. The isotopic ratios of hydrogen and oxygen in water (table 12) aid in interpreting the sources of groundwater recharge. These stable-isotope ratios reflect the altitude, latitude, and temperature of precipitation and also the extent of evaporation of the water in surface water bodies or soils before infiltration into the aquifer. Concentrations of dissolved gases are used to estimate the conditions of groundwater recharge, particularly the temperature of the recharge water. Noble-gas analyses were not completed in time to be included in this report; results will be presented in a subsequent publication.

Tritium and carbon-14 activities (table 12), and helium isotope ratios also provide information about the age (time since recharge) of the groundwater. Tritium is a short-lived radioactive isotope of hydrogen that is incorporated into the water molecule. Low levels of tritium are continuously produced by interaction of cosmic radiation with the Earth's atmosphere, and a large amount of tritium was produced as a result of atmospheric testing of nuclear weapons between 1952 and 1963. Thus, concentrations of tritium above background levels usually indicate the presence of water recharged since the early 1950 s. Helium isotope ratios are used in conjunction with tritium concentrations to estimate ages of young groundwater. Helium isotope ratio analyses were not completed in time to be included in this report; results will be presented in a subsequent publication.

Carbon-14 is a radioactive isotope of carbon. Low levels of carbon-14 are continuously produced by interaction of cosmic radiation with the Earth's atmosphere, and incorporated into the atmospheric carbon dioxide. Carbon dioxide dissolves in precipitation, surface water, and groundwater exposed to the atmosphere, thereby entering the hydrologic cycle. Because carbon-14 decays with a half-life of approximately 5,700 years, activities of carbon-14 that are low relative to modern values generally indicate the presence of groundwater that is several thousand years old.

Of the isotopic tracer constituents analyzed for this study, tritium is the only one that has a health-based threshold. All measured tritium activities in samples from COLOR wells were below the MCL-CA (table 12). 


\section{Radioactive Constituents}

Radioactivity is the release of energy or energetic particles during changes in the structure of the nucleus of an atom. Most of the radioactivity in groundwater comes from decay of naturally-occurring isotopes of uranium and thorium that exist in minerals in the sediments or fractured rocks of the aquifer. Both uranium and thorium decay in a series of steps, eventually forming stable isotopes of lead. Radium-226, radium-228, and radon-222 are radioactive isotopes formed during the uranium or thorium decay series. In each step in the decay series, one radioactive element turns into a different radioactive element by emitting an alpha or a beta particle from its nucleus. For example, radium-226 emits an alpha particle and therefore turns into radon-222. Radium-228 decays to form actinium-228 by emitting a beta particle. The alpha and beta particles emitted during radioactive decay are hazardous to human health because these energetic particles may damage cells. Radiation damage to cell DNA increases the risk of getting cancer.

Activity is often used instead of concentration for reporting the presence of radioactive constituents. Activity of radioactive constituents in groundwater is measured in units of picocuries per liter $(\mathrm{pCi} / \mathrm{L})$, and one picocurie is approximately equal to two atoms decaying per minute. The number of atoms decaying is equal to the number of alpha or beta particles emitted.

Most of the COLOR samples analyzed for radioactive constituents had activities of radium and gross alpha and gross beta emitters less than their established healthbased thresholds (tables 13A-C). Three grid wells and one understanding well had gross alpha (72 hour count) activities above the MCL-US of $15 \mathrm{pCi} / \mathrm{L}$. Two grid wells had gross alpha (30 day count) activities above the MCL-US of $15 \mathrm{pCi} / \mathrm{L}$. Activities of radon-222 in samples from 14 grid wells and 5 understanding wells were above the proposed MCL-US of $300 \mathrm{pCi} / \mathrm{L}$, but no samples had an activity that was also above the proposed alternative MCL-US of 4,000 $\mathrm{pCi} / \mathrm{L}$. The proposed alternative MCL-US will apply if the State or local water agency has an approved multimedia mitigation program to address radon levels in indoor air (U.S. Environmental Protection Agency, 1999).

\section{Future Work}

Subsequent reports will be focused on assessing the data presented in this report using a variety of statistical, qualitative, and quantitative approaches to evaluate the natural and human factors affecting groundwater quality in the COLOR. Water-quality data contained in the CDPH and the USGS NWIS databases and water-quality data available from other state and local water agencies will be compiled, evaluated, and used to complement the data in this report; the results of these future efforts will appear in one or more subsequent reports.

\section{Summary}

Groundwater quality in the 188-square-mile Colorado River Study unit (COLOR) was investigated from October through December 2007 as part of the Priority Basin Project of the Groundwater Ambient Monitoring and Assessment (GAMA) Program. The California State Water Resources Control Board (SWRCB), in collaboration with the U.S. Geological Survey (USGS) and the Lawrence Livermore National Laboratory, is implementing the GAMA Program (http://www.waterboards.ca.gov/gama/). The Priority Basin Project was designed by the SWRCB and the USGS in response to the Groundwater Quality Monitoring Act of 2001. The project is a comprehensive assessment of statewide groundwater quality designed to identify and characterize risks to groundwater resources and to increase the availability of public information about groundwater quality. COLOR was the 21 st study unit sampled as part of the project.

COLOR is located in the Desert Hydrogeologic Province, along the Colorado River on the southeastern side of California and is divided into three separate study areas: the Needles Valley, the Palo Verde, and the Yuma Valley. The exterior boundaries of the study areas correspond to the delineated California Department of Water Resources groundwater basins (California Department of Water Resources, 2004a,b,c). The COLOR included assessment of the groundwater quality of samples from 28 wells. Twenty wells were selected using a randomized grid approach to achieve a statistically unbiased representation of groundwater used for public drinking-water supplies. Eight more wells were selected to provide additional sampling density to aid in understanding processes affecting groundwater quality in the region.

Groundwater samples were analyzed for VOCs, pesticides and pesticide degradates, pharmaceutical compounds, perchlorate, 1,2,3-TCP, nutrients, major and minor ions, trace elements, and radioactivity. Naturally occurring isotopes (stable isotopes of hydrogen, oxygen, and carbon, and activities of tritium and carbon-14) and dissolved noble gases also were measured to provide a data set that will be used to help interpret the sources and ages of the sampled groundwater. Gasoline oxygenates and degradates and 1,4-dioxane were also collected in the Palo Verde study area of COLOR. In total, approximately 220 constituents and waterquality indicators were investigated for this study. This report describes the sampling, analytical, and quality assurance used in the study and presents the results of the chemical analyses of the groundwater samples collected during the autumn of 2007 in the COLOR. 
A suite of quality-control samples (blanks, replicates, and matrix spikes) were collected at approximately 30 percent of the wells, and the results for these samples were used to evaluate the quality of the data for the groundwater samples. Field blanks rarely contained detectable concentrations of any constituents, suggesting that contamination during sample collection was not a noticeable source of bias in the data for the groundwater samples. Differences between most replicate samples were within acceptable ranges and matrix spike recoveries were within acceptable ranges for most constituents. Matrix spike recoveries were within acceptable ranges for most constituents.

This study did not attempt to evaluate the quality of water delivered to consumers; water withdrawn from the ground is typically treated, disinfected, and blended with other waters to maintain acceptable water quality. Regulatory thresholds apply to treated water that is served to the consumer, not to raw groundwater. However, to provide some context for the results, concentrations of constituents measured in the raw groundwater were compared with regulatory and nonregulatory health-based thresholds established by the U.S. Environmental Protection Agency (USEPA) and the California Department of Public Health (CDPH).

The concentrations of most constituents detected in groundwater samples from the 20 grid wells and 8 understanding wells in the COLOR were below regulatory and non-regulatory drinking-water thresholds. Specific conductance was the only constituent measured above the lower and upper SMCL-CA thresholds in most wells. All concentrations of VOCs, pesticides, perchlorate, 1, 2, 3-TCP, and nitrate were below established health-based thresholds. The major ion chloride was detected in some wells above the lower and upper SMCL-CA thresholds. Sulfate and total dissolved solids were detected above the lower and upper SMCL-CA thresholds in some wells. Fluoride was detected above the MCL-CA. The trace element arsenic was detected above the MCL-CA, boron was detected above the NL-CA, iron and manganese were detected above their respective SMCL-CAs, molybdenum and strontium were detected above their respective HAL-USs, and uranium was detected above the MCL-US. Radioactive constituents were below healthbased thresholds except gross alpha radioactivity (72-hour count and 30-day count), which was above the MCL-US of 15 $\mathrm{pCi} / \mathrm{L}$, and radon-222, which was above the proposed lower MCL-US of $300 \mathrm{pCi} / \mathrm{L}$ in some samples.

Subsequent reports will present assessment of the data in this report using a variety of statistical, qualitative, and quantitative approaches to assess the natural and human factors affecting groundwater quality.

\section{Acknowledgments}

The authors thank the following cooperators for their support: the State Water Resources Control Board (SWRCB), the California Department of Public Health, the California Department of Water Resources, and Lawrence Livermore National Laboratory. We especially thank the well owners and water purveyors for their generosity in allowing the USGS to collect samples from their wells. Funding for this work was provided by State bonds authorized by Proposition 50 and administered by the SWRCB.

\section{References Cited}

American Public Health Association, 1998, Standard methods for the examination of water and wastewater (20th ed.): Washington, D.C., American Public Health Association, American Water Works Association, and Water Environment Federation, p. 3-37-3-43.

American Society for Testing and Materials, 1998, Annual book of ASTM standards - water and environmental technology: Philadelphia, Pennsylvania, American Society for Testing and Materials, v. 11.02 (Water II), p. 664-666.

Ball, J.W., and McCleskey, R.B., 2003a, A new cationexchange method for accurate field speciation of hexavalent chromium: U.S. Geological Survey Water-Resources Investigations Report 03-4018, $17 \mathrm{p}$.

Ball, J.W., and McCleskey, R.B., 2003b, A new cationexchange method for accurate field speciation of hexavalent chromium: Talanta, v. 61, p. 305-313.

Belitz, Kenneth, Dubrovsky, N.M., Burow, K.R., Jurgens, B.C., and Johnson, Tyler, 2003, Framework for a groundwater quality monitoring and assessment program for California: U.S. Geological Survey Water-Resources Investigations Report 03-4166, 78 p.

Bennett, G.L., V, Belitz, Kenneth, and Milby Dawson, B.J., 2006, California GAMA Program - Groundwater quality data in the northern San Joaquin Basin Study unit, 2005: U.S. Geological Survey Data Series 196, 122 p.

Bishop, C.C., 1963, Geologic map of California, Needles Sheet: California Division of Mines and Geology. Single Map Sheet, Scale 1:250,000. Available at http://ngmdb.usgs. gov/ngm-bin/ILView.pl?sid=41_1.sid\&vtype $=$ b

Burton, C.A., and Belitz, Kenneth, 2008, Groundwater quality data in the southeast San Joaquin Valley, 20052006-Results from the California GAMA Program: U.S. Geological Survey Data Series 351, 103 p. 
California Department of Public Health, 2008a, California drinking water-related laws: Drinking water-related regulations (Title 22) (pdf document), accessed March 1, 2008, at http://www.cdph.ca.gov/certlic/drinkingwater/ Pages/Lawbook.aspx

California Department of Public Health, 2008b, Drinking water notification levels: Notification levels (pdf document), accessed March 1, 2008, at http://www.cdph.ca.gov/certlic/ drinkingwater/Pages/NotificationLevels.aspx

California Department of Public Health, 2008c, Chemicals and contaminants in drinking water, accessed November 11, 2008, at http://www.cdph.ca.gov/certlic/drinkingwater/ Pages/Chemicalcontaminants.aspx

California Department of Water Resources, 1954, Groundwater occurrence and quality, Colorado River Basin Region: Water Quality Investigations Report No. 4.

California Department of Water Resources,1961, Data on water wells in the Dale Valley area, San Bernardino and Riverside Counties, California: California Department of Water Resources Bulletin No. 91-5.

California Department of Water Resources, 1975, California's groundwater: California Department of Water Resources Bulletin 118. $135 \mathrm{p}$.

California Department of Water Resources, 1979, Sources of powerplant cooling water in the desert area of southern California-reconnaissance study: California Department of Water Resources Bulletin 118. 135 p.

California Department of Water Resources, 2003, California's groundwater: California Department of Water Resources Bulletin 118, 246 p., accessed December 1, 2006, at http:// www.groundwater.water.ca.gov/bulletin 118

California Department of Water Resources, 2004a, Needles Valley groundwater basin: California Department of Water Resources Bulletin 118, accessed April 30, 2008, at http://www.dpla2.water.ca.gov/publications/groundwater/ bulletin118/basins/pdfs_desc/7-44.pdf

California Department of Water Resources, 2004b, Palo Verde Mesa groundwater basin: California Department of Water Resources Bulletin 118, accessed April 30, 2008, at http://www.dpla2.water.ca.gov/publications/groundwater/ bulletin118/basins/pdfs_desc/7-39.pdf

California Department of Water Resources, 2004c, Yuma Valley groundwater basin: California Department of Water Resources Bulletin 118, individual basin descriptions, accessed April 30, 2008, at http://www.dpla2.water.ca.gov/ publications/groundwater/bulletin118/basins/pdfs_desc/7$\underline{36 . p d f}$
California Department of Water Resources, 2004d, Palo Verde Mesa groundwater basin: California Department of Water Resources Bulletin 118. Individual basin descriptions, accessed April 30, 2008 at http://www.dpla2.water.ca.gov/ publications/groundwater/bulletin118/basins/pdfs_desc/739.pdf

Childress, C.J.O., Foreman, W.T., Connor, B.F., and Maloney, T.J., 1999, New reporting procedures based on long-term method detection levels and some considerations for interpretations of water-quality data provided by the U.S. Geological Survey National Water Quality Laboratory: U.S. Geological Survey Open-File Report 99-193, 19 p. Available at http://water.usgs.gov/owq/OFR 99-193/ ofr99 193.pdf

Connor, B.F., Rose, D.L., Noriega, M.C., Murtagh, L.K., and Abney, S.R., 1998, Methods of analysis by the U.S. Geological Survey National Water Quality LaboratoryDetermination of 86 volatile organic compounds in water by gas chromatography/mass spectrometry, including detections less than reporting limits: U.S. Geological Survey Open-File Report 97-829, 78 p.

Coplen, T.B., 1994, Reporting of stable hydrogen, carbon, and oxygen isotopic abundances: Pure and Applied Chemistry, v. 66, p. $273-276$.

Coplen, T.B., Hopple, J.A., Böhlke, J.K., Peiser, H.S., Rieder, S.E., Krouse, H.R., Rosman, K.J.R., Ding, T., Vocke, R.D., Jr., Revesz, K.M., Lamberty, A., Taylor, P., and DeBierve, P., 2002, Compilation of minimum and maximum isotope ratios of selected elements in naturally occurring terrestrial materials and reagents: U.S. Geological Survey WaterResources Investigations Report 01-4222, 98 p.

Coplen, T.B., Wildman, J.D., and Chen, J., 1991, Improvements in the gaseous hydrogen-water equilibrium technique for hydrogen isotope analysis: Analytical Chemistry, v. 63, p. 910-912.

Dawson, B.J., Bennett, G.L., V, and Belitz, Kenneth, 2008, California GAMA Program: Ground-water quality data in the Southern Sacramento Valley Study unit, California, 2005-Results from the California GAMA Program: U.S. Geological Survey Data Series 285, 93 p. Available at http:// pubs.usgs.gov/ds/285/index.html

Donahue, D.J., Linick, T.W., and Jull, A.J.T., 1990, Ratio and background corrections for accelerator mass spectrometry radiocarbon measurements: Radiocarbon, v. 32, p. 135-142.

Draper, W.M., Dhoot, J.S., Remoy, J.W., and Perera, S.K., 2000, Trace-level determination of 1,4-dioxane in water by isotopic dilution GC and GC-MS: Analyst, v. 125, p. 1403-1408. 
Eaton, G.F., Hudson, G.B., and Moran, J.E., 2004, Tritiumhelium-3 age-dating of groundwater in the Livermore Valley of California: American Chemical Society ACS Symposium Series, v. 868, p. 235-245.

Epstein, S., and Mayeda, T.K., 1953, Variation of O-18 content of water from natural sources: Geochimica et Cosmochimica Acta, v. 4, p. 213-224.

Faires, L.M., 1993, Methods of analysis by the U.S. Geological Survey National Water Quality LaboratoryDetermination of metals in water by inductively coupled plasma-mass spectrometry: U.S. Geological Survey OpenFile Report 92-634, 28 p.

Ferrari, M.J., Fram, M.S., and Belitz, Kenneth, 2008, Groundwater quality in the central Sierra Study unit, California, 2006: Results from the California GAMA program: U.S. Geological Survey Data Series DS-335, 60 p. Available at http://pubs.usgs.gov/ds/335/index.html

Firestone, R.B., Shirley, V.S., Baglin, C.M., Chu, S.Y.F., and Zipkin, J., 1996, Table of Isotopes ( $8^{\text {th }}$ ed.): New York, John Wiley \& Sons, 3168 p., accessed April 1, 2007, at http:// ie.lbl.gov/toipdf/toi20.pdf

Fishman, M.J., 1993, Methods of analysis by the U.S. Geological Survey National Water Quality LaboratoryDetermination of inorganic and organic constituents in water and fluvial sediments: U.S. Geological Survey OpenFile Report 93-125, 217 p.

Fishman, M.J., and Friedman, L.C., 1989, Methods for determination of inorganic substances in water and fluvial sediments: U.S. Geological Survey Techniques of WaterResources Investigations, book 5, chap. A1, 545 p.

Fram, M.S., and Belitz, Kenneth, 2007, Ground-water quality data in the Southern Sierra Study unit, 2006 - Results from the California GAMA Program: U.S. Geological Survey Data Series 301, 78 p. Available at http://pubs.usgs.gov/ ds/301/index.html

Fram, M.S., Munday, Cathy, and Belitz, Kenneth, 2009, Groundwater quality data for the Tahoe-Martis study unit, 2007: Results from the California GAMA Program: U.S. Geological survey Data-Series 432, 88 p.

Furlong, E.T., Werner, S.L., Anderson, B.D., and Cahill, J.D., 2008, Methods of Analysis by the U.S. Geological Survey National Water Quality Laboratory - Determination of human-health pharmaceuticals in filtered water by chemically modified styrene-divinylbenzene resin-based sold-phase extraction and high-performance liquid chromatography/mass spectrometry: U.S. Geological Survey Techniques and Methods, book 5, chap. A9, 56 p.
Garbarino, J.R., 1999, Methods of analysis by the U.S. Geological Survey National Water Quality LaboratoryDetermination of dissolved arsenic, boron, lithium, selenium, strontium, thallium, and vanadium using inductively coupled plasma-mass spectrometry: U.S. Geological Survey Open-File Report 99-093, 31 p.

Garbarino, J.R., and Damrau, D.L., 2001, Methods of analysis by the U.S. Geological Survey National Water Quality Laboratory-Determination of organic plus inorganic mercury in filtered and unfiltered natural water with cold vapor-atomic fluorescence spectrometry: U.S. Geological Survey Water-Resources Investigations Report 01-4132, $16 \mathrm{p}$.

Garbarino, J.R., Kanagy, J.R., and Cree, M.E., 2006, Determination of elements in natural-water, biota, sediment, and soil samples using collision/reaction cell inductively coupled plasma-mass spectrometry: U.S. Geological Survey Techniques and Methods, book 5, chap. B1, 88 p.

Gilliom, R.J., Barbash, J.E., Crawford, C.G., Hamilton, P.A., Martin, J.D., Nakagaki, N., Nowell, L.H., Scott, J.C., Stackelberg, P.E., Thelin, G.P., and Wolock, D.M., 2006, The quality of our nation's waters: Pesticides in the nation's streams and groundwater, 1992-2001: U.S. Geological Survey Circular 1291, 172 p.

Goldrath, D.A, Wright, M.T., and Belitz, Kenneth, 2009, Ground-water quality data in the Coachella Valley study unit, 2007: Results from the California GAMA Program: U.S. Geological Survey Data Series 373, 70 p. Available at http://pubs.usgs.gov/ds/373/index.html

Gran, G., 1952, Determination of the equivalence point in potentiometric titration, Part II: Analyst, v. 77, p. 661-671.

Grob, R.L, ed., 1995, Modern practice of gas chromatography ( $3^{\text {rd }}$ ed.): New York, John Wiley \& Sons, 888 p.

Hahn, G. J., Meeker, W. Q., 1991, Statistical intervals: a guide for practitioners: New York, John Wiley \& Sons, Inc. 392 p.

Hamlin, S.N., Belitz, Kenneth, Kraja, S., and Dawson, B.J., 2002, Groundwater quality in the Santa Ana watershed, California: Overview and data summary: U.S. Geological Survey Water-Resources Investigations Report 02-4243, $137 \mathrm{p}$.

Hely, A.G., and Peck, E.L, 1964, Precipitation, runoff and water loss in the lower Colorado River-Salton Sea area: U.S. Geophysics Paper, 486-B.

Hutson, S.S., Barber, N.L., Kenny, J.F., Linsey, K.S., Lumia, D.S., and Maupin, M.A., 2004, Estimated use of water in the United States in 2000: U.S. Geological Survey Circular $1268,46 \mathrm{p}$. 
Jennings, C.W., 1967, Geologic map of California, Salton Sea Sheet: Single map sheet, Scale 1:250,000.

Jull, A.J.T., Burr, G.S., McHargue, L.R., Lange, T.E., Lifton, N.A., Beck, J.W., Donahue, D.J., and Lal, D., 2004, New frontiers in dating of geological, paleoclimatic, and anthropological applications using accelerator mass spectrometric measurements of ${ }^{14} \mathrm{C}$ and $\mathrm{Be}$ in diverse samples: Global and Planetary Change, v. 41, p. 309-323.

Kent, Robert, and Belitz, Kenneth, 2009, Ground-water quality data in the Upper Santa Ana Watershed Study Unit, November 2006 to March 2007: Results from the California GAMA Program: U.S. Geological Survey Data-Series 404, 116 p. Avilable at http://pubs.usgs.gov/ds/404/index.html

Kolpin, D.W., Furlong, E.T., Meyer, M.T., Thurman, E.M., Zaugg, S.D., Barber, L.B., and Buxton, H.T., 2002, Pharmaceuticals, hormones and other organic wastewater contaminants in U.S. streams, 1999-2000: Environmental Science \& Technology, v. 36, no. 6, p. 1202-1211.

Koterba, M.T., Wilde, F.D., and Lapham, W.W., 1995, Groundwater data-collection protocols and procedures for the National Water-Quality Assessment ProgramCollection and documentation of water-quality samples and related data: U.S. Geological Survey Open-File Report 95-399, $113 \mathrm{p}$.

Krieger, H.L., and Whittaker, E.L., 1980, Prescribed procedures for measurement of radioactivity in drinking water: U.S. Environmental Protection Agency EPA-6004-80-032, 142 p. Available from the National Technical Information Service at http://www.ntis.gov as PB80224744 .

Kulongoski, J.T., and Belitz, Kenneth, 2004, Groundwater ambient monitoring and assessment program: U.S. Geological Survey Fact Sheet 2004-3088, 2 p.

Kulongoski, J.T., and Belitz, Kenneth, 2007, Ground-water quality data in the Monterey Bay and Salinas Valley Basins, California, 2005-Results from the California GAMA Program: U.S. Geological Survey Data Series 258, 84 p. Available at http://pubs.usgs.gov/ds/2007/258/index.html

Kulongoski, J.T., Belitz, Kenneth, and Dawson, B.J., 2006, Groundwater quality data in the North San Francisco Bay hydrogeologic provinces, California, 2004: Results from the California Ground-Water Ambient Monitoring and Assessment (GAMA) Program: U.S. Geological Survey Data Series 167, 100 p.

Land, M.K., and Belitz, Kenneth, 2008, Ground-water quality data in the San Fernando-San Gabriel study unit, 2005-Results from the California GAMA Program: U.S. Geological Survey Data Series 356, 84 p. Available at http:// pubs.usgs.gov/ds/356/
Landon, M.K., and Belitz, Kenneth, 2008, Ground-water quality data in the Central Eastside San Joaquin Basin 2006: Results from the California GAMA Program: U.S. Geological Survey Data Series 325, 88 p. Available at http:// pubs.usgs.gov/ds/325/

Lane, S.L., Flanagan, S., and Wilde, F.D., 2003, Selection of equipment for water sampling (ver. 2.0): U.S. Geological Survey Techniques of Water-Resources Investigations, book 9, chap. A2, accessed June 28, 2007, at http://pubs.water. usgs.gov/twri9A2/

Lewis, M.E., 2006, Dissolved oxygen (ver. 2.1): U.S. Geological Survey Techniques of Water-Resources Investigations, book 9, chap. A6.2, accessed June 28, 2007 , at http://pubs.water.usgs.gov/twri9A6.2/

Lindley, C.E., Stewart, J.T., and Sandstrom, M.W., 1996, Determination of low concentrations of acetochlor in water by automated solid-phase extraction and gas chromatography with mass selective detection: Journal of AOAC International, v. 79, no. 4, p. 962-966.

Madsen, J.E., Sandstrom, M.W., and Zaugg, S.D., 2003, Methods of analysis by the U.S. Geological Survey National Water Quality Laboratory-A method supplement for the determination of fipronil and degradates in water by gas chromatography/mass spectrometry: U.S. Geological Survey Open-File Report 02-462, 11 p.

Maloney, T.J., ed., 2005, Quality management system, U.S. Geological Survey National Water Quality Laboratory: U.S. Geological Survey Open-File Report 2005-1263, accessed April 1, 2007 at http://pubs.usgs.gov/of/2005/1263/pdf/ OFR2005-1263.pdf

Mathany, T.M. and Belitz, Kenneth, 2009, Groundwater quality data in the Mojave Study Unit, 2008: Results from the California GAMA Program: U.S. Geological Survey Data-Series 440, 80 p. Available at http://pubs.usgs.gov/ $\underline{\mathrm{ds} / 440 /}$

Mathany, T.M., Land, Michael, and Belitz, Kenneth, 2008, Ground-water quality data in the Coastal Los Angeles Basin Study Unit, 2006-Results from the California GAMA Program: U.S. Geological Survey Data Series 387, 98 p. Available at http://pubs.usgs.gov/ds/387/

McCleskey, R.B., Nordstrom, D.K., and Ball, J.W., 2003, Metal interferences and their removal prior to the determination of $\mathrm{As}(\mathrm{T})$ and $\mathrm{As}(\mathrm{III})$ in acid mine waters by hydride generation atomic absorption spectrometry: U.S. Geological Survey Water-Resources Investigations Report 03-4117, 14 p. Available at http://pubs.usgs.gov/wri/wri034117/WRI034117.pdf 
McCurdy, D.E., Garbarino, J.R., and Mullin, A.H., 2008, Interpreting and reporting radiological water-quality data: U.S. Geological Survey Techniques and Methods, book 5, chap. B6, 33 p.

McLain, B., 1993, Methods of analysis by the U.S. Geological Survey National Water Quality Laboratory-Determination of chromium in water by graphite furnace atomic absorption spectrophotometry: U.S. Geological Survey Open-File Report 93-449, 16 p.

Metzger, D.G., and Loeltz, O.J., 1973, Geohydrology of the Needles Area, Arizona, California, and Nevada: U.S. Geological Professional Paper 486-J.

Montrella, Joseph, and Belitz, Kenneth, 2009, Ground-water quality data in the Santa Clara River Valley study unit, 2007: Results from the California GAMA Program: U.S. Geological Survey Data Series 408, 84 p. Available at http:// pubs.usgs.gov/ds/408/

Moran, J.E., Hudson, G.B., Eaton, G.F., and Leif, R., 2002, A contamination vulnerability assessment for the Livermore-Amador and Niles Cone Groundwater Basins: UCRL-AR-148831, 25 p.

National Climate Data Center, 2008, Annual mean total precipitation: National Oceanic and Atmospheric Administration, accessed April 30, 2008, at http://www. ncdc.noaa.gov/oa/climateresearch.html

Okamoto, H.S., Steeber, W.R., Remoy, R., Hill P., and Perera, S.K., eds., 2002, Determination of 1,2,3-trichloropropane in drinking water by purge and trap gas chromatography/ mass spectrometry (February 2002): California Department of Health Services, Division of Drinking Water and Environmental Management, Sanitation and Radiation Laboratories Branch, accessed August 21, 2008, at http:// www.cdph.ca.gov/certlic/drinkingwater/Documents/ Drinkingwaterlabs/TCPbyPT-GCMS.pdf

Olmsted, F.H., Joeltz, O.J., and Irelan, B., 1973, Geohydrology of the Yuma area, Arizona and California: U.S. Geological Survey Professional Paper 486-H, 227 p.

Olsen, L.D., Fram, M.S., and Belitz, Kenneth, 2010, Review of trace element field blank data collected for the California Groundwater Ambient Monitoring and Assessment (GAMA) Program, May 2004-January 2008: U.S. Geological Survey Scientific Investigations Report 2009-5220, $58 \mathrm{p}$.

Patton, C.J., and Kryskalla, J.R., 2003, Methods of analysis by the U.S. Geological Survey National Water Quality Laboratory-Evaluation of alkaline persulfate digestion as an alternative to Kjeldahl digestion for determination of total and dissolved nitrogen and phosphorous in water: U.S. Geological Survey Water-Resources Investigations Report 03-4174, $33 \mathrm{p}$.
Pirkey, K.D., and Glodt, S.R., 1998, Quality control at the U.S. Geological Survey National Water Quality Laboratory: U.S. Geological Survey Fact-Sheet 026-98, 4 p. Available at http://pubs.er.usgs.gov/usgspubs/fs/fs02698

Pyke, C.B., 1972, Some meteorological aspects of the seasonal distribution of precipitation in the western United States and Baja California: Contrib 193, University of California Water Resources Center, Los Angeles.

Radtke, D.B., Davis, J.V., and Wilde, F.D., 2005, Specific electrical conductance (ver. 1.2): U.S. Geological Survey Techniques of Water-Resources Investigations, book 9, chap. A6.3, accessed June 28, 2007, at http://pubs. water. usgs.gov/twri9A6.3/

Ray, M.C., Kulongoski, J.T., and Belitz, Kenneth, 2009, Ground-water quality data in the San Francisco Bay study unit, 2007: Results from the California GAMA program: U.S. Geological Survey Data Series 396, 92 p. Available at http://pubs.usgs.gov/ds/396/

Rose, D.L., and Sandstrom, M.W., 2003, Methods of analysis by the U.S. Geological Survey National Water Quality Laboratory-Determination of gasoline oxygenates, selected degradates, and BTEX in water by heated purge and trap/gas chromatography/mass spectrometry: U.S. Geological Survey Water-Resources Investigations Report 03-4079, $31 \mathrm{p}$.

Rounds, S.A., 2006, Alkalinity and acid neutralizing capacity (ver. 3): U.S. Geological Survey Techniques of WaterResources Investigations, book 9, chap. A6.6, accessed February 5, 2008, at http://pubs.water.usgs.gov/twri9A6.6/

Sandstrom, M.W., Stroppel, M.E., Foreman, W.T., and Schroeder, M.P., 2001, Methods of analysis by the U.S. Geological Survey National Water Quality LaboratoryDetermination of moderate-use pesticides and selected degradates in water by C-18 solid-phase extraction and gas chromatography/mass spectrometry: U.S. Geological Survey Water-Resources Investigations Report 01-4098, $70 \mathrm{p}$.

Schmitt, S.J., Fram, M.S., Milby Dawson, B.J., Belitz, Kenneth, 2008, Ground-water quality data in the middle Sacramento Valley study unit, 2006-Results from the California GAMA program: U.S. Geological Survey Data Series 385, 100 p. Available at http://pubs.usgs.gov/ds/385/

Scott, J.C., 1990, Computerized stratified random site selection approaches for design of a groundwater quality sampling network: U.S. Geological Survey Water-Resources Investigations Report 90-4101, 109 p. 
Shelton, J.L., Burow, K.R., Belitz, Kenneth, Dubrovsky, N.M., Land, M.T., and Gronberg, J.M., 2001, Low-level volatile organic compounds in active public supply wells as groundwater tracers in the Los Angeles physiographic basin, California, 2000: U.S. Geological Survey Water-Resources Investigations Report 01-4188. 29 p.

Shelton, J.L., Pimentel, I., Fram, M.S., Belitz, Kenneth, 2008, Ground-water quality in the Kern County Subbasin Study unit, 2006-Results from the California GAMA Program: U.S. Geological Survey Data Series 337, 75 p. Available at http://pubs.usgs.gov/ds/337/

State of California, State Water Resources Control Board, 2003, Report to the Governor and Legislature, A comprehensive groundwater quality monitoring program for California: Assembly Bill 599, March 2003, 100 p. Available at http://www.waterboards.ca.gov/gama/docs/ final ab 599 rpt to legis 7 31_03.pdf

Stookey, L.L., 1970, FerroZine-A new spectrophotometric reagent for iron: Analytical Chemistry, v. 42, p. 779-781.

Stumm, W., and Morgan, J.J., 1996, Aquatic Chemistry: Chemical equilibria and rates in natural waters, $3^{\text {rd }}$ ed.: New York, John Wiley \& Sons, 1022 p.

Thatcher, L.L., Janzer, V.J., and Edwards, K.W., 1977, Methods for the determination of radioactive substances in water: U.S. Geological Survey Techniques of WaterResources Investigations, book 5, chap. A5, 95 p.

Timme, P.J., 1995, National Water Quality Laboratory 1995 services catalog: U.S. Geological Survey Open-File Report 95-352, $120 \mathrm{p}$.

To, T.B., Nordstrom, D.K., Cunningham, K.M., Ball, J.W., and McCleskey, R.B., 1998, New method for the direct determination of dissolved $\mathrm{Fe}$ (III) concentration in acid mine waters: Environmental Science and Technology, v. 33, p. 807-813.

U.S. Environmental Protection Agency, 1995, Method 524.2, Measurement of purgeable organic compounds in water by capillary column gas chromatography/mass spectrometry: U.S. Environmental Protection Agency EPA/600/R-95-131. Available at http://www.nemi.gov/

U.S. Environmental Protection Agency, 1996, Method $8270 \mathrm{C}$ - Semivolatile organic compounds by gas chromatography/mass spectrometry (rev. 3). Available at http://www.nemi.gov/

U.S. Environmental Protection Agency, 1999, National Primary Drinking Water Regulations, Radon-222: Federal Register, v. 64, no. 211, p. 59,245-59,294.
U.S. Environmental Protection Agency, 2002, Guidelines for establishing procedures for the analysis of pollutants: U.S. Code of Federal Regulations, Title 40,136 p.

U.S. Environmental Protection Agency, 2005, Method 331.0Determination of perchlorate in drinking water by liquid chromatography electrospray ionization mass spectrometry (Revision 1.0, January 2005): Office of Groundwater and Drinking Water, EPA Document \# 815-R-05-007, 34 p., accessed August 21, 2008, at http://www.epa.gov/safewater/ methods/pdfs/methods/met331 0.pdf

U.S. Environmental Protection Agency, 2008a, Drinking water contaminants, accessed March 1, 2008, at http://www.epa. gov/safewater/contaminants/index.html

U.S. Environmental Protection Agency, 2008b, Drinking water health advisories: 2006 Drinking water standards and health advisory tables (pdf document), accessed March 1, 2008, at http://www.epa.gov/waterscience/criteria/drinking/\#dwstandards

U.S. Environmental Protection Agency, 2008c, Proposed radon in drinking water rule, accessed March 1, 2008, at http://www.epa.gov/safewater/radon/proposal.html

U.S. Geological Survey, variously dated, National field manual for the collection of water-quality data: U.S. Geological Survey Techniques of Water-Resources Investigations, book 9, chap. A1-A9, accessed June 28, 2007, at http:// water.usgs.gov/owq/FieldManual/

Weiss, R.F., 1968, Piggyback sampler for dissolved gas studies on sealed water samples: Deep Sea Research, v. 15, p. 721-735.

Wilde, F.D., ed., 2004, Cleaning of equipment for water sampling (ver. 2.0): U.S. Geological Survey Techniques of Water-Resources Investigations, book 9, chap. A3, accessed June 28, 2007, at http://pubs.water.usgs.gov/twri9A3/

Wilde, F.D., 2006, Temperature (ver. 2): U.S. Geological Survey Techniques of Water-Resources Investigations, book 9, chap. A6.1, accessed June 28, 2007, at http://pubs. water.usgs.gov/twri9A6.1/

Wilde, F.D., Busenberg, E., and Radtke, D.B., 2006, pH (ver. 1.3): U.S. Geological Survey Techniques of WaterResources Investigations, book 9, chap. A6.4, accessed June 28, 2007, at http://pubs.water.usgs.gov/twri9A6.4/

Wilde, F.D., and Radtke, D.B., 2005, General information and guidelines (ver. 1.2): U.S. Geological Survey Techniques of Water-Resources Investigations, book 9, chap. A6.0, accessed June 28, 2007, at http://pubs.water.usgs.gov/ twri9A6.0/ 
Wilde, F.D., Radtke, D.B., Gibs, J., and Iwatsubo, R.T., 1999, Collection of water samples: U.S. Geological Survey Techniques of Water-Resources Investigations, book 9, chap. A4, accessed June 28, 2007, at http://pubs.water.usgs. gov/twri9A4/

Wilde, F.D., Radtke, D.B., Gibs, J., and Iwatsubo, R.T., 2004, Processing of water samples: U.S. Geological Survey Techniques of Water-Resources Investigations, book 9, chap. A5, accessed June 28, 2007, at http://pubs.water.usgs. gov/twri9A5/

Wright, M.T., Belitz, Kenneth, and Burton, C.A., 2005, California GAMA program - Groundwater quality in the San Diego drainages hydrologic province, California, 2004: U.S. Geological Survey Data Series 129, 91 p. Available at http://pubs.usgs.gov/ds/2005/129/
Zaugg, S.D., Sandstrom, M.W., Smith, S.G., and Fehlberg, K.M., 1995, Methods of Analysis by the U.S. Geological Survey National Water Quality Laboratory-Determination of pesticides in water by $\mathrm{C}-18$ solid-phase extraction and capillary-column gas chromatography/mass spectrometry: U.S. Geological Survey Open-File Report 95-181, 60 p.

Zogorski, J.S., Carter, J.M., Ivahnenko, T., Lapham, W.W., Moran, M.J., Rowe, B.L., Squillace, P.J., and Toccalino, P.L., 2006. Volatile organic compounds in the Nation's groundwater and drinking-water supply wells: U.S. Geological Survey Circular 1292, 101 p. 
22 Groundwater-Quality Data in the Colorado River Study Unit, 2007: Results from the California GAMA Program

\section{Tables}


Table 1. Well identification and sampling and construction information for wells sampled for the Colorado River Groundwater Ambient Monitoring and Assessment (GAMA) study, California, autumn 2007.

[GAMA well identification number: COLOR, Colorado River study unit grid well; COLORU, Colorado River study unit understanding well. Elevation of LSD. Land-surface datum (LSD) is a datum plane that is approximately at land surface at each well. The elevation of the LSD is described in feet above the North American Vertical Datum 1988. Other abbreviations: ft, foot; NAVD 88, North American Vertical Datum 1988; na, not available]

\begin{tabular}{|c|c|c|c|c|c|}
\hline \multirow{2}{*}{$\begin{array}{c}\text { GAMA well } \\
\text { identification } \\
\text { number }\end{array}$} & \multicolumn{2}{|c|}{ Sampling information } & \multicolumn{3}{|c|}{ Construction information } \\
\hline & Date & $\begin{array}{c}\text { Elevation of LSD } \\
\text { (ft above NAVD 88) }\end{array}$ & $\begin{array}{c}\text { Well depth } \\
\text { (ft below LSD) }\end{array}$ & $\begin{array}{l}\text { Top of opening } \\
\text { (ft below LSD) }\end{array}$ & $\begin{array}{l}\text { Bottom of opening } \\
\text { (ft below LSD) }\end{array}$ \\
\hline \multicolumn{6}{|c|}{ Grid wells } \\
\hline COLOR-01 & $10 / 01 / 2007$ & 327 & na & na & na \\
\hline COLOR-02 & $10 / 01 / 2007$ & 176 & na & na & na \\
\hline COLOR-03 & $10 / 02 / 2007$ & 132 & 512 & 437 & 497 \\
\hline COLOR-04 & $10 / 03 / 2007$ & 232 & 90 & 30 & 90 \\
\hline COLOR-05 & $10 / 22 / 2007$ & 272 & 610 & 380 & 590 \\
\hline COLOR-06 & $10 / 24 / 2007$ & 269.21 & 505 & na & na \\
\hline COLOR-07 & $10 / 25 / 2007$ & 258 & 438 & 20 & 438 \\
\hline COLOR-08 & $11 / 01 / 2007$ & 390.73 & 500 & 140 & 480 \\
\hline COLOR-09 & $11 / 05 / 2007$ & 332 & na & na & na \\
\hline COLOR-10 & $11 / 06 / 2007$ & 245 & 1,000 & na & na \\
\hline COLOR-11 & $11 / 07 / 2007$ & 242 & na & na & na \\
\hline COLOR-12 & $11 / 26 / 2007$ & 732 & 420 & 300 & 420 \\
\hline COLOR-13 & $11 / 27 / 2007$ & 575.23 & 195 & na & 195 \\
\hline COLOR-14 & $11 / 28 / 2007$ & 252 & na & na & na \\
\hline COLOR-15 & $11 / 29 / 2007$ & 139 & na & na & na \\
\hline COLOR-16 & $12 / 10 / 2007$ & 281 & 600 & 378 & 382 \\
\hline COLOR-17 & $12 / 11 / 2007$ & 532 & 210 & 80.2 & 200 \\
\hline COLOR-18 & $12 / 12 / 2007$ & 337 & 600 & 150 & 400 \\
\hline COLOR-19 & $12 / 17 / 2007$ & 137.7 & 143 & 118 & 140 \\
\hline COLOR-20 & $12 / 18 / 2007$ & 907 & 700 & na & na \\
\hline \multicolumn{6}{|c|}{ Understanding wells } \\
\hline$\overline{\text { COLORU-01 }}$ & $10 / 04 / 2007$ & 279 & 492 & 292 & 492 \\
\hline COLORU-02 & $10 / 23 / 2007$ & 267.19 & 454 & 436 & na \\
\hline COLORU-03 & $10 / 23 / 2007$ & 267.21 & 335 & 310 & 335 \\
\hline COLORU-04 & $10 / 29 / 2007$ & 477 & 240.5 & 54 & 160 \\
\hline COLORU-05 & $10 / 30 / 2007$ & 477 & 105 & 38 & 82 \\
\hline COLORU-06 & $10 / 31 / 2007$ & 408 & 500 & 160 & 480 \\
\hline COLORU-07 & $11 / 06 / 2007$ & 232 & 130 & na & na \\
\hline COLORU-08 & $12 / 20 / 2007$ & 260 & na & na & na \\
\hline
\end{tabular}


Table 2. Classes of chemical constituents and water-quality indicators collected for the Colorado River Groundwater Ambient Monitoring and Assessment (GAMA) study, California, autumn 2007.

\begin{tabular}{|c|c|c|}
\hline Analyte classes & $\begin{array}{l}\text { Analyte } \\
\text { list table }\end{array}$ & $\begin{array}{c}\text { Results } \\
\text { table }\end{array}$ \\
\hline \multicolumn{3}{|c|}{ Water-quality indicators } \\
\hline Dissolved oxygen, temperature, specific conductance & No table & $\underline{4}$ \\
\hline $\mathrm{pH}$, alkalinity & No table & $\underline{4}$ \\
\hline \multicolumn{3}{|c|}{ Organic constituents } \\
\hline Volatile organic compounds & $\underline{3 \mathrm{~A}}$ & $\underline{5}$ \\
\hline Gasoline oxygenates and degradates ${ }^{1}$ & $\underline{3 \mathrm{~B}}$ & None detected \\
\hline Pesticides and pesticide degradates & $\underline{3 \mathrm{C}}$ & $\underline{6}$ \\
\hline Pharmaceutical compounds & $\underline{3 \mathrm{D}}$ & No table ${ }^{2}$ \\
\hline \multicolumn{3}{|c|}{ Constituents of special interest } \\
\hline Perchlorate & $\underline{3 \mathrm{E}}$ & $\underline{7}$ \\
\hline 1,2,3-Trichloropropane & $\underline{3 \mathrm{E}}$ & $\underline{7}$ \\
\hline 1,4 Dioxane $^{3}$ & $\underline{\underline{3 E}}$ & $\underline{7}$ \\
\hline \multicolumn{3}{|c|}{ Inorganic constituents } \\
\hline Nutrients & $\underline{3 \mathrm{~F}}$ & $\underline{8}$ \\
\hline Major and minor ions and trace elements & $\underline{3 \mathrm{G}}$ & $\underline{9,10}$ \\
\hline Arsenic, chromium, and iron abundances and speciation ${ }^{4}$ & $\underline{\underline{3 H}}$ & $\underline{11}$ \\
\hline \multicolumn{3}{|c|}{ Stable isotopes } \\
\hline Stable isotopes of hydrogen and oxygen of water & $\underline{3 \mathrm{I}}$ & $\underline{11}$ \\
\hline Stable isotopes of carbon and carbon-14 abundance & $\underline{3 \mathrm{I}}$ & $\underline{11}$ \\
\hline \multicolumn{3}{|c|}{ Radioactivity and noble gases } \\
\hline Tritium & $\underline{3 I}$ & $\underline{12}$ \\
\hline Radium isotopes & $\underline{3 I}$ & $\underline{13 \mathrm{~A}}$ \\
\hline Gross alpha and gross beta radioactivity & $\underline{3 I}$ & $\underline{13 \mathrm{~B}}$ \\
\hline Radon-222 & $\underline{3 I}$ & $\underline{13 \mathrm{C}}$ \\
\hline Noble gases & $\underline{3 \mathrm{~J}}$ & No table ${ }^{2}$ \\
\hline
\end{tabular}

\footnotetext{
${ }^{1}$ Collected in two wells in the Palo Verde Valley study area.

${ }^{2}$ Samples were collected but not analyzed; data will be presented in subsequent publications.

${ }^{3}$ Collected in the Palo Verde Valley study area only.

${ }^{4}$ Arsenic and iron abundances and speciation samples were collected at 27 of 28 wells.
} 
Table 3A. Volatile organic compounds, primary uses or sources, comparative thresholds, and reporting information for the U.S. Geological Survey (USGS) National Water Quality Laboratory Schedule 2020.

[The five-digit USGS parameter code is used to uniquely identify a specific constituent or property. Threshold types and threshold levels as of December 20, 2007. Threshold type: HAL-US, U.S. Environmental Protection Agency lifetime health advisory level; MCL-CA, California Department of Public Health maximum contaminant level; MCL-US, U.S. Environmental Protection Agency maximum contaminant level; NL-CA, California Department of Public Health notification level; RSD5-US, U.S. Environmental Protection Agency risk specific dose at a risk factor of $10^{-5}$. Other abbreviations: CAS, Chemical Abstract Service; LRL, laboratory reporting level; THM, trihalomethane; D, detected in groundwater samples (table 5); na, not available; $\mu \mathrm{g} / \mathrm{L}$, microgram per liter; -, not detected]

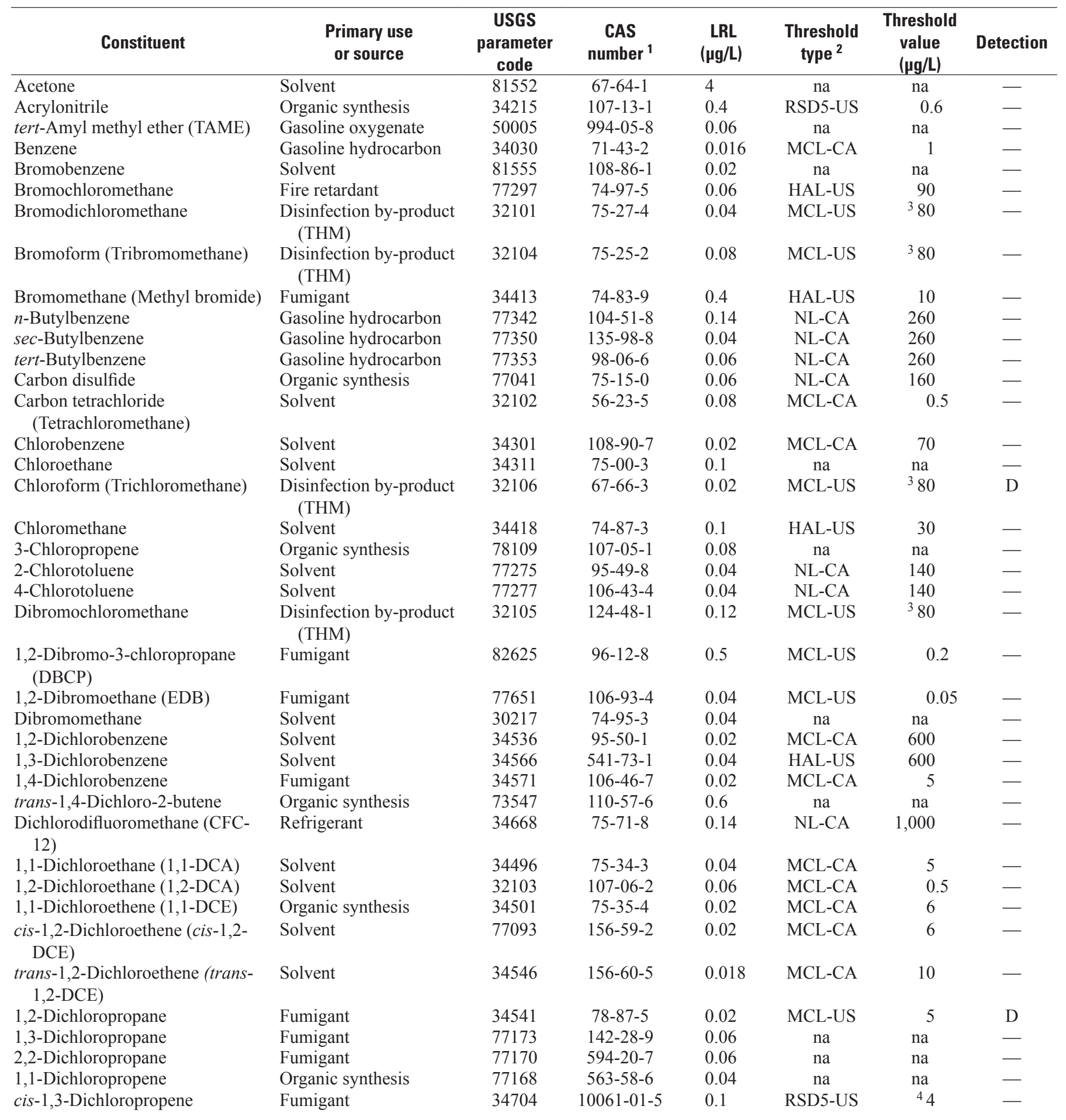


Table 3A. Volatile organic compounds, primary uses or sources, comparative thresholds, and reporting information for the U.S. Geological Survey (USGS) National Water Quality Laboratory Schedule 2020.-Continued

[The five-digit USGS parameter code is used to uniquely identify a specific constituent or property. Thresholds and threshold values as of December $20,2007$. Threshold type: HAL-US, U.S. Environmental Protection Agency lifetime health advisory level; MCL-CA, California Department of Public Health maximum contaminant level; MCL-US, U.S. Environmental Protection Agency maximum contaminant level; NL-CA, California Department of Public Health notification level; RSD5-US, U.S. Environmental Protection Agency risk specific dose at a risk factor of $10^{-5}$. Other abbreviations: CAS, Chemical Abstract Service; LRL, laboratory reporting level; THM, trihalomethane; D, detected in groundwater samples (table 5); na, not available; $\mu \mathrm{g} / \mathrm{L}$, microgram per liter; -, not detected]

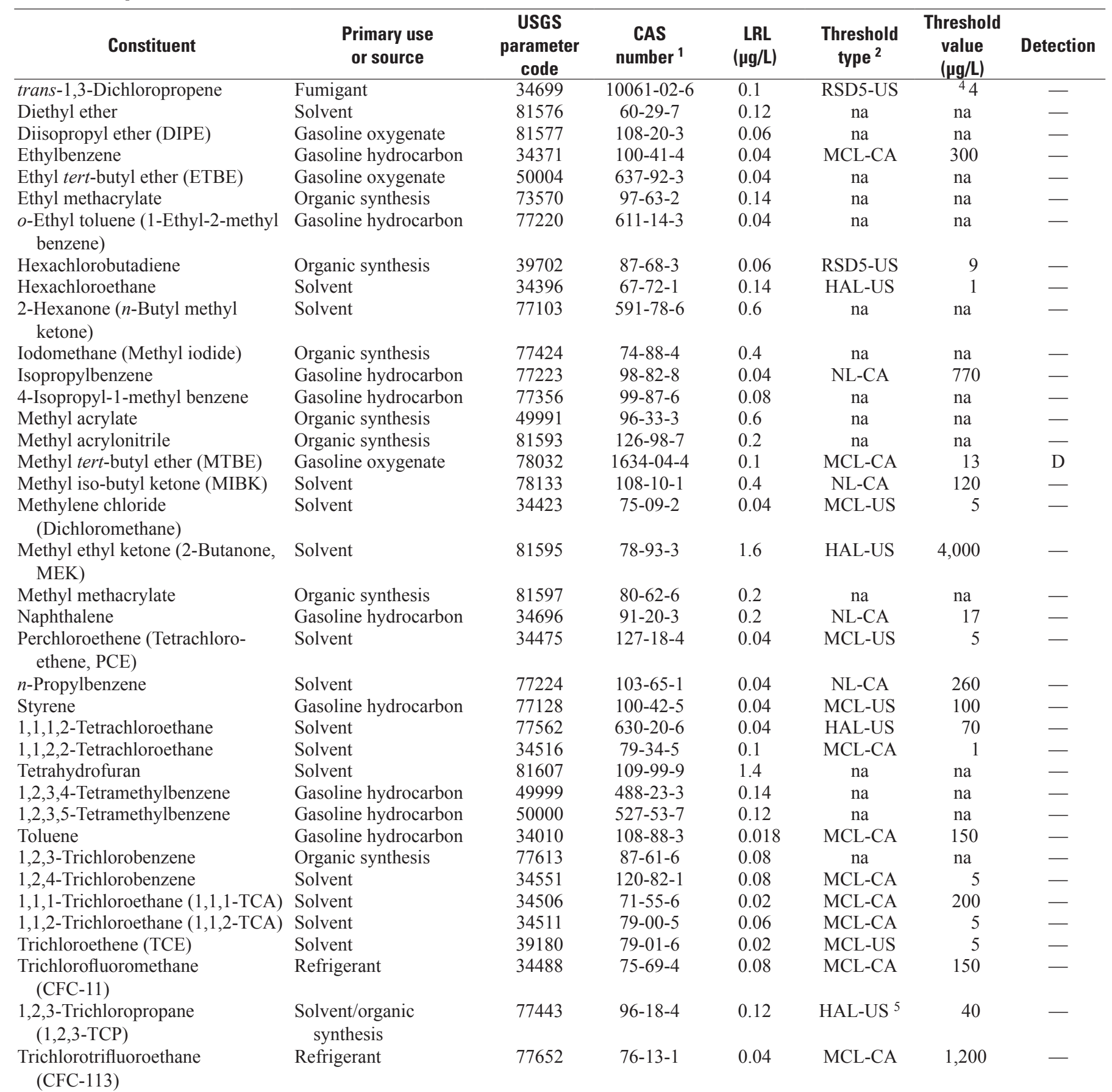


Table 3A. Volatile organic compounds, primary uses or sources, comparative thresholds, and reporting information for the U.S. Geological Survey (USGS) National Water Quality Laboratory Schedule 2020.-Continued

[The five-digit USGS parameter code is used to uniquely identify a specific constituent or property. Thresholds and threshold values as of December $20,2007$. Threshold type: HAL-US, U.S. Environmental Protection Agency lifetime health advisory level; MCL-CA, California Department of Public Health maximum contaminant level; MCL-US, U.S. Environmental Protection Agency maximum contaminant level; NL-CA, California Department of Public Health notification level; RSD5-US, U.S. Environmental Protection Agency risk specific dose at a risk factor of $10^{-5}$. Other abbreviations: CAS, Chemical Abstract Service; LRL, laboratory reporting level; THM, trihalomethane; D, detected in groundwater samples (table 5); na, not available; $\mu \mathrm{g} / \mathrm{L}$, microgram per liter; - not detected]

\begin{tabular}{|c|c|c|c|c|c|c|c|}
\hline Constituent & $\begin{array}{c}\text { Primary use } \\
\text { or source }\end{array}$ & $\begin{array}{c}\text { USGS } \\
\text { parameter } \\
\text { code }\end{array}$ & $\begin{array}{c}\text { CAS } \\
\text { number }{ }^{1}\end{array}$ & $\begin{array}{c}\text { LRL } \\
(\mu g / L)\end{array}$ & $\begin{array}{c}\text { Threshold } \\
\text { type }^{2}\end{array}$ & $\begin{array}{c}\text { Threshold } \\
\text { value } \\
\text { ( } \mu \mathrm{g} / \mathrm{L})\end{array}$ & Detection \\
\hline 1,2,3-Trimethylbenzene & Gasoline hydrocarbon & 77221 & $526-73-8$ & 0.08 & na & na & - \\
\hline 1,3,5-Trimethylbenzene & Organic synthesis & 77226 & $108-67-8$ & 0.04 & NL-CA & 330 & - \\
\hline Vinyl bromide (Bromoethene) & Fire retardant & 50002 & $593-60-2$ & 0.12 & na & na & - \\
\hline Vinyl chloride (Chloroethene) & Organic synthesis & 39175 & $75-01-4$ & 0.08 & MCL-CA & 0.5 & - \\
\hline$o$-Xylene & Gasoline hydrocarbon & 77135 & $95-47-6$ & 0.04 & MCL-CA & ${ }^{6} 1,750$ & - \\
\hline
\end{tabular}

${ }^{1}$ This report contains CAS Registry Numbers ${ }^{\circledR}$, which is a Registered Trademark of the American Chemical Society. CAS recommends the verification of the CASRNs through CAS Client Services ${ }^{\mathrm{SM}}$.

${ }^{2}$ Maximum contaminant level thresholds are listed as MCL-US when the MCL-US and MCL-CA are identical, and as MCL-CA when the MCL-CA is lower than the MCL-US or no MCL-US exists.

${ }^{3}$ The MCL-US threshold for trihalomethanes is the sum of chloroform, bromoform, bromodichloromethane, and dibromochloromethane.

${ }^{4}$ The RSD5 threshold for 1,3-dichloropropene is the sum of its isomers (cis and trans).

${ }^{5}$ In earlier reports in this series, the NL-CA $(0.005 \mu \mathrm{g} / \mathrm{L})$ was used as the comparison threshold for 1,2,3-TCP.

${ }^{6}$ The MCL-CA threshold for $m$ - and $p$-xylene and $o$-xylene is the sum of all three xylene compounds. 
Table 3B. Gasoline oxygenates and degradates, primary uses or sources, comparative thresholds, and reporting information for the U.S. Geological Survey (USGS) National Water Quality Laboratory Schedule 4024.

[The five-digit USGS parameter code is used to uniquely identify a specific constituent or property. Threshold types and threshold levels as of December 20, 2007. Threshold type: MCL-US, U.S. Environmental Protection Agency maximum contaminant level; NL-CA, California Department of Public Health notification level. Other abbreviations: CAS, Chemical Abstract Service; LRL, laboratory reporting level; D, detected in groundwater samples (table 5); na, not available; $\mu \mathrm{g} / \mathrm{L}$, microgram per liter; —, not detected]

\begin{tabular}{|c|c|c|c|c|c|c|c|}
\hline Constituent ${ }^{1}$ & $\begin{array}{c}\text { Primary use } \\
\text { or source }\end{array}$ & $\begin{array}{c}\text { USGS } \\
\text { parameter } \\
\text { code }\end{array}$ & $\begin{array}{c}\text { CAS } \\
\text { number }\end{array}$ & $\begin{array}{c}\text { LRL } \\
(\mu \mathrm{g} / \mathrm{L})\end{array}$ & $\begin{array}{l}\text { Threshold } \\
\text { type }^{2}\end{array}$ & $\begin{array}{c}\text { Threshold } \\
\text { value } \\
\text { ( } \mu \mathrm{g} / \mathrm{L} \text { ) }\end{array}$ & Detection \\
\hline Acetone & Degradate & 81552 & $67-64-1$ & 1.8 & na & na & - \\
\hline tert-Amyl methyl ether (TAME) & Oxygenate & 50005 & $994-05-8$ & 0.05 & na & na & - \\
\hline tert-Butyl alcohol (TBA) & Degradate & 77035 & $75-65-0$ & 1 & NL-CA & 12 & - \\
\hline Methyl acetate & Degradate & 77032 & $79-20-9$ & 0.4 & na & na & - \\
\hline Methyl tert-butyl ether (MTBE) & Oxygenate & 78032 & $1634-04-4$ & 0.04 & MCL-US & 13 & -3 \\
\hline
\end{tabular}

${ }^{1}$ Schedule 4024 was sampled for at two wells.

${ }^{2}$ Maximum contaminant level thresholds are listed as MCL-US when the MCL-US and MCL-CA are identical, and as MCL-CA when the MCL-CA is lower than the MCL-US or no MCL-US exists.

${ }^{3}$ This constituent was detected on the preferred analytical Schedule 2020, not Schedule 4024. 
Table 3C. Pesticides and pesticide degradates, primary uses or sources, comparative thresholds, and reporting information for the U.S. Geological Survey (USGS) National Water Quality Laboratory Schedule 2003.

[The five-digit USGS parameter code is used to uniquely identify a specific constituent or property. Threshold types and threshold levels as of December 20, 2007. Threshold type: HAL-US, U.S. Environmental Protection Agency lifetime health advisory level; MCL-CA, California Department of Public Health maximum contaminant level; MCL-US, U.S. Environmental Protection Agency maximum contaminant level; RSD5-US, U.S. Environmental Protection Agency risk specific dose at a risk factor of $10^{-5}$. Other abbreviations: CAS, Chemical Abstract Service; LRL, laboratory reporting level; D, detected in groundwater samples (table 6); na, not available; $\mu \mathrm{g} / \mathrm{L}$, microgram per liter; - , not detected]

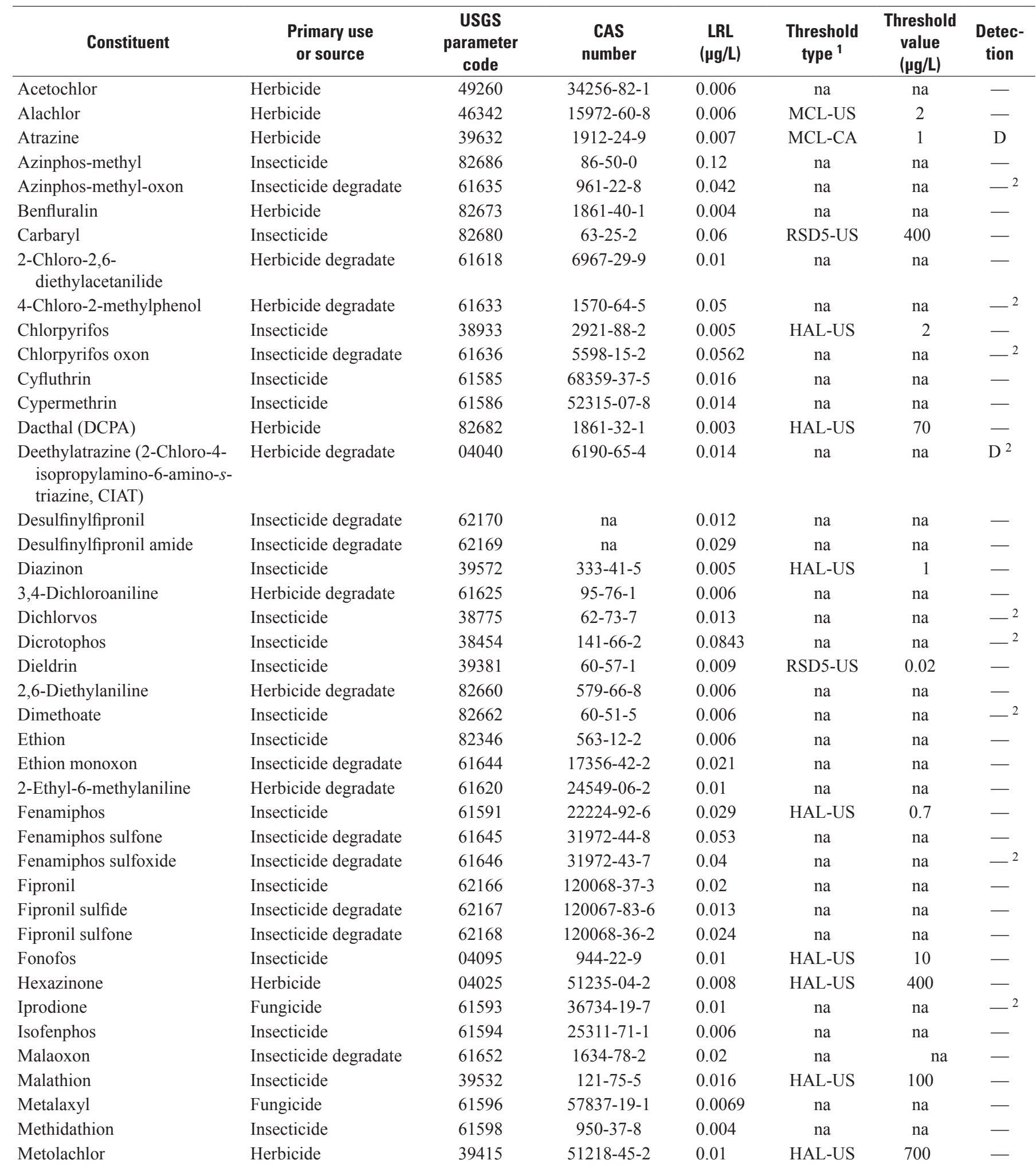


Table 3C. Pesticides and pesticide degradates, primary uses or sources, comparative thresholds, and reporting information for the U.S. Geological Survey (USGS) National Water Quality Laboratory Schedule 2003. —Continued

[The five-digit USGS parameter code is used to uniquely identify a specific constituent or property. Threshold types and threshold levels as of December 20, 2007. Threshold type: HAL-US, U.S. Environmental Protection Agency lifetime health advisory level; MCL-CA, California Department of Public Health maximum contaminant level; MCL-US, U.S. Environmental Protection Agency maximum contaminant level; RSD5-US, U.S. Environmental Protection Agency risk specific dose at a risk factor of $10^{-5}$. Other abbreviations: CAS, Chemical Abstract Service; LRL, laboratory reporting level; D, detected in groundwater samples (table 6); na, not available; $\mu \mathrm{g} / \mathrm{L}$, microgram per liter; - , not detected]

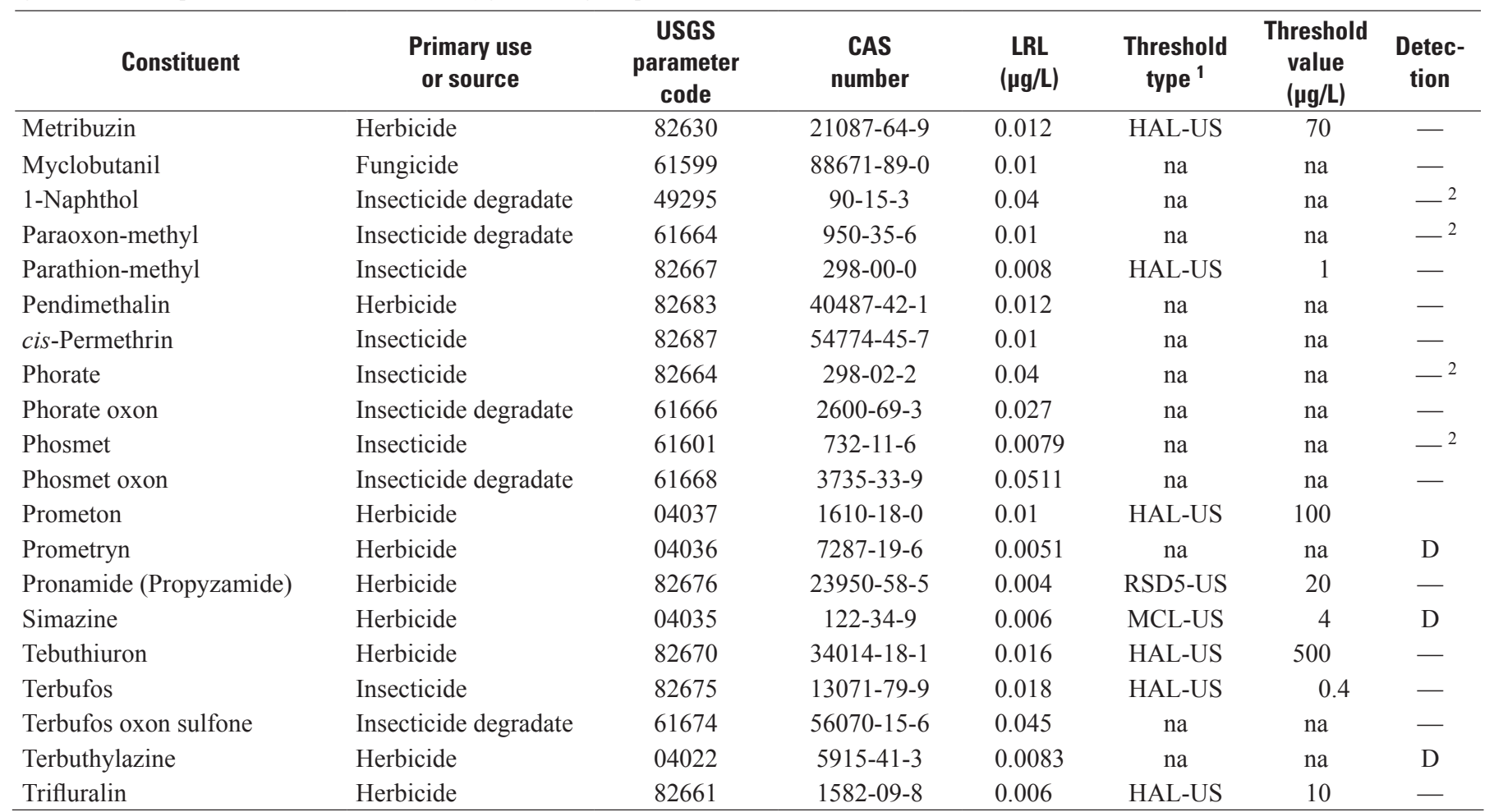

${ }^{1}$ Maximum contaminant level thresholds are listed as MCL-US when the MCL-US and MCL-CA are identical, and as MCL-CA when the MCL-CA is lower than the MCL-US or no MCL-US exists.

${ }^{2}$ The median matrix-spike recovery was less than 70 percent. Low recoveries may indicate that the compound might not have been detected in some samples if it was present at very low concentrations. 
Table 3D. Pharmaceutical compounds, primary uses or sources, comparative thresholds, and reporting information for the U.S. Geological Survey (USGS) National Water Quality Laboratory Schedule 9003.

[The five-digit USGS parameter code is used to uniquely identify a specific constituent or property. Thresholds type and threshold levels as of December 20, 2007. The results for pharmaceutical compounds are not presented in this report; they will be included in subsequent publications. Abbreviations: CAS, Chemical Abstract Service; MDL, method detection limit; na, not available; $\mu \mathrm{g} / \mathrm{L}$, microgram per liter]

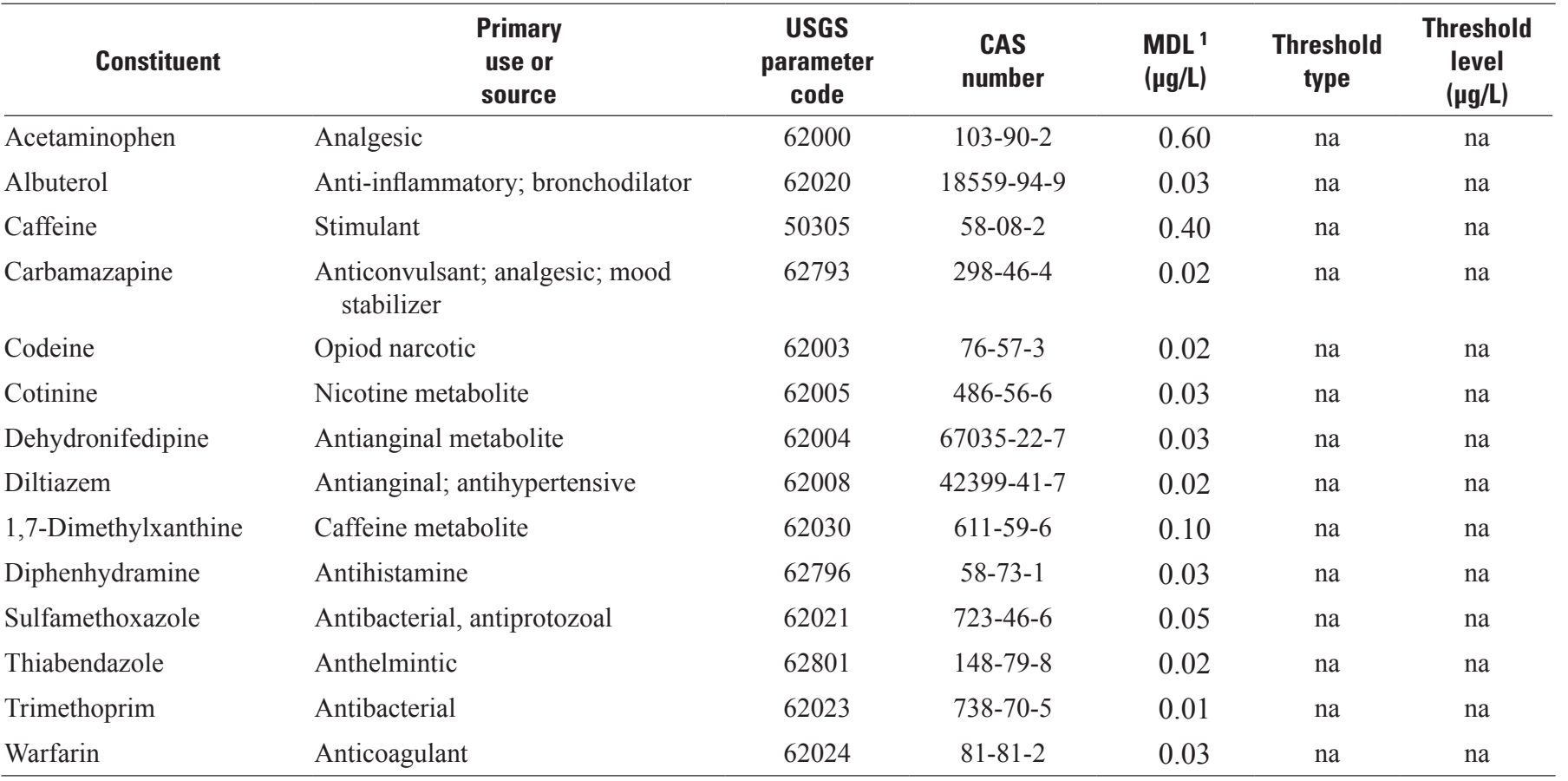

${ }^{1}$ The California Groundwater Ambient Monitoring and Assessment (GAMA) program uses more conservative reporting limits for the pharmaceutical compounds than those recommended by the USGS National Water Quality Laboratory. For albuterol, carbamazepine, codeine, dehydronifedipine, diltiazem, sulfamethoxazole, thiabendazole, trimethoprim, and warfarin, the MDL corresponds to the long-term method reporting limit determined by the USGS Branch of Quality Systems in October 2007 (BQS LT-MDL). For acetaminophen, caffeine, cotinine, diphenhydramine, and 1,7-dimethaxanthine, the MDL corresponds to the effective method detection limit determined from assessing quality-control data associated with GAMA samples collected May 2004 through September 2007 (GAMA E-MDL). The GAMA E-MDLs are higher than the BQS LT-MDLs for those compounds. Detections of constituents reported by the USGS National Water Quality Laboratory with concentrations lower than the BQS LT-MDL or the GAMA E-MDL are reported as nondetections by the GAMA program. 
Table 3E. Constituents of special interest, primary uses or sources, comparative thresholds, and reporting information for Weck Laboratories, Inc.

[The five-digit U.S. Geological Survey (USGS) parameter code is used to uniquely identify a specific constituent or property. Threshold types and threshold levels as of December 20, 2007. Threshold type: HAL-US, U.S. Environmental Protection Agency lifetime health advisory level; MCL-CA, California Department of Public Health maximum contaminant level; NL-CA, California Department of Public Health notification level. Other abbreviations: CAS, Chemical Abstract Service; MRL, minimum reporting level; D, detected in ground-water samples (table 7); $\mu \mathrm{g} / \mathrm{L}$, microgram per liter; —, not detected]

\begin{tabular}{|c|c|c|c|c|c|c|c|}
\hline Constituent & $\begin{array}{c}\text { Primary use } \\
\text { or source }\end{array}$ & $\begin{array}{c}\text { USGS } \\
\text { parameter } \\
\text { code }\end{array}$ & $\begin{array}{c}\text { CAS } \\
\text { number }\end{array}$ & $\begin{array}{c}\text { MRL } \\
(\mu \mathrm{g} / \mathrm{L})\end{array}$ & $\begin{array}{l}\text { Threshold } \\
\text { type }{ }^{1}\end{array}$ & $\begin{array}{c}\text { Threshold } \\
\text { level } \\
(\mu \mathrm{g} / \mathrm{L})\end{array}$ & Detection \\
\hline Perchlorate & Rocket fuel, fireworks, flares & 63709 & $14797-73-0$ & 0.5 & MCL-CA & 6 & $\mathrm{D}$ \\
\hline 1,2,3-Trichloropropane (TCP) & Fumigant, solvent & 77443 & $96-18-4$ & 0.12 & HAL-CA & 40 & $\mathrm{D}^{2}$ \\
\hline 1,4-Dioxane & Industrial solvent & 81582 & $123-91-1$ & 2 & NL-CA & 3 & - \\
\hline
\end{tabular}

${ }^{1}$ Maximum contaminant level thresholds are listed as MCL-US when the MCL-US and MCL-CA are identical, and as MCL-CA when the MCL-CA is lower than the MCL-US or no MCL-US exists.

${ }^{2}$ The median matrix-spike recovery was less than 70 percent. Low recoveries may indicate that the compound might not have been detected in some samples if it was present at very low concentrations.

Table 3F. Nutrients, comparative thresholds, and reporting information for the U.S. Geological Survey (USGS) National Water Quality Laboratory Schedule 2755.

[The five-digit USGS parameter code is used to uniquely identify a specific constituent or property. Threshold types and threshold levels as of December 20, 2007. Threshold type: HAL-US, U.S. Environmental Protection Agency lifetime health advisory level; MCL-US, U.S. Environmental Protection Agency maximum contaminant level. Other abbreviations: CAS, Chemical Abstract Service; LRL, laboratory reporting level; D, detected in groundwater samples (table 8); na, not available; $\mathrm{mg} / \mathrm{L}$, milligram per liter]

\begin{tabular}{|c|c|c|c|c|c|c|}
\hline Constituent & $\begin{array}{c}\text { USGS } \\
\text { parameter } \\
\text { code }\end{array}$ & $\begin{array}{c}\text { CAS } \\
\text { number }\end{array}$ & $\begin{array}{c}\text { LRL } \\
(\mathrm{mg} / \mathrm{L})\end{array}$ & $\begin{array}{l}\text { Threshold } \\
\text { type }^{1}\end{array}$ & $\begin{array}{c}\text { Threshold } \\
\text { level } \\
\text { (mg/L) }\end{array}$ & Detection \\
\hline Ammonia (as nitrogen) & 00608 & $7664-41-7$ & 0.02 & HAL-US & 224.7 & $\mathrm{D}$ \\
\hline Nitrite (as nitrogen) & 00613 & $14797-65-0$ & 0.002 & MCL-US & 1 & $\mathrm{D}$ \\
\hline Nitrite plus nitrate (as nitrogen) & 00631 & na & 0.04 & MCL-US & 10 & $\mathrm{D}$ \\
\hline $\begin{array}{l}\text { Nitrogen, total (ammonia, nitrite, nitrate, } \\
\text { organic nitrogen) }\end{array}$ & 62854 & $17778-88-0$ & 0.06 & na & na & $\mathrm{D}$ \\
\hline Orthophosphate (as phosphorus) & 00671 & $14265-44-2$ & 0.006 & na & na & $\mathrm{D}$ \\
\hline
\end{tabular}

\footnotetext{
${ }^{1}$ Maximum contaminant level thresholds are listed as MCL-US when the MCL-US and MCL-CA are identical, and as MCL-CA when the MCL-CA is lower than the MCL-US or no MCL-US exists.

${ }^{2}$ The HAL-US is $30 \mathrm{mg} / \mathrm{L}$ "as ammonia." To facilitate comparison to the analytical results, we have converted and reported this HAL-US as $24.7 \mathrm{mg} / \mathrm{L}$ "as nitrogen."
} 
Table 3G. Major and minor ions and trace elements, comparative thresholds, and reporting information for the U.S. Geological Survey (USGS) National Water Quality Laboratory Schedule 1948.

[The five-digit USGS parameter code is used to uniquely identify a specific constituent or property. Threshold types and threshold levels as of December 20, 2007. Threshold type: HAL-US, U.S. Environmental Protection Agency lifetime health advisory level; MCL-CA, California Department of Public Health maximum contaminant level; MCL-US, U.S. Environmental Protection Agency maximum contaminant level; NL-CA, California Department of Public Health notification level; SMCL-CA, California Department of Public Health secondary maximum contaminant level. Other abbreviations: CAS, Chemical Abstract Service; LRL, laboratory reporting level; D, detected in groundwater samples (tables 9, 10); na, not available; mg/L, milligram per liter; $\mu \mathrm{g} / \mathrm{L}$, microgram per liter]

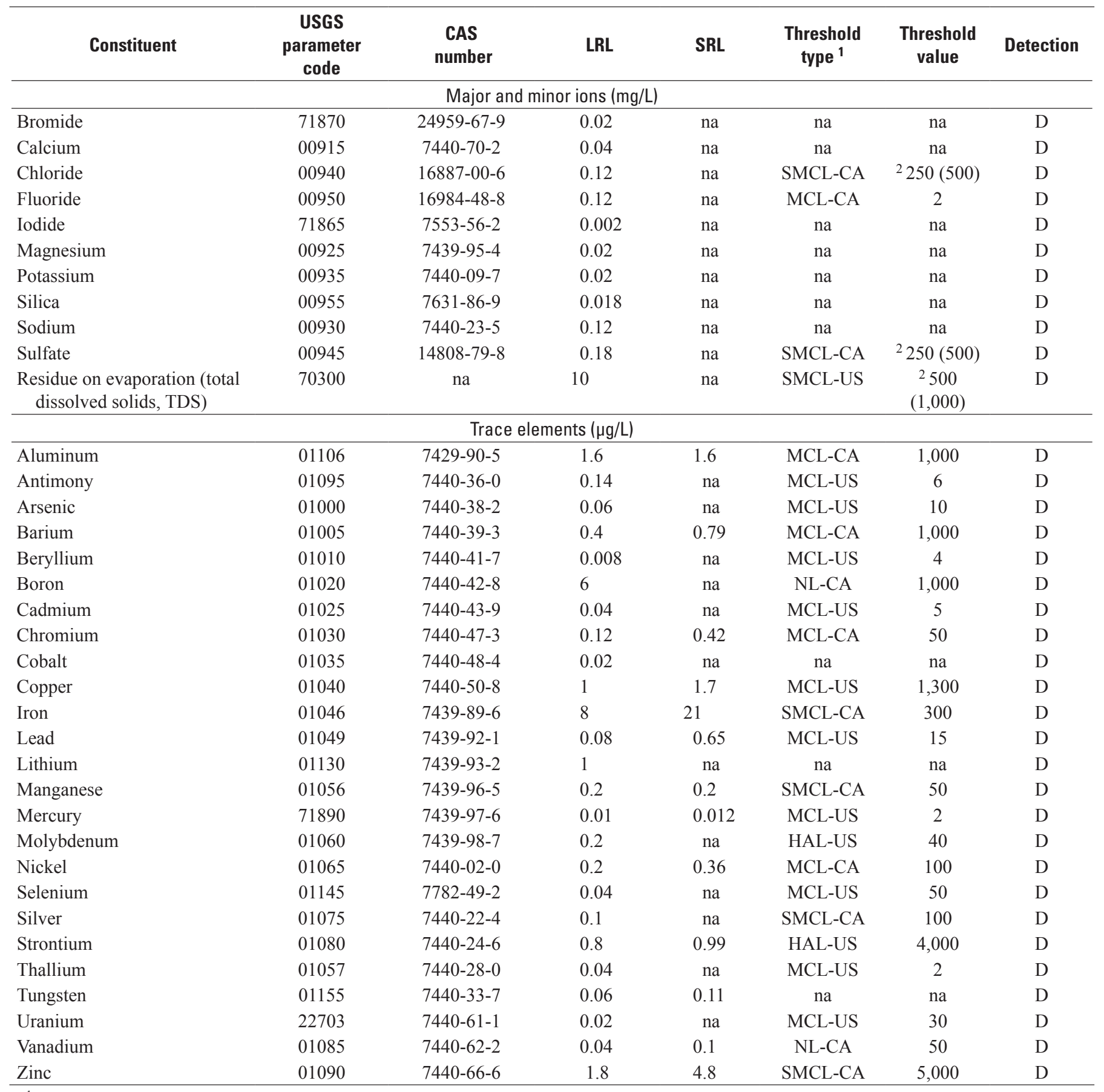

${ }^{1}$ Maximum contaminant level thresholds are listed as MCL-US when the MCL-US and MCL-CA are identical, and as MCL-CA when the MCL-CA is lower than the MCL-US or no MCL-US exists.

${ }^{2}$ The recommended SMCL-CA thresholds for chloride, sulfate, and TDS are listed with the upper SMCL-CA thresholds in parentheses. 
Table 3H. Arsenic, chromium, and iron species, comparative thresholds, and reporting information for the U.S. Geological Survey (USGS) Trace Metal Laboratory, Boulder, Colorado.

[The five-digit USGS parameter code is used to uniquely identify a specific constituent or property. Threshold types and threshold levels as of December 20, 2007. Threshold type: MCL-CA, California Department of Public Health maximum contaminant level; MCL-US, U.S. Environmental Protection Agency maximum contaminant level; SMCL-US, U.S. Environmental Protection Agency secondary maximum contaminant level. Other abbreviations: CAS, Chemical Abstract Service; MDL, method detection limit; na, not available; $\mu \mathrm{g} / \mathrm{L}$, microgram per liter; D, detected in groundwater samples (table 11)]

\begin{tabular}{|c|c|c|c|c|c|c|}
\hline $\begin{array}{c}\text { Constituent } \\
\text { (valence state) }\end{array}$ & $\begin{array}{c}\text { USGS } \\
\text { parameter } \\
\text { code }\end{array}$ & $\begin{array}{c}\text { CAS } \\
\text { number }\end{array}$ & $\begin{array}{l}\text { MDL } \\
(\mu \mathrm{g} / \mathrm{L})\end{array}$ & $\begin{array}{l}\text { Threshold } \\
\text { type }^{1}\end{array}$ & $\begin{array}{c}\text { Threshold } \\
\text { level } \\
\text { ( } \mu \mathrm{g} / \mathrm{L})\end{array}$ & Detection \\
\hline Arsenic(III) & 99034 & $22569-72-8$ & 1 & na & na & $\mathrm{D}$ \\
\hline Arsenic(total) & 99033 & $7440-38-2$ & 0.5 & MCL-US & 10 & $\mathrm{D}$ \\
\hline Chromium(VI) & 01032 & $18540-29-9$ & 1 & na & na & $\mathrm{D}$ \\
\hline Iron(total) & 01046 & $7439-89-6$ & 2 & SMCL-US & 300 & $\mathrm{D}$ \\
\hline
\end{tabular}

\footnotetext{
${ }^{1}$ Maximum contaminant level thresholds are listed as MCL-US when the MCL-US and MCL-CA are identical, and as MCL-CA when the MCL-CA is lower than the MCL-US or no MCL-US exists.
} 
Table 3I. Isotopic and radioactive constituents, comparative thresholds, and reporting information for laboratories.

[The five-digit U.S. Geological Survey (USGS) parameter code is used to uniquely identify a specific constituent or property. Threshold types and threshold levels as of December 20, 2007. Stable isotope ratios are reported in the standard delta notation $(\delta)$, the ratio of the abundance of a heavier isotope to the more common lighter isotope of that element, relative to a standard reference material. Threshold type: MCL-CA, California Department of Public Health maximum contaminant level; MCL-US, U.S. Environmental Protection Agency maximum contaminant level. Other abbreviations: C, carbon; H, hydrogen:, O, oxygen; CAS, Chemical Abstract Service; CSU, 1-sigma combined standard uncertainty; 2CSU, 2-sigma combined standard uncertainty; MRL, minimum reporting level; MU, method uncertainty; na, not available; $\mathrm{pCi} / \mathrm{L}$, picocurie per liter; Prop., proposed; $\mathbf{s s L}_{\mathrm{C}}$, sample-specific critical level; SSMDC, sample specific minimum detectable concentration; D, detected in groundwater samples ( $\underline{\text { tables } 12}$ and $\underline{13 \mathrm{~A}, \mathrm{~B}, \mathrm{C})}$ ]

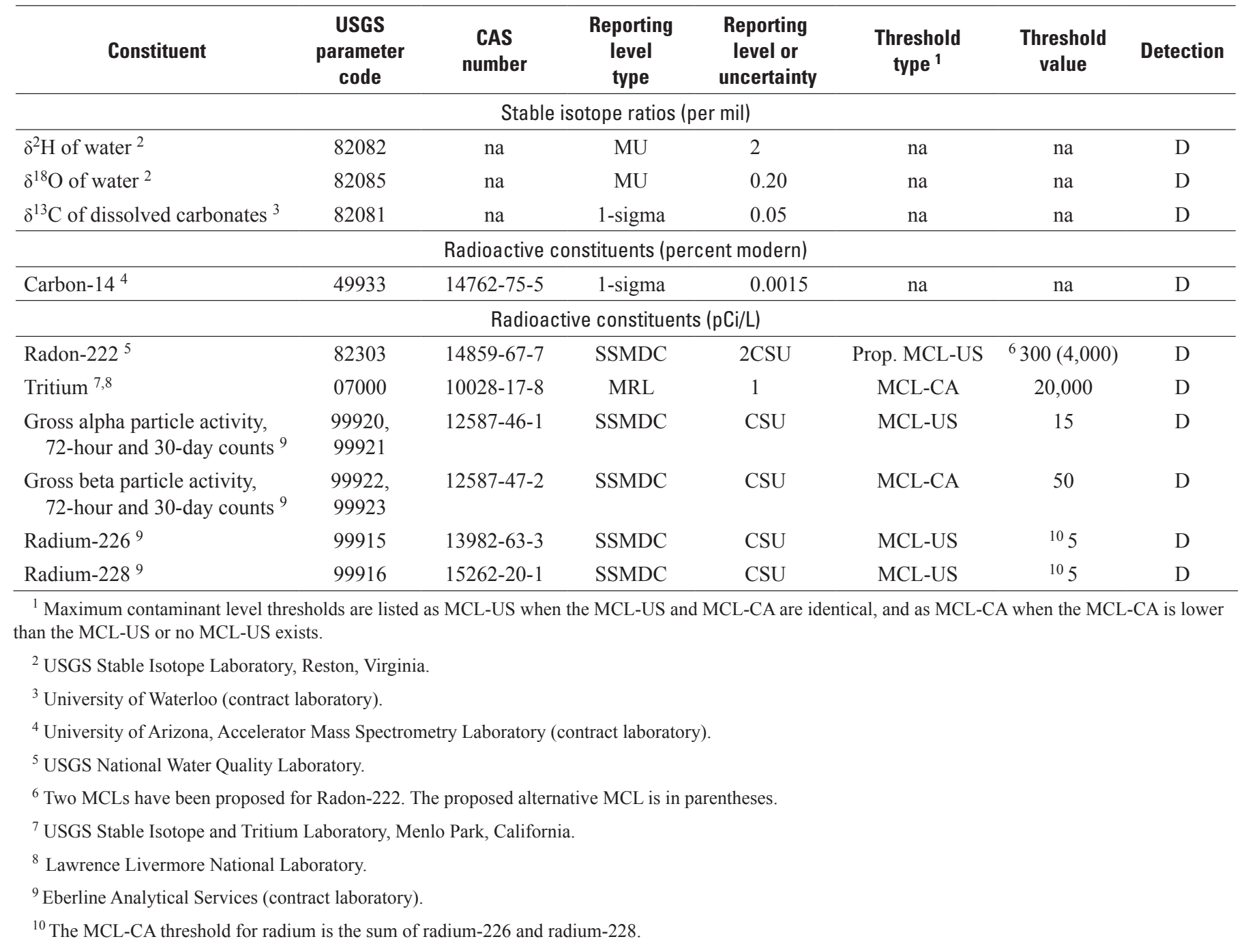


Table 3J. Noble gases and tritium, comparison thresholds and reporting information for the Lawrence Livermore National Laboratory.

[The five-digit U.S. Geological survey (USGS) parameter code is used to uniquely identify a specific constituent or property. Threshold types and threshold levels as of December 20, 2007. Threshold type: MCL-CA, California Department of Public Health maximum contaminant level. Other abbreviations: CAS, Chemical Abstract Service; MU, method uncertainty; na, not available; $\mathrm{cm}^{3} \mathrm{STP} / \mathrm{g}$, cubic centimeter of gas at standard temperature and pressure per gram of water; $\mathrm{pCi} / \mathrm{L}$, picocurie per liter]

\begin{tabular}{|c|c|c|c|c|c|c|}
\hline Constituent & $\begin{array}{c}\text { USGS } \\
\text { parameter } \\
\text { code }\end{array}$ & $\begin{array}{c}\text { CAS } \\
\text { number }\end{array}$ & $\begin{array}{c}\text { MU } \\
\text { (percent) }\end{array}$ & $\begin{array}{l}\text { Reporting } \\
\text { units }\end{array}$ & $\begin{array}{c}\text { Threshold } \\
\text { type }^{1}\end{array}$ & $\begin{array}{c}\text { Threshold } \\
\text { value } \\
\text { (pCi/L) }\end{array}$ \\
\hline Helium-3/Helium-4 & 61040 & $\mathrm{na} / 7440-59-7$ & 0.75 & atom ratio & na & na \\
\hline Argon & 85563 & $7440-37-1$ & 2 & $\mathrm{~cm}^{3} \mathrm{STP} / \mathrm{g}$ & na & na \\
\hline Helium-4 & 85561 & $7440-59-7$ & 2 & $\mathrm{~cm}^{3} \mathrm{STP} / \mathrm{g}$ & na & na \\
\hline Krypton & 85565 & 7439-90-9 & 2 & $\mathrm{~cm}^{3} \mathrm{STP} / \mathrm{g}$ & na & na \\
\hline Xenon & 85567 & $7440-63-3$ & 2 & $\mathrm{~cm}^{3} \mathrm{STP} / \mathrm{g}$ & na & na \\
\hline Tritium & 07000 & $10028-17-8$ & 1 & $\mathrm{pCi} / \mathrm{L}$ & MCL-CA & 20,000 \\
\hline
\end{tabular}

\footnotetext{
${ }^{1}$ Maximum contaminant level thresholds are listed as MCL-US when the MCL-US and MCL-CA are identical, and as MCL-CA when the MCL-CA is lower than the MCL-US or no MCL-US exists.
} 
Table 4. Water-quality indicators in samples collected for the Colorado River Groundwater Ambient Monitoring and Assessment (GAMA) study, California, autumn 2007.

[The five digit number below the constituent name is the U.S. Geological Survey parameter code used to uniquely identify a specific constituent or property. Samples from all 28 wells were analyzed, but only samples with detections are listed. GAMA well identification number: COLOR, Colorado River study unit grid well; COLORU, Colorado River study unit understanding well. Threshold types and threshold levels as of December 20, 2007. Threshold type: SMCL-US, U.S. Environmental Protection Agency secondary maximum contaminant level; SMCL-CA, California Department of Public Health secondary maximum contaminant level. Other abbreviations: $\mathrm{LRL}$, laboratory reporting level; ${ }^{\circ} \mathrm{C}$, degrees Celsius; $\mathrm{mg} / \mathrm{L}$, milligram per liter; $\mu \mathrm{S} / \mathrm{cm}$, microsiemens per centimeter; $\mathrm{CaCO}_{3}$, calcium carbonate; *, value above threshold value or outside threshold range; **, value above upper threshold value]

\begin{tabular}{|c|c|c|c|c|c|c|c|c|}
\hline $\begin{array}{c}\text { GAMA well } \\
\text { identification } \\
\text { number }\end{array}$ & $\begin{array}{l}\text { Dissolved } \\
\text { oxygen, } \\
\text { field } \\
\text { (mg/L) } \\
(00300)\end{array}$ & $\begin{array}{c}\text { Water } \\
\text { temperature, } \\
\text { field } \\
\left({ }^{\circ} \mathrm{C}\right) \\
(00010)\end{array}$ & $\begin{array}{c}\mathrm{pH}, \\
\text { lab } \\
\text { (standard } \\
\text { units) } \\
(00403)\end{array}$ & $\begin{array}{c}\text { pH, } \\
\text { field } \\
\text { (standard } \\
\text { units) } \\
(00400)\end{array}$ & $\begin{array}{c}\text { Specific } \\
\text { conductance, } \\
\text { lab } \\
(\mu \mathrm{S} / \mathrm{cm} \\
\left.\text { at } 25^{\circ} \mathrm{C}\right) \\
(90095)\end{array}$ & $\begin{array}{c}\text { Specific } \\
\text { conductance, } \\
\text { field } \\
(\mu \mathrm{S} / \mathrm{cm} \\
\left.\text { at } 25^{\circ} \mathrm{C}\right) \\
(00095)\end{array}$ & $\begin{array}{c}\text { Alkalinity, } \\
\text { lab } \\
\text { (mg/L as } \\
\left.\mathrm{CaCO}_{3}\right) \\
(29801)\end{array}$ & $\begin{array}{c}\text { Alkalinity, } \\
\text { field } \\
\text { (mg/L as } \\
\left.\mathrm{CaCO}_{3}\right) \\
(29802)\end{array}$ \\
\hline $\begin{array}{l}\text { Threshold } \\
\text { type }\end{array}$ & na & na & SMCL-US & SMCL-US & SMCL-CA & SMCL-CA & na & na \\
\hline [LRL] & {$[0.2]$} & {$[0.0-38.5]$} & {$[0-14]$} & {$[0-14]$} & [5] & [5] & [5] & [1] \\
\hline \multicolumn{9}{|c|}{ Grid wells } \\
\hline$\overline{\text { COLOR-01 }}$ & 6.8 & 17.5 & 7.7 & 7.5 & $* 1,210$ & $* 1,190$ & 150 & 136 \\
\hline COLOR-02 & 4.2 & 25.0 & 7.8 & 7.6 & $* 1,270$ & $* 1,260$ & 152 & 137 \\
\hline COLOR-03 & 0.2 & 24.0 & 7.4 & 7.5 & $* * 2190$ & $* * 2,180$ & 284 & 254 \\
\hline COLOR-04 & 0.1 & 22.0 & 7.8 & 7.7 & $* 1,590$ & $* 1,560$ & 273 & 268 \\
\hline COLOR-09 & 0.2 & 31.5 & 7.8 & 7.8 & $* * 1,830$ & $* * 1,880$ & 192 & 156 \\
\hline COLOR-10 & 0.3 & 25.0 & 7.5 & 7.4 & $* * 2,320$ & $* * 2,360$ & 303 & 250 \\
\hline COLOR-11 & 0.6 & 28.5 & 7.2 & 7.0 & $* * 3,930$ & $* * 4,000$ & 314 & 254 \\
\hline COLOR-12 & 1.6 & 33.5 & 8.0 & 7.9 & 796 & 804 & 109 & 86 \\
\hline COLOR-13 & 4.7 & 29.0 & 7.7 & 7.6 & *959 & $* 963$ & 153 & 147 \\
\hline COLOR-14 & 0.2 & 27.0 & 7.7 & 7.6 & *911 & *926 & 159 & 154 \\
\hline COLOR-15 & $<0.2$ & 23.0 & 7.3 & 7.2 & $* * 2,640$ & $* * 2,660$ & 321 & 315 \\
\hline COLOR-16 & 0.3 & 20.5 & 7.7 & 7.6 & $* * 2,070$ & $* * 2,080$ & 318 & 315 \\
\hline COLOR-17 & 3.8 & 27.0 & 7.8 & 7.8 & $* 1,320$ & $* 1,340$ & 89 & 85 \\
\hline COLOR-18 & 0.6 & 32.0 & 8.0 & 8.0 & $* * 1,730$ & $* * 1,770$ & 147 & 141 \\
\hline COLOR-19 & 1.8 & 24.0 & 7.6 & 7.5 & $* * 2,910$ & $* * 2,890$ & 296 & 293 \\
\hline COLOR-20 & 7.2 & 35.5 & $* 8.9$ & $* 8.9$ & 665 & 678 & 66 & 62 \\
\hline COLORU-08 & 0.2 & 21.5 & 7.8 & 7.5 & $* * 2,160$ & 2,150 & 286 & 285 \\
\hline
\end{tabular}

\footnotetext{
${ }^{1}$ The SMCL-CA for specific conductance has recommended and upper threshold values. The upper value is shown in parentheses.
} 
Table 5. Volatile organic compounds (VOC) detected in samples collected for the Colorado River Groundwater Ambient Monitoring and Assessment (GAMA) study, California, autumn 2007.

[The five-digit number in parentheses below the constituent name is the U.S. Geological Survey parameter code used to uniquely identify a specific constituent or property. Samples from all 28 wells were analyzed. Analytes are listed in order of decreasing detection frequency in the 20 grid wells. All analytes are listed in tables 3A,B. GAMA well identification number: COLOR, Colorado River study unit grid well; COLORU, Colorado River study unit understanding well. Threshold types and threshold levels as of December 20, 2007. Threshold type: NL-CA, CDPH notification level; MCL-US, U.S. Environmental Protection Agency maximum contaminant level; MCL-CA, California Department of Public Health maximum contaminant level. Other abbreviations: THM, trihalpmethane; E, estimated value; LRL, laboratory reporting level; DBP, disinfection by-product; $\mu \mathrm{g} / \mathrm{L}$, microgram per liter; —, not detected]

\begin{tabular}{|c|c|c|c|c|c|}
\hline \multirow[b]{2}{*}{$\begin{array}{c}\text { GAMA well } \\
\text { identification number }\end{array}$} & $\begin{array}{c}\text { Gasoline } \\
\text { hydrocarbon }\end{array}$ & Fumigant & $\begin{array}{l}\text { Disinfection by- } \\
\text { product (THM) }\end{array}$ & Gasoline oxygenate & \multirow[b]{2}{*}{$\begin{array}{c}\text { VOC } \\
\text { detections } \\
\text { per well }\end{array}$} \\
\hline & $\begin{array}{l}\text { 1,2,4-Trimethyl- } \\
\text { benzene } \\
(\mu \mathrm{g} / \mathrm{L}) \\
(77222)\end{array}$ & $\begin{array}{c}\text { 1,2-Dichloro- } \\
\text { propane } \\
(\mu \mathrm{g} / \mathrm{L}) \\
(34541)\end{array}$ & $\begin{array}{l}\text { Chloroform, } \\
\text { ( } \mu \mathrm{g} / \mathrm{L}) \\
(32106)\end{array}$ & $\begin{array}{c}\text { Methyl tert-butyl } \\
\text { ether (MTBE), } \\
(\mu \mathrm{g} / \mathrm{L}) \\
(\mathbf{7 8 0 3 2})\end{array}$ & \\
\hline Threshold type ${ }^{1}$ & 330 & 5 & MCL-US & MCL-CA & \\
\hline \multicolumn{6}{|c|}{ Grid wells } \\
\hline COLOR-03 & E0.03 & - & - & - & 1 \\
\hline COLOR-05 & - & 0.10 & - & - & 1 \\
\hline COLOR-06 & E0.09 & - & - & - & 1 \\
\hline COLOR-07 & E0.06 & 0.91 & - & - & 2 \\
\hline Number of detections & 4 & 3 & 2 & 0 & 9 \\
\hline Detection frequency (percentage) & 20 & 15 & 10 & 0 & ${ }^{2} 35$ \\
\hline \multicolumn{6}{|c|}{ Understanding wells } \\
\hline COLORU-04 & - & - & - & E0.1 & 1 \\
\hline COLORU-05 & - & - & E0.04 & - & 1 \\
\hline COLORU-06 & - & - & E0.02 & - & 1 \\
\hline
\end{tabular}

\footnotetext{
${ }^{1}$ Maximum contaminant level thresholds are listed as MCL-US when the MCL-US and MCL-CA are identical, and as MCL-CA when the MCL-CA is lower than the MCL-US or no MCL-US exists..

${ }^{2}$ Frequency of detection of at least one volatile organic compound (VOC) in the grid wells.
} 
Table 6. Pesticides and pesticide degradates detected in samples collected for the Colorado River Groundwater Ambient Monitoring and Assessment (GAMA) study, California, autumn 2007.

[The five-digit number in parentheses below the constituent name is the U.S. Geological Survey parameter code used to uniquely identify a specific constituent or property. Samples from all 28 wells were analyzed, but only samples with detections are listed. Analytes are listed in order of decreasing detection frequency in the 20 grid wells. All analytes are listed in table 3C. GAMA well identification number: COLOR, Colorado River study unit grid well; COLORU, Colorado River study unit understanding well. Threshold types and threshold levels as of December 20, 2007. Threshold type: MCL-US, U.S. Environmental Protection Agency maximum contaminant level; MCL-CA; California Department of Public Health maximum contaminant level. Other abbreviations: E, estimated value; $\mathrm{LRL}$, laboratory reporting level; $\mu \mathrm{g} / \mathrm{L}$, microgram per liter; —, not detected]

\begin{tabular}{|c|c|c|c|c|c|c|}
\hline $\begin{array}{l}\text { GAMA well } \\
\text { identification } \\
\text { number }\end{array}$ & $\begin{array}{c}\text { Deethylatrazine } \\
(\mu \mathrm{g} / \mathrm{L}) \\
(04040)\end{array}$ & $\begin{array}{c}\text { Simazine } \\
(\mu \mathrm{g} / \mathrm{L}) \\
(04035)\end{array}$ & $\begin{array}{c}\text { Atrazine } \\
(\mu \mathrm{g} / \mathrm{L}) \\
(39632)\end{array}$ & $\begin{array}{c}\text { Prometryn, } \\
\text { ( } \mu \mathrm{g} / \mathrm{L}) \\
(04036)\end{array}$ & $\begin{array}{c}\text { Terbuthylazine, } \\
\text { ( } \mu \mathrm{g} / \mathrm{L}) \\
(04022)\end{array}$ & \multirow{4}{*}{$\begin{array}{c}\text { Pesticide } \\
\text { detections } \\
\text { per well }\end{array}$} \\
\hline Threshold type ${ }^{1}$ & na & MCL-US & MCL-CA & na & na & \\
\hline Threshold level & na & 4 & 1 & na & na & \\
\hline [LRL] & {$[0.014]$} & {$[0.006]$} & {$[0.007]$} & {$[0.0059]$} & {$[0.008]$} & \\
\hline COLOR-02 & E0.005 & - & - & - & - & 1 \\
\hline COLOR-11 & - & E0.007 & - & - & - & 1 \\
\hline COLOR-15 & - & - & - & E0.005 & - & 1 \\
\hline Number of detections & 2 & 1 & 1 & 1 & & 5 \\
\hline
\end{tabular}


Table 7. Constituents of special interest (perchlorate and 1,2,3-trichloropropane [1,2,3-TCP]) detected in samples collected for the Colorado River Groundwater Ambient Monitoring and Assessment (GAMA) study, California, autumn 2007.

[The five-digit number in parentheses below the constituent name is the U.S. Geological Survey parameter code used to uniquely identify a specific constituent or property. Information about the analytes given in table 3E. Samples from all 28 wells were analyzed for perchlorate and 1,2,3-TCP; samples from the Palo Verde study area wells were sampled for 1,4 dioxane, and only wells with at least one detection are listed. GAMA well identification number: COLOR; Colorado River study unit grid well; COLORU; Colorado River study unit understanding well. Threshold types and threshold levels as of December 20, 2007. Threshold type: MCL-CA, California Department of Public Health maximum contaminant level; HAL-US, USEPA lifetime health advisory. Other abbreviations: MRL, minimum reporting level; $\mu \mathrm{g} / \mathrm{L}$, microgram per liter; - , analyzed but not detected]

\begin{tabular}{|c|c|c|}
\hline GAMA well identification number & $\begin{array}{c}\text { Perchlorate } \\
(\mu \mathrm{g} / \mathrm{L}) \\
(63790)\end{array}$ & $\begin{array}{c}\text { 1,2,3-Trichloropropane } \\
(\mu \mathrm{g} / \mathrm{L}) \\
(77443)\end{array}$ \\
\hline Threshold type ${ }^{1}$ & MCL-CA & HAL-US \\
\hline Threshold level & 6 & 40 \\
\hline [MRL] & [0.10] & {$[0.0050]$} \\
\hline \multicolumn{3}{|c|}{ Grid wells } \\
\hline COLOR-01 & 1.5 & - \\
\hline COLOR-02 & 1.8 & - \\
\hline COLOR-08 & 0.20 & - \\
\hline COLOR-10 & - & 0.008 \\
\hline COLOR-11 & 0.42 & - \\
\hline COLOR-12 & 0.69 & - \\
\hline COLOR-13 & 0.82 & - \\
\hline COLOR-17 & 0.87 & - \\
\hline COLOR-18 & 2.4 & - \\
\hline COLOR-20 & 1.2 & - \\
\hline Number of detections & 9 & 1 \\
\hline Detection frequency (percent) & 45 & 5 \\
\hline \multicolumn{3}{|c|}{ Understanding wells } \\
\hline COLORU-05 & 1.0 & - \\
\hline COLORU-06 & 1.6 & - \\
\hline
\end{tabular}

\footnotetext{
${ }^{1}$ Maximum contaminant level thresholds are listed as MCL-US when the MCL-US and MCL-CA are
} identical, and as MCL-CA when the MCL-CA is lower than the MCL-US or no MCL-US exists. 
Table 8. Nutrients detected in samples collected for the Colorado River Groundwater Ambient Monitoring and Assessment (GAMA) study, California, autumn 2007.

[The five-digit number in parentheses below the constituent name is the U.S. Geological Survey parameter code used to uniquely identify a specific constituent or property. Samples from all 28 wells were analyzed, but only samples with detections are listed. Information about the analytes is given in table 3F. GAMA well identification number: COLOR, Colorado River study unit grid well; COLORU, Colorado River study unit understanding well. Threshold type and threshold levels as of December 20, 2007. Threshold type: MCL-CA, California Department of Public Health maximum contaminant level; MCL-US; U.S. Environmental Protection Agency maximum contaminant level; HAL-US, U.S. Environmental Protection Agency lifetime health advisory level. Other abbreviations: E, estimated value; LRL, laboratory reporting level; na, not available; mg/L, milligram per liter; —, not detected]

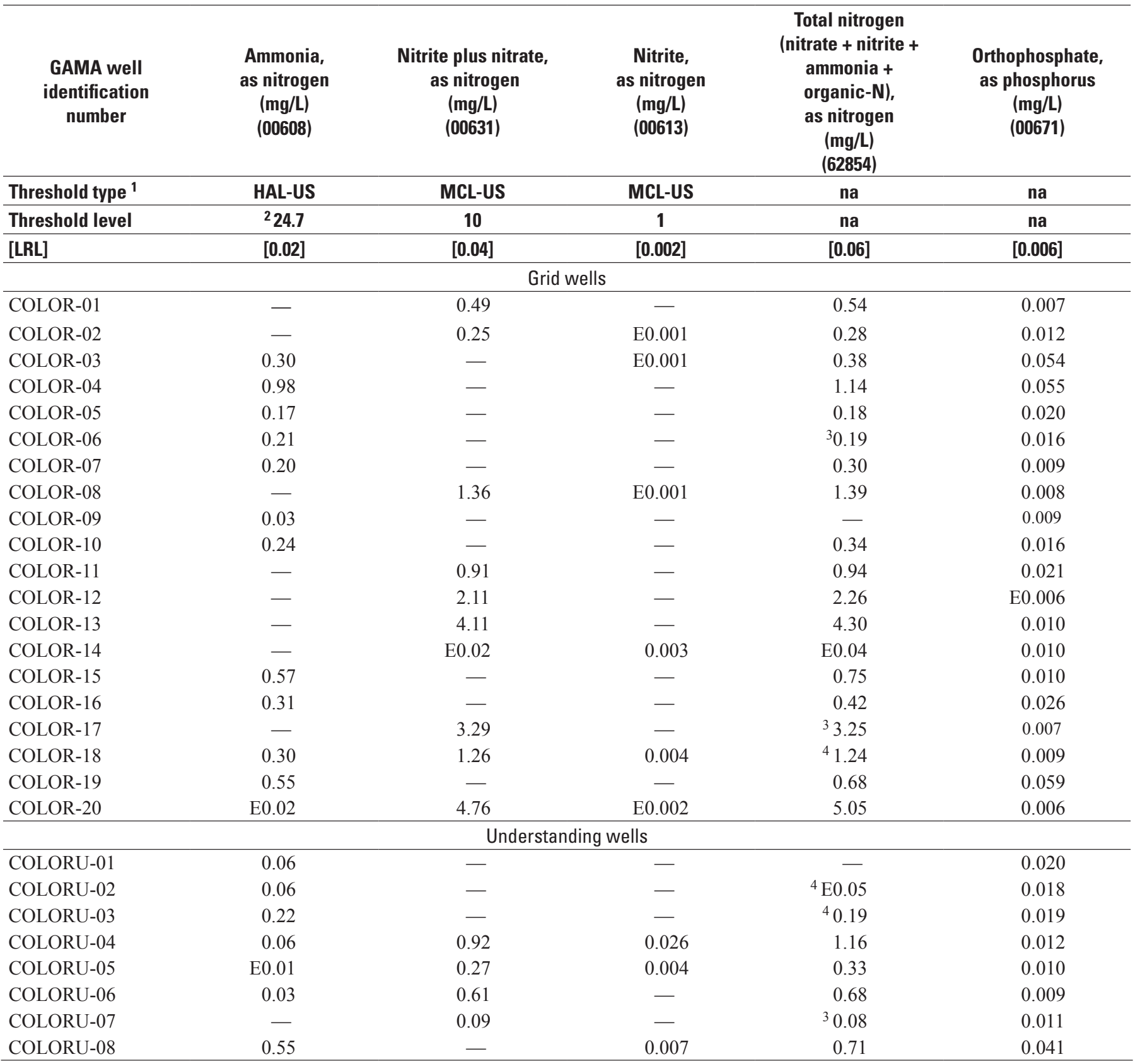

\footnotetext{
${ }^{1}$ Maximum contaminant level thresholds are listed as MCL-US when the MCL-US and MCL-CA are identical, and as MCL-CA when the MCL-CA is lower than the MCL-US or no MCL-US exists.

${ }^{2}$ The HAL-US is $30 \mathrm{mg} / \mathrm{L}$ "as ammonia." To facilitate comparison to the analytical results, we have converted and reported this HAL-US as $24.7 \mathrm{mg} / \mathrm{L}$ "as nitrogen."

${ }^{3}$ Total nitrogen in these samples is less than the sum of the filtered nitrogen analytes and falls outside the U.S. Geological Survey National Water Quality Laboratory acceptance criterion of a 10 percent relative percent difference.

${ }^{4}$ Total nitrogen in these samples is less than the sum of the filtered nitrogen analytes, but falls outside of the U.S. Geological Survey National Water Quality Laboratory acceptance criterion of a 10 percent relative percent difference.
} 


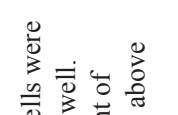

एक्ष

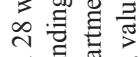

忢芯

苛票矛

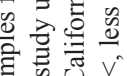

至

㐫这:

잉 웜

현 $\sum_{\text {i }}$

훙ㅎㅇ

包完

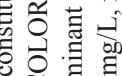

U 坖

चे च

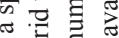

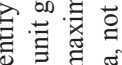

겸

중류

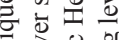

党瓷

용ㅎㅁ

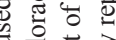

웡 苛

¿

홍 은

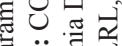

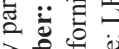

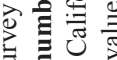

产芯

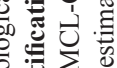

远范

象关

응

我

这

ज्ञ तै

苞

寻穴灾

ठ․ㄹ ङ

Е ह च च

3.

क्ष

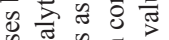

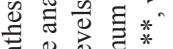

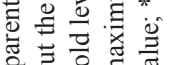

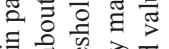

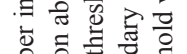

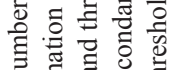

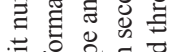

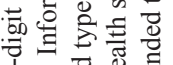

i

过

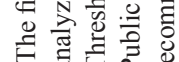

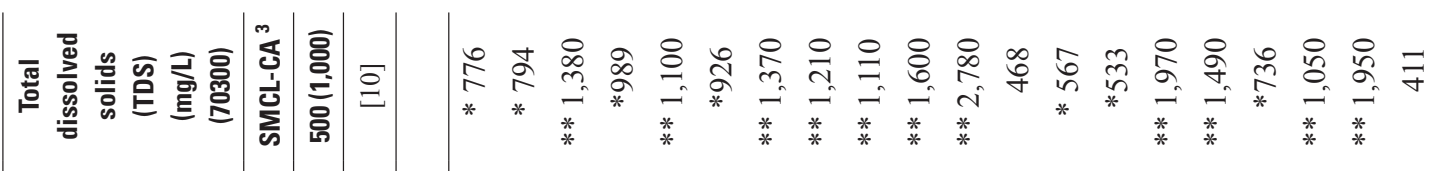

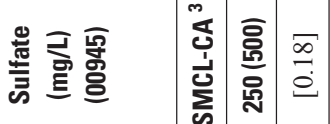

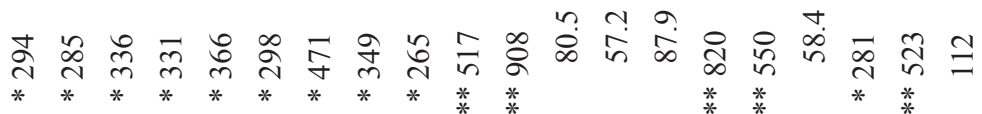

总寅员员

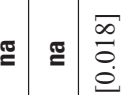

을 흘

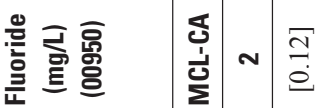

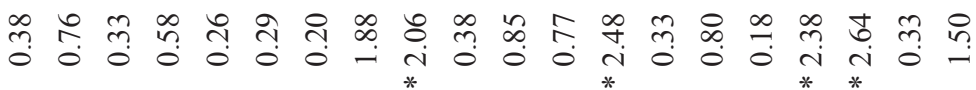

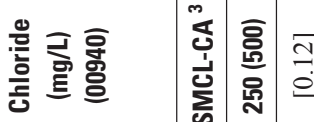

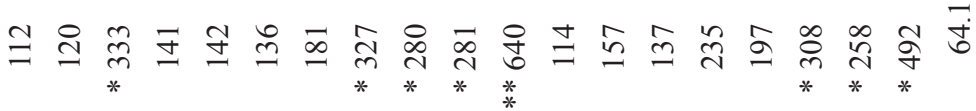

遇

尊

总

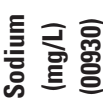

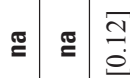

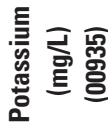

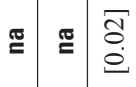

言

$\cong \Xi \Xi$

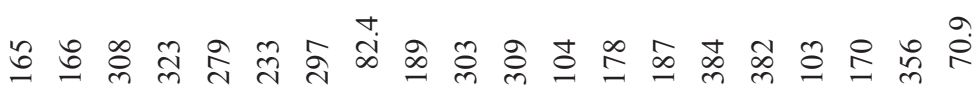

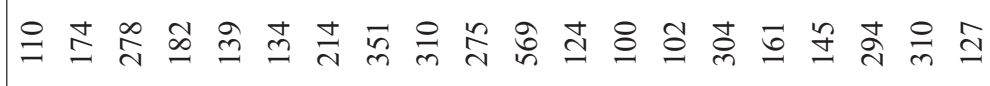

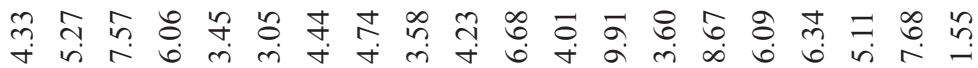

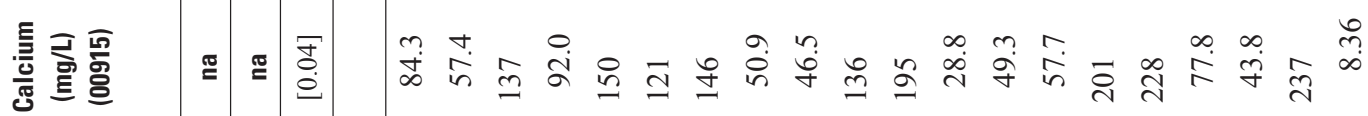

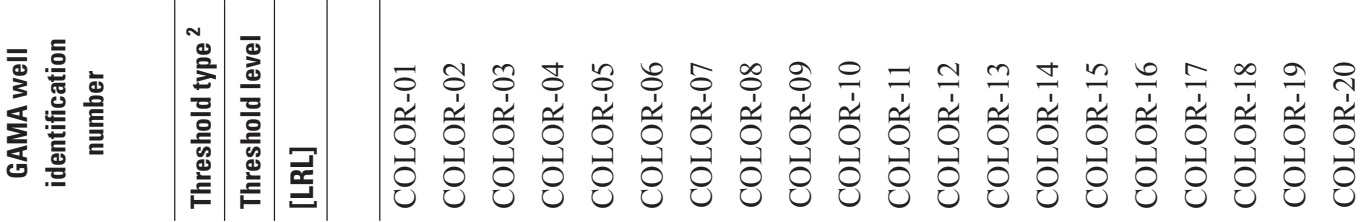




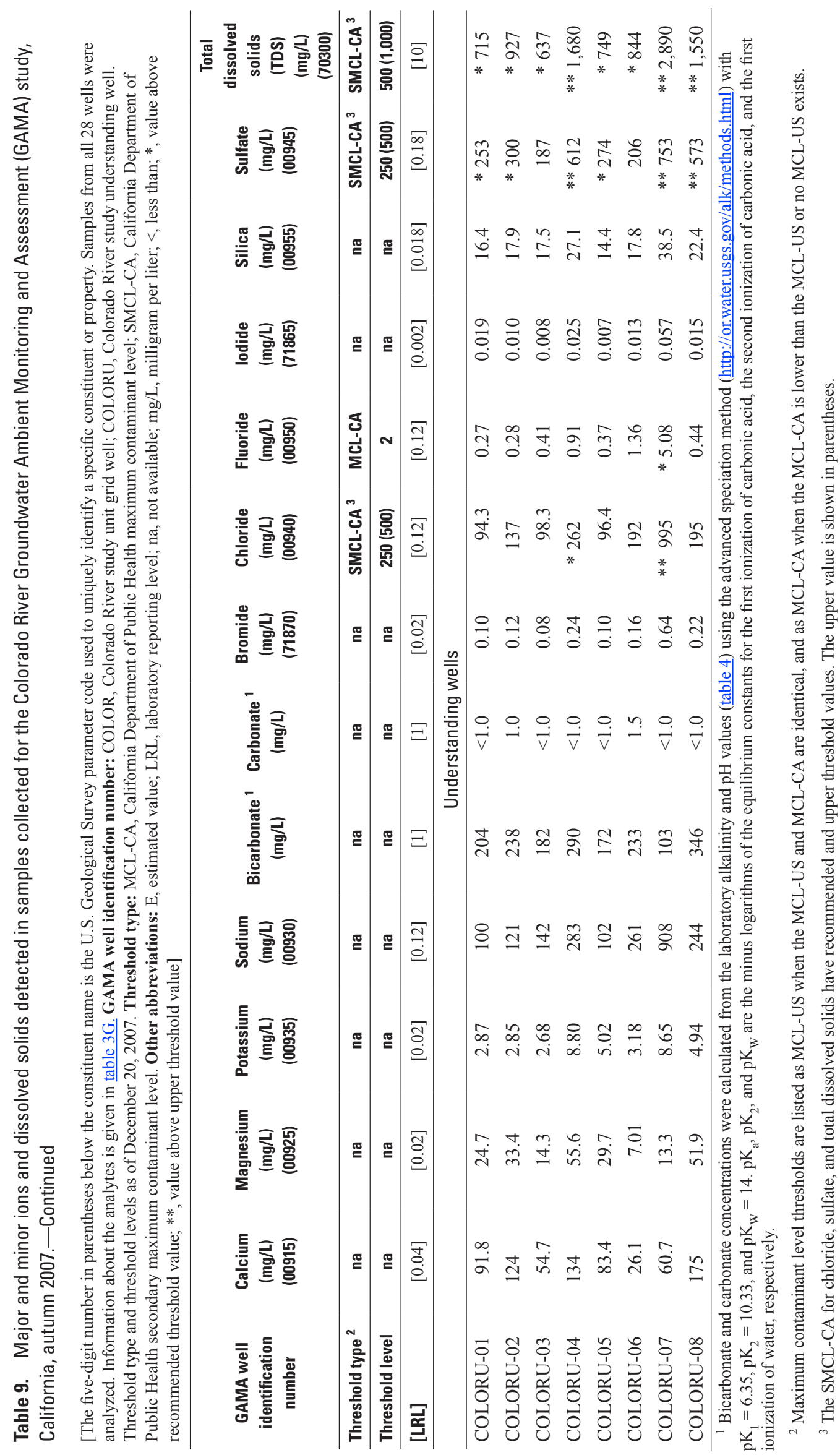


Table 10. Trace elements detected in groundwater samples collected for the Colorado River Groundwater Ambient Monitoring and Assessment (GAMA) study, California, autumn 2007.

[The five-digit number in parentheses below the constituent name is the U.S. Geological Survey parameter code used to uniquely identify a specific constituent or property. Samples from all 28 wells were analyzed. All analytes are listed in table 3G. Values less than the study reporting level are reported with a less than or equal to sign $(\leq)$. GAMA well identification number: COLOR, Colorado River study unit grid-well; COLORU, Colorado River study unit understanding well. Threshold type and threshold levels as of December 20, 2007. Threshold type: MCL-CA, California Department of Public Health maximum contaminant level; MCL-US, U.S. Environmental Protection Agency maximum contaminant level; NL-CA, California Department of Public Health notification level; HAL-US, U.S. Environmental Protection Agency lifetime health advisory level; SMCL-CA, California Department of Public Health secondary maximum contaminant level. Other abbreviations: LRL, laboratory reporting level; SRL, study reporting level; na, not available; E, estimated value; $\mu \mathrm{g} / \mathrm{L}$, microgram per liter; - , not detected; *, value above threshold value]

\begin{tabular}{|c|c|c|c|c|c|c|c|c|c|c|c|c|}
\hline $\begin{array}{c}\text { GAMA well } \\
\text { identification } \\
\text { number }\end{array}$ & $\begin{array}{c}\text { Aluminum } \\
(\mu \mathrm{g} / \mathrm{L}) \\
(01106)\end{array}$ & $\begin{array}{c}\text { Antimony } \\
\text { ( } \mu \mathrm{g} / \mathrm{L}) \\
(01095)\end{array}$ & $\begin{array}{c}\text { Arsenic } \\
(\mu \mathrm{g} / \mathrm{L}) \\
(01000)\end{array}$ & $\begin{array}{c}\text { Barium } \\
\text { ( } \mu \mathrm{g} / \mathrm{L}) \\
(01005)\end{array}$ & $\begin{array}{c}\text { Beryllium } \\
(\mu \mathrm{g} / \mathrm{L}) \\
(01010)\end{array}$ & $\begin{array}{c}\text { Boron } \\
(\mu \mathrm{g} / \mathrm{L}) \\
(01020) \\
\end{array}$ & $\begin{array}{c}\text { Cadmium } \\
\text { ( } \mu \mathrm{g} / \mathrm{L}) \\
(01025)\end{array}$ & $\begin{array}{c}\text { Chromium } \\
(\mu \mathrm{g} / \mathrm{L}) \\
(01030) \\
\end{array}$ & $\begin{array}{c}\text { Cobalt } \\
(\mu \mathrm{g} / \mathrm{L}) \\
(01035)\end{array}$ & $\begin{array}{c}\text { Copper } \\
(\mu \mathrm{g} / \mathrm{L}) \\
(01040)\end{array}$ & 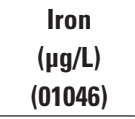 & $\begin{array}{c}\text { Lead } \\
\text { ( } \mu \mathrm{g} / \mathrm{L}) \\
(01049) \\
\end{array}$ \\
\hline Threshold type ${ }^{1}$ & MCL-CA & MCL-US & MCL-US & MCL-CA & MCL-US & NL-CA & MCL-US & MCL-CA & na & MCL-US & SMCL-CA & MCL-US \\
\hline [LRL] & {$[1.6]$} & [0.14] & {$[0.06]$} & {$[0.4]$} & {$[0.008]$} & [6] & {$[0.04]$} & {$[0.12]$} & {$[0.02]$} & [1] & [8] & {$[0.08]$} \\
\hline$[S R L]^{2,3}$ & {$[1.6]$} & - & - & [0.79] & - & - & - & {$[0.42]$} & - & [1.7] & [21] & ${ }^{3}[0.65]$ \\
\hline COLOR-02 & - & 0.2 & $* 11.1$ & 21 & E0.01 & 164 & - & 0.5 & 0.05 & 1.7 & $\leq 8$ & $\leq 0.15$ \\
\hline COLOR-03 & - & - & 0.2 & 174 & E0.01 & 196 & - & - & 0.07 & - & 197 & - \\
\hline COLOR-04 & - & - & 0.6 & 142 & - & 183 & - & - & 0.05 & - & * 419 & - \\
\hline COLOR-05 & $\leq 1.0$ & - & 0.1 & 81 & E0.01 & 132 & - & - & 0.05 & - & 75 & $\leq 0.06$ \\
\hline COLOR-06 & $\leq 1.0$ & - & 0.1 & 54 & - & 74 & - & - & 0.04 & - & 201 & $\leq 0.06$ \\
\hline COLOR-10 & - & - & 0.1 & 45 & 0.010 & 214 & E0.02 & $\leq 0.07$ & 0.05 & - & 206 & $\leq 0.05$ \\
\hline COLOR-11 & - & - & 4.6 & 37 & - & $* 1,020$ & - & 0.7 & 0.07 & - & - & $\leq 0.39$ \\
\hline COLOR-12 & 1.8 & - & 5.5 & 59 & - & 303 & E0.02 & 1.9 & E0.01 & 4.1 & - & $\leq 0.50$ \\
\hline COLOR-13 & $\leq 0.9$ & - & 7.2 & 169 & - & 310 & E0.04 & 9.9 & 0.02 & 1.7 & - & $\leq 0.63$ \\
\hline COLOR-14 & $\leq 1.1$ & - & 3.2 & 62 & - & 101 & - & - & 0.03 & 1.8 & - & $\leq 0.31$ \\
\hline COLOR-15 & - & - & 1.1 & 82 & - & - & E0.07 & $\leq 0.1$ & 0.23 & - & $* 1,080$ & $\leq 0.15$ \\
\hline COLOR-16 & $\leq 1.2$ & - & 0.2 & 94 & E0.01 & 116 & - & $\leq 0.08$ & 0.17 & - & 180 & - \\
\hline COLOR-17 & $\leq 1.3$ & - & 1.4 & 143 & E0.004 & 198 & - & 10.3 & 0.06 & - & $\leq 10$ & $\leq 0.05$ \\
\hline COLOR-18 & 3.0 & - & 2.8 & 25 & E0.004 & 388 & E0.03 & $\leq 0.3$ & 0.07 & $\leq 0.54$ & 66 & $\leq 0.26$ \\
\hline COLOR-19 & - & - & 0.5 & 108 & E0.02 & 202 & E0.06 & $\leq 0.2$ & 0.11 & 3.2 & $* 863$ & $\leq 0.26$ \\
\hline COLORU-06 & 2.2 & - & 3.7 & 27 & - & 167 & - & 0.5 & E0.01 & - & $\leq 10$ & $\leq 0.20$ \\
\hline COLORU-07 & - & - & $* 36.2$ & 19 & - & $* 2,180$ & E0.07 & 0.9 & - & - & 25 & - \\
\hline COLORU-08 & - & - & 0.7 & 195 & - & 408 & E0.08 & - & 0.20 & - & * 905 & - \\
\hline
\end{tabular}


Table 10. Trace elements detected in groundwater samples collected for the Colorado River Groundwater Ambient Monitoring and Assessment (GAMA) study, California, autumn 2007.-Continued

[The five-digit number in parentheses below the constituent name is the U.S. Geological Survey parameter code used to uniquely identify a specific constituent or property. Samples from all 28 wells were analyzed. All analytes are listed in table 3G. Values less than the study reporting level are reported with a less than or equal to sign $(\leq)$. GAMA well identification number: COLOR, Colorado River study unit grid-well; COLORU, Colorado River study unit understanding well; Threshold type and threshold levels as of December 20, 2007. Threshold type: MCL-CA; California Department of Public Health maximum contaminant level; MCL-US, U.S. Environmental Protection Agency maximum contaminant level; NL-CA, California Department of Public Health notification level; AL-US, U.S. Environmental Protection Agency action level; HAL-US, U.S. Environmental Protection Agency lifetime health advisory level; SMCL-CA, California Department of Public Health secondary maximum contaminant level. Other abbreviations: LRL, laboratory reporting level; SRL, study reporting level; na, not available; E, estimated value; $\mu \mathrm{g} / \mathrm{L}$, microgram per liter; - , not detected; $\leq$, less than or equal to; *, value above threshold value]

\begin{tabular}{|c|c|c|c|c|c|c|c|c|c|c|c|c|}
\hline $\begin{array}{c}\text { GAMA well } \\
\text { identification } \\
\text { number }\end{array}$ & $\begin{array}{c}\text { Lithium } \\
(\mu \mathrm{g} / \mathrm{L}) \\
(01130)\end{array}$ & $\begin{array}{c}\text { Manga- } \\
\text { nese } \\
(\mu \mathrm{g} / \mathrm{L}) \\
(01056)\end{array}$ & $\begin{array}{l}\text { Mercury } \\
(\mu \mathrm{g} / \mathrm{L}) \\
(71890)\end{array}$ & $\begin{array}{c}\text { Molybde- } \\
\text { num } \\
(\mu \mathrm{g} / \mathrm{L}) \\
(01060)\end{array}$ & $\begin{array}{c}\text { Nickel } \\
(\mu \mathrm{g} / \mathrm{L}) \\
(01065)\end{array}$ & $\begin{array}{c}\text { Selenium } \\
(\mu \mathrm{g} / \mathrm{L}) \\
(01145)\end{array}$ & $\begin{array}{c}\text { Strontium } \\
(\mu \mathrm{g} / \mathrm{L}) \\
(01080)\end{array}$ & $\begin{array}{c}\text { Thallium } \\
\text { ( } \mu \mathrm{g} / \mathrm{L}) \\
(01057)\end{array}$ & $\begin{array}{c}\text { Tungsten } \\
(\mu \mathrm{g} / \mathrm{L}) \\
(01155)\end{array}$ & $\begin{array}{c}\text { Uranium } \\
\text { ( } \mu \mathrm{g} / \mathrm{L}) \\
(22703)\end{array}$ & $\begin{array}{c}\text { Vanadium } \\
(\mu \mathrm{g} / \mathrm{L}) \\
(01085)\end{array}$ & $\begin{array}{c}\text { Zinc } \\
(\mu \mathrm{g} / \mathrm{L}) \\
(01090)\end{array}$ \\
\hline Threshold level & na & 50 & 2 & 40 & 100 & 50 & 4,000 & 2 & na & 30 & 50 & 5,000 \\
\hline [LRL] & [1] & {$[0.2]$} & {$[0.01]$} & {$[0.2]$} & {$[0.2]$} & {$[0.04]$} & {$[0.8]$} & {$[0.04]$} & {$[0.06]$} & {$[0.02]$} & {$[0.04]$} & {$[1.8]$} \\
\hline$[\mathrm{SRL}]^{2,3}$ & - & {$[0.2]$} & [0.012] & - & {$[0.36]$} & - & [0.99] & - & [0.11] & - & [0.1] & [4.8] \\
\hline COLOR-01 & 37.5 & 0.3 & - & 5.8 & 0.56 & 1.80 & 960 & - & 0.47 & 6.52 & 1.2 & 15.6 \\
\hline COLOR-02 & 74.2 & E0.4 & $\leq 0.007$ & 7.5 & 0.40 & 1.50 & 800 & - & 1.1 & 8.83 & 5.4 & 12.1 \\
\hline COLOR-03 & 47.4 & $* 1,110$ & - & 3.9 & 0.42 & 0.04 & 1,360 & - & 0.29 & 1.02 & 0.3 & $\leq 1.3$ \\
\hline COLOR-04 & 57.7 & $* 157$ & $\leq 0.008$ & 2.1 & 0.47 & 0.11 & 1,570 & E0.03 & 0.97 & 0.27 & 0.4 & - \\
\hline COLOR-05 & 49.5 & $* 241$ & 0.013 & 3.8 & 0.44 & 0.04 & 2,030 & - & $\leq 0.05$ & 0.18 & 0.1 & $\leq 1.7$ \\
\hline COLOR-09 & 96.2 & 21.1 & 0.015 & 13.3 & 1.6 & E0.03 & 1,020 & - & 1.3 & 0.04 & 0.3 & $\leq 2.6$ \\
\hline COLOR-10 & 74.8 & * 276 & $\leq 0.010$ & 9.6 & 0.51 & 0.05 & 1,560 & - & $\leq 0.04$ & 0.37 & 0.2 & 18.9 \\
\hline COLOR-11 & 263 & 1.6 & 0.013 & 3.7 & 0.76 & 2.30 & $* 4,660$ & - & - & $* 45.4$ & 12.6 & - \\
\hline COLOR-12 & 50.1 & - & - & 13.7 & $\leq 0.21$ & 2.50 & 1,290 & - & 0.12 & 4.9 & 9.2 & 14.1 \\
\hline COLOR-13 & 53.6 & - & $\leq 0.006$ & 8.5 & $\leq 0.43$ & 1.20 & 1,220 & - & 0.78 & 6.35 & 12.9 & $\leq 2.9$ \\
\hline COLOR-14 & 24.3 & 3.6 & $\leq 0.010$ & 3.9 & 0.36 & 0.05 & 1,080 & - & 0.95 & 6.58 & 1.9 & 28.8 \\
\hline COLOR-15 & - & * 898 & $\leq 0.006$ & 31.3 & 3.9 & 0.20 & $* 4,710$ & - & 0.14 & 1.11 & 0.7 & $\leq 4.3$ \\
\hline COLOR-16 & 51.5 & * 640 & - & 1.9 & 2.8 & 0.06 & 2,600 & - & $\leq 0.08$ & 1.53 & 0.4 & - \\
\hline COLOR-17 & 77.5 & 0.5 & $\leq 0.008$ & 6.2 & 1.1 & 1.90 & 2,520 & - & 5.7 & 1.55 & 9.3 & 8.2 \\
\hline COLOR-18 & 87.9 & 11.2 & $\leq 0.006$ & 15.8 & 0.71 & 8.60 & 1,140 & - & 0.21 & 2.0 & 2.2 & $\leq 3.1$ \\
\hline COLOR-19 & 89.9 & $* 1,150$ & - & 5.2 & 1.1 & - & 2,640 & - & 0.35 & 0.93 & 0.3 & 7.7 \\
\hline COLORU-05 & 39.6 & $* 99.0$ & 0.019 & 5.2 & 0.53 & 2.20 & 1,170 & - & 0.15 & 4.74 & 1.6 & $\leq 0.91$ \\
\hline COLORU-06 & 93.0 & 5.9 & $\leq 0.010$ & 5.8 & $\leq 0.11$ & 0.48 & 630 & - & 0.35 & 1.73 & 1.0 & $\leq 2.4$ \\
\hline COLORU-07 & 817 & 6.1 & 0.016 & 31.3 & - & 2.60 & 1,660 & - & 2.1 & 1.21 & 6.8 & $\leq 2.7$ \\
\hline COLORU-08 & 106 & * 949 & $\leq 0.007$ & 33.2 & 1.8 & 0.13 & 1,640 & - & 0.35 & 0.77 & 0.7 & 15.6 \\
\hline
\end{tabular}

\footnotetext{
${ }^{1}$ Maximum contaminant level thresholds are listed as MCL-US when the MCL-US and MCL-CA are identical, and as MCL-CA when the MCL-CA is lower than the MCL-US or no MCL-US exists.

${ }^{2}$ Study reporting levels (SRL) were defined on the basis of the examination of field blanks collected in GAMA study units from May 2004 through January 2008 (L.D. Olsen and M.S. Fram, U.S. Geological Survey, unpublished data, 2008).

${ }^{3}$ Values equal to or less than the SRL are reported as less than or equal to the value reported by the laboratory $(\leq)$. Values reported with a $\leq$ symbol in this table have the following field comment included in the USGS NWIS database: Result is $<$ or $\leq$ reported value, based on quality control data (including but not limited to field blanks, source-solution blanks, trip blanks, NWQL set blanks, NWQL blank water certificates, and BQS Blind Blank Program data).
} 
Table 11. Species of inorganic iron, arsenic, and chromium detected in samples collected for the Colorado River Groundwater Ambient Monitoring and Assessment (GAMA) study, California, autumn 2007.

[Data in this table were analyzed at U.S. Geological Survey (USGS) Trace Metal Laboratory in Boulder, Colorado, using research methods and are not stored in the USGS National Water Information System database. Samples from all 28 wells were analyzed for iron, arsenic, and chromium species; only wells with at least one detection are listed. Information about the analytes is given in table $3 \mathrm{H}$. GAMA well identification number: COLOR, Colorado River study unit grid well; COLORU, Colorado River study unit understanding well. Threshold types and threshold levels as of December 20, 2007. Threshold type: MCL-CA, California Department of Public Health maximum contaminant level; MCL-US, U.S. Environmental Protection Agency maximum contaminant level; SMCL-CA, California Department of Public Health secondary maximum contaminant level. Other abbreviations: MDL, method detection limit; na, not available; $\mu \mathrm{g} / \mathrm{L}$, microgram per liter; nc, not collected; - , not detected; *, value above threshold value]

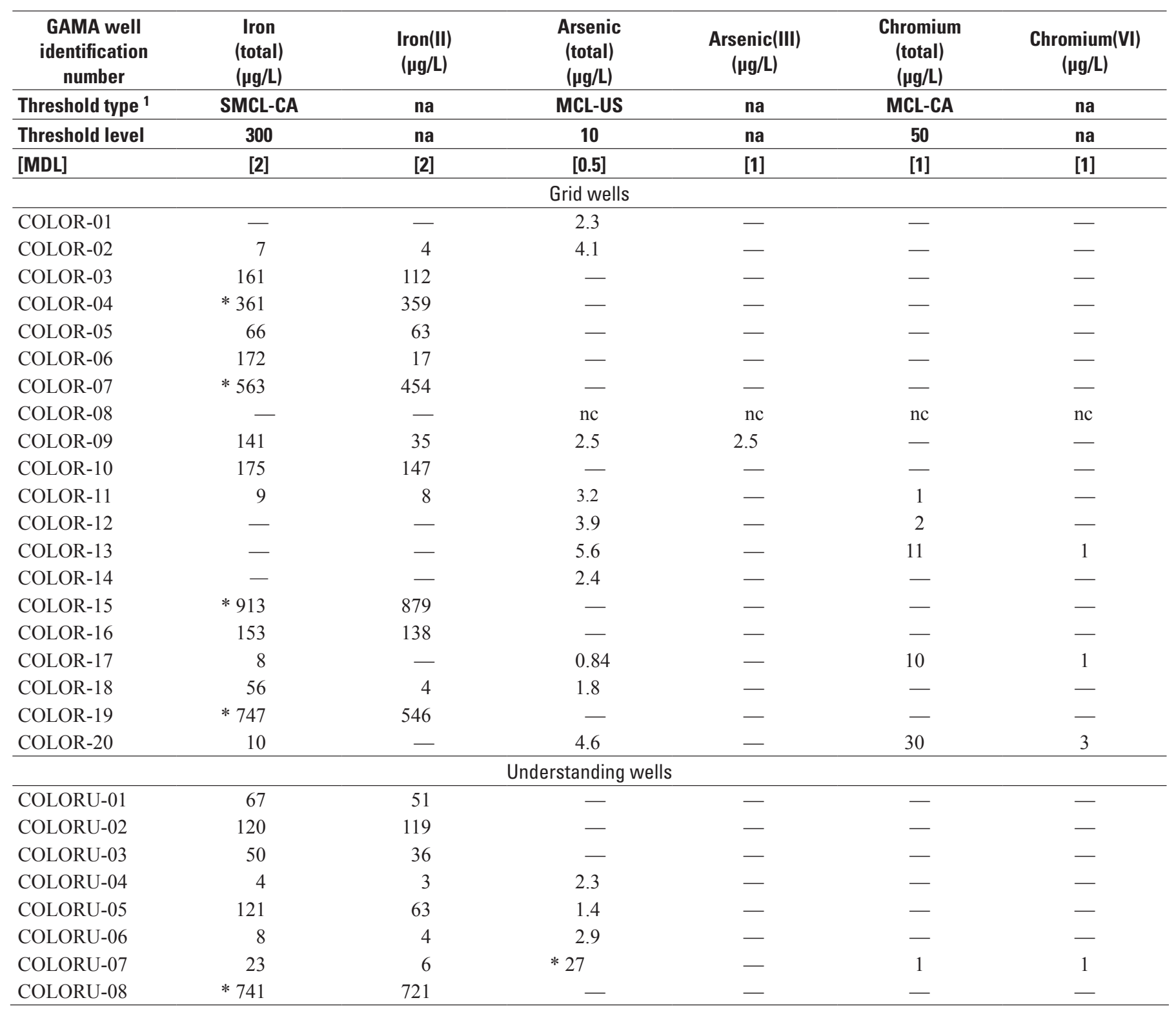

${ }^{1}$ Maximum contaminant level thresholds are listed as MCL-US when the MCL-US and MCL-CA are identical, and as MCL-CA when the MCL-CA is lower than the MCL-US or no MCL-US exists. 
Table 12. Stable isotope ratios and activities of tritium and carbon-14 detected in samples collected for the Colorado River Groundwater Ambient Monitoring and Assessment (GAMA) study, California, autumn 2007.

[The five-digit number in parentheses below the constituent name is the U.S. Geological Survey parameter code used to uniquely identify a specific constituent or property. Samples from all 52 wells were analyzed. Information about the analytes is given in table 3I. Samples from all 28 wells were analyzed. Stable isotope ratios are reported in the standard delta notation $(\delta)$, the ratio of a heavier isotope to the more common lighter isotope of that element, relative to a standard reference material. GAMA well identification number: COLOR, Colorado River study unit grid well; COLORU, Colorado River study unit understanding well. Threshold types and threshold levels as of December 20, 2007. Threshold type: MCL-CA, California Department of Public Health maximum contaminant level. Other abbreviations: $\mathrm{H}$, hydrogen; $\mathrm{O}$, oxygen; $\mathrm{C}$, carbon; $\mathrm{pCi} / \mathrm{L}$, picocurie per liter; na, not applicable; - , not detected]

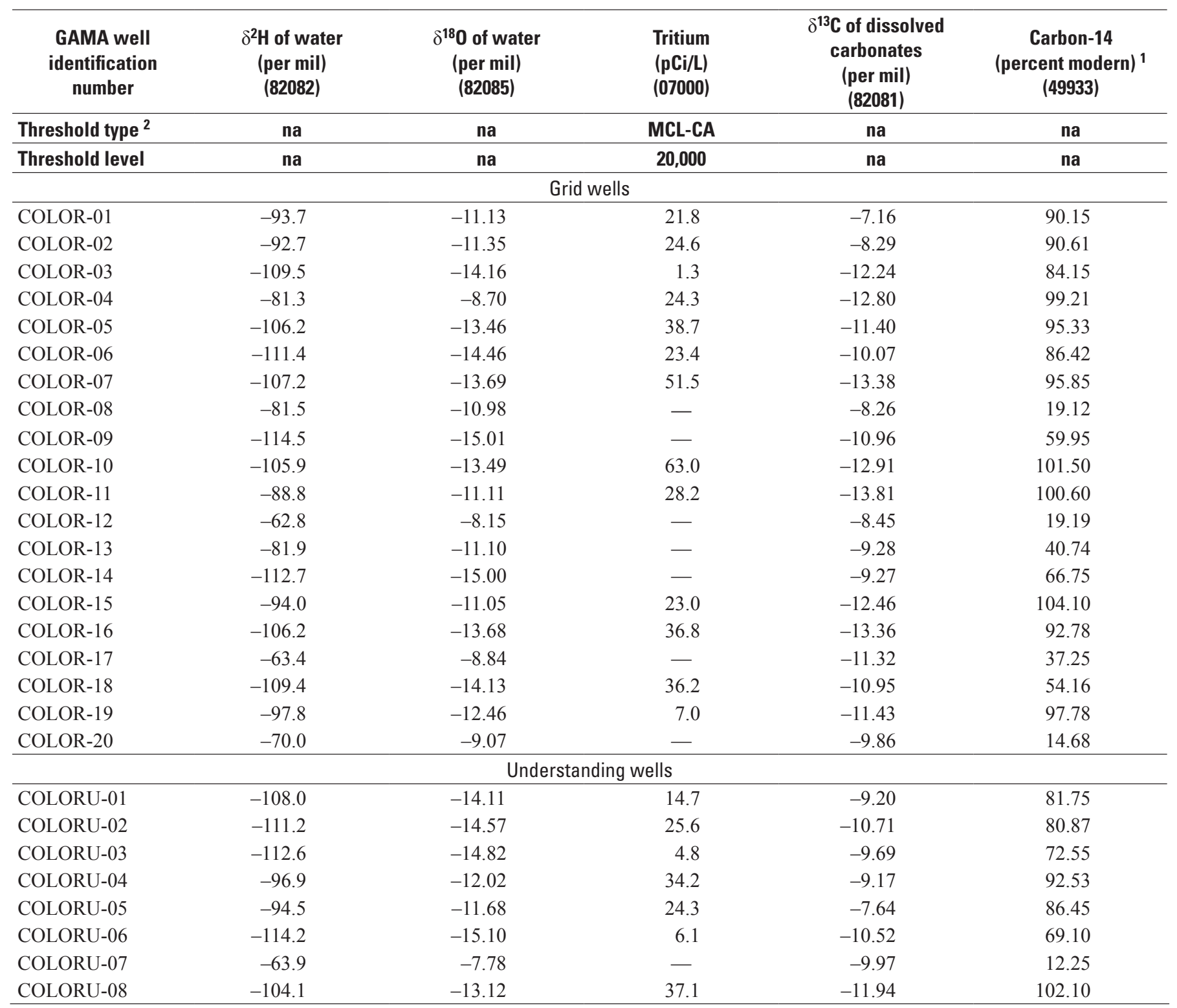

\footnotetext{
${ }^{1} 100$-percent modern carbon is referenced to atmospheric carbon-14 production rates in 1950. Values of percent modern carbon can be greater than 100 percent because the atmospheric production rate was much higher during the period of above-ground nuclear testing in the 1950s and 1960s.

${ }^{2}$ Maximum contaminant level thresholds are listed as MCL-US when the MCL-US and MCL-CA are identical, and as MCL-CA when the MCL-CA is lower than the MCL-US or no MCL-US exists.
} 
Table 13A. Radium isotopes detected in samples collected for the Colorado River Groundwater Ambient Monitoring and Assessment (GAMA) study, California, autumn 2007.

[The five-digit number in parentheses below the constituent name is the U.S. Geological Survey parameter code used to uniquely identify a specific constituent or property. Information about the analytes is given in table 3I. Samples from all 28 wells were analyzed, but only samples with detections are listed. Measured values less than the sample-specific critical level $\left(\mathrm{ssL}_{\mathrm{C}}\right)$ are reported as nondetections $(-)$. GAMA well identification number: COLOR, Colorado River study area grid well; COLORU, Colorado River study area understanding well. Thresholds and threshold values as of December 20, 2007. Threshold type: MCL-US, U.S. Environmental Protection Agency maximum contaminant level. Other abbreviations: CSU, 1-sigma combined standard uncertainty; $\mathrm{pCi} / \mathrm{L}$, picocurie per liter]

\begin{tabular}{|c|c|c|c|c|}
\hline $\begin{array}{c}\text { GAMA well } \\
\text { identification number }\end{array}$ & \multicolumn{2}{|c|}{$\begin{array}{c}\text { Radium-226 } \\
\text { (pCi/L) } \\
(09511)\end{array}$} & \multicolumn{2}{|c|}{$\begin{array}{c}\text { Radium-228 } \\
\text { (pCi/L) } \\
\text { (81366) }\end{array}$} \\
\hline Threshold type ${ }^{1}$ & \multicolumn{2}{|c|}{ MCL-CA } & \multicolumn{2}{|c|}{ MCL-CA } \\
\hline Threshold level & \multicolumn{2}{|c|}{25} & \multicolumn{2}{|c|}{25} \\
\hline Reporting level method & Result \pm CSU & ssL $_{\mathrm{c}}$ & Result \pm CSU & ssL $_{c}$ \\
\hline \multicolumn{5}{|c|}{ Grid wells } \\
\hline$\overline{\text { COLOR-01 }}$ & $0.062 \pm 0.013$ & 0.014 & $0.324 \pm 0.095$ & 0.21 \\
\hline COLOR-02 & $0.060 \pm 0.013$ & 0.014 & - & 0.28 \\
\hline COLOR-03 & $0.502 \pm 0.033$ & 0.013 & $0.405 \pm 0.091$ & 0.20 \\
\hline COLOR-04 & $0.072 \pm 0.012$ & 0.012 & $0.200 \pm 0.085$ & 0.20 \\
\hline COLOR-05 & $0.490 \pm 0.031$ & 0.014 & $0.39 \pm 0.09$ & 0.21 \\
\hline COLOR-06 & $0.188 \pm 0.023$ & 0.016 & $0.25 \pm 0.14$ & 0.20 \\
\hline COLOR-07 & $1.218 \pm 0.063$ & 0.016 & $0.6 \pm 0.1$ & 0.23 \\
\hline COLOR-08 & $0.092 \pm 0.015$ & 0.013 & - & 0.22 \\
\hline COLOR-09 & $0.101 \pm 0.016$ & 0.015 & $0.19 \pm 0.17$ & 0.16 \\
\hline COLOR-10 & $0.235 \pm 0.023$ & 0.016 & $0.44 \pm 0.18$ & 0.16 \\
\hline COLOR-11 & $0.120 \pm 0.018$ & 0.017 & $0.67 \pm 0.19$ & 0.18 \\
\hline COLOR-12 & $0.057 \pm 0.012$ & 0.014 & - & 0.19 \\
\hline COLOR-13 & $0.086 \pm 0.014$ & 0.015 & $0.297 \pm 0.065$ & 0.16 \\
\hline COLOR-14 & $0.140 \pm 0.019$ & 0.016 & $0.327 \pm 0.075$ & 0.18 \\
\hline COLOR-15 & $0.043 \pm 0.014$ & 0.016 & $0.24 \pm 0.08$ & 0.19 \\
\hline COLOR-16 & $0.837 \pm 0.046$ & 0.018 & $0.53 \pm 0.12$ & 0.27 \\
\hline COLOR-17 & $0.560 \pm 0.013$ & 0.016 & $0.34 \pm 0.18$ & 0.30 \\
\hline COLOR-18 & $0.104 \pm 0.019$ & 0.017 & $0.26 \pm 0.11$ & 0.25 \\
\hline COLOR-19 & $0.226 \pm 0.024$ & 0.018 & $0.72 \pm 0.11$ & 0.23 \\
\hline COLOR-20 & $0.028 \pm 0.013$ & 0.018 & - & 0.22 \\
\hline \multicolumn{5}{|c|}{ Understanding wells } \\
\hline COLORU-01 & $0.296 \pm 0.024$ & 0.013 & $0.26 \pm 0.13$ & 0.26 \\
\hline COLORU-02 & $0.357 \pm 0.024$ & 0.014 & $0.305 \pm 0.095$ & 0.20 \\
\hline COLORU-03 & $0.123 \pm 0.016$ & 0.016 & $0.230 \pm 0.095$ & 0.21 \\
\hline COLORU-04 & $0.079 \pm 0.016$ & 0.017 & $0.263 \pm 0.095$ & 0.22 \\
\hline COLORU-05 & $0.024 \pm 0.011$ & 0.016 & $0.286 \pm 0.09$ & 0.22 \\
\hline COLORU-06 & $0.090 \pm 0.019$ & 0.015 & - & 0.29 \\
\hline COLORU-07 & $0.147 \pm 0.019$ & 0.016 & $0.28 \pm 0.16$ & 0.15 \\
\hline COLORU-08 & $0.108 \pm 0.017$ & 0.018 & $0.37 \pm 0.09$ & 0.20 \\
\hline
\end{tabular}

${ }^{1}$ Maximum contaminant level thresholds are listed as MCL-US when the MCL-US and MCL-CA are identical, and as MCL-CA when the MCL-CA is lower than the MCL-US or no MCL-US exists.

${ }^{2}$ The MCL-US threshold for radium is the sum of those for radium-226 and radium-228. 
Table 13B. Gross alpha and gross beta radioactivity detected in samples collected for the Colorado River Groundwater Ambient Monitoring and Assessment (GAMA) study, California, autumn 2007.

[The five-digit number in parentheses below the constituent name is the U.S. Geological Survey parameter code used to uniquely identify a specific constituent or property. Information about the analytes is given in table 3I. Samples from all 28 wells were analyzed, but only samples with detections are listed. The reference nuclide for measurement of gross alpha particle activity is thorium-230 and the reference nuclide for measuring gross beta particle activity is cesium-137. Measured values less than the sample-specific critical level ( $\mathrm{ssL}_{\mathrm{C}}$ ) are reported as nondetections (-). GAMA well identification number: COLOR, Colorado River study area grid well; COLORU, Colorado River study area understanding well. Thresholds and threshold values as of December 20, 2007. Threshold type: MCL-CA, California Department of Public Health maximum contaminant level; MCL-US, U.S. Environmental Protection Agency maximum contaminant level. Other abbreviations: CSU, 1-sigma combined standard uncertainty; pCi/L, picocurie per liter; *, result above threshold value; \pm , plus or minus]

\begin{tabular}{|c|c|c|c|c|c|c|c|c|}
\hline \multirow{2}{*}{\begin{tabular}{l}
\multicolumn{1}{c}{ GAMA well } \\
identification number \\
Threshold type $^{1}$
\end{tabular}} & \multicolumn{2}{|c|}{$\begin{array}{l}\text { Gross alpha } \\
\text { particle activity, } \\
\text { 72-hour count } \\
\text { (pCi/L) } \\
\text { (62636) }\end{array}$} & \multicolumn{2}{|c|}{$\begin{array}{c}\text { Gross alpha } \\
\text { particle activity, } \\
\text { 30-day count } \\
\text { (pCi/L) } \\
\text { (62639) }\end{array}$} & \multicolumn{2}{|c|}{$\begin{array}{c}\text { Gross beta } \\
\text { particle activity, } \\
\text { 72-hour count } \\
\text { (pCi/L) } \\
\text { (62642) }\end{array}$} & \multicolumn{2}{|c|}{$\begin{array}{c}\text { Gross beta } \\
\text { particle activity, } \\
\text { 30-day count } \\
\text { (pCi/L) } \\
\text { (62645) }\end{array}$} \\
\hline & MCL-US & & MCL-US & & MCL-CA & & MCL-CA & \\
\hline Threshold value & 15 & & 15 & & 50 & & 50 & \\
\hline COLOR-01 & - & 2.3 & $5.3 \pm 1.5$ & 1.4 & $5.93 \pm 0.76$ & 0.64 & $5.87 \pm 0.73$ & 0.59 \\
\hline COLOR-02 & $* 20.3 \pm 3.3$ & 2.6 & $13.3 \pm 2.5$ & 2.2 & $5.09 \pm 0.83$ & 0.99 & $7.41 \pm 0.99$ & 0.97 \\
\hline COLOR-03 & - & 5.2 & - & 4 & $8.5 \pm 1.2$ & 1.1 & $7.2 \pm 1$ & 1.1 \\
\hline COLOR-04 & - & 3.1 & - & 2.5 & $7.43 \pm 0.96$ & 0.84 & $7.6 \pm 1.1$ & 1.3 \\
\hline COLOR-08 & - & 3.3 & - & 2.8 & $3.82 \pm 0.93$ & 1.3 & $5.4 \pm 1.1$ & 1.5 \\
\hline COLOR-09 & - & 3.9 & - & 3.3 & $4.39 \pm 0.74$ & 0.86 & $3.74 \pm 0.71$ & 0.9 \\
\hline COLOR-10 & - & 4.4 & - & 3.8 & $3.41 \pm 0.65$ & 0.85 & $3.94 \pm 0.68$ & 0.84 \\
\hline COLOR-11 & * $57 \pm 10$ & 8.9 & $* 52.2 \pm 9.0$ & 3.68 & $7.5 \pm 1.6$ & 2.1 & $12.8 \pm 2.6$ & 3.6 \\
\hline COLOR-12 & $3.0 \pm 1.1$ & 1.3 & $2.0 \pm 1.2$ & 1.7 & $3.58 \pm 0.57$ & 0.63 & $5 \pm 0.68$ & 0.62 \\
\hline COLOR-13 & $9.1 \pm 1.9$ & 2.1 & $2.9 \pm 1.0$ & 1.2 & $7.7 \pm 1.1$ & 1.2 & $11.4 \pm 1.3$ & 0.72 \\
\hline COLOR-14 & $10.3 \pm 1.8$ & 1.3 & $9.9 \pm 1.8$ & 1.5 & $3.69 \pm 0.68$ & 0.929 & $5.74 \pm 0.7$ & 1 \\
\hline COLOR-15 & - & 3.4 & - & 6.6 & $5 \pm 1.4$ & 2.1 & $7.7 \pm 1.1$ & 1.2 \\
\hline COLOR-16 & $5.1 \pm 3.2$ & 4.3 & - & 3.3 & $5.32 \pm 0.92$ & 1 & $6.8 \pm 1.2$ & 1.5 \\
\hline COLOR-17 & $3.5 \pm 2.0$ & 2.6 & - & 1.8 & $5.86 \pm 0.73$ & 0.55 & $4.92 \pm 0.78$ & 0.95 \\
\hline COLORU-03 & - & 2.3 & - & 1.8 & $3.01 \pm 0.72$ & 1 & $2.83 \pm 0.71$ & 1 \\
\hline COLORU-04 & * $19.1 \pm 3.8$ & 2.9 & - & 4.3 & $8.3 \pm 1.3$ & 1.3 & $11.5 \pm 1.4$ & 1.2 \\
\hline COLORU-05 & $6.3 \pm 1.5$ & 1.4 & - & 2.4 & $6.4 \pm 1$ & 1.1 & $6.72 \pm 0.94$ & 0.96 \\
\hline COLORU-06 & $6.4 \pm 2.2$ & 2.5 & - & 3.4 & $1.42 \pm 0.62$ & 1 & $2.35 \pm 0.74$ & 1.1 \\
\hline COLORU-07 & - & 6.8 & - & 12 & $6.5 \pm 1.7$ & 2.5 & $9.5 \pm 1.9$ & 2.5 \\
\hline COLORU-08 & - & 5.3 & - & 3.4 & $4.4 \pm 1$ & ${ }^{3} 1.5$ & $4.1 \pm 1$ & 1.6 \\
\hline
\end{tabular}

\footnotetext{
${ }^{1}$ Maximum contaminant level thresholds are listed as MCL-US when the MCL-US and MCL-CA are identical, and as MCL-CA when the MCL-CA is lower
} than the MCL-US or no MCL-US exists.

2 72-hour holding time exceeded by 1 day.

3 72-hour holding time exceeded by 3 days. 
Table 13C. Radon-222 detected in samples collected for the Colorado River Groundwater Ambient Monitoring and Assessment (GAMA) study, California, autumn 2007.

[The five-digit number in parentheses below the constituent name is the U.S. Geological Survey parameter code used to uniquely identify a specific constituent or property. Table 3I contains additional information about the analytes. Samples from all 28 wells were analyzed, but only samples with detections are listed. GAMA well identification number: COLOR, Colorado River study area grid well; COLORU, Colorado River study area understanding well. Threshold type and threshold level as of December 20, 2007. Threshold type: MCL-US, U.S. Environmental Protection Agency maximum contaminant level. Other abbreviations: 2CSU, 2-sigma combined standard uncertainty; $\mathrm{pCi} / \mathrm{L}$, picocurie per liter; *, result above threshold value; na, not available]

\begin{tabular}{|c|c|c|c|}
\hline $\begin{array}{l}\text { GAMA well } \\
\text { identification number }\end{array}$ & $\begin{array}{c}\text { Radon-222 } \\
\text { (pCi/L) } \\
(82303)\end{array}$ & $\begin{array}{c}\text { GAMA well } \\
\text { identification } \\
\text { number }\end{array}$ & $\begin{array}{c}\text { Radon-222 } \\
\text { (pCi/L) } \\
(82303)\end{array}$ \\
\hline Threshold value & 25 & Threshold value & 25 \\
\hline Reporting level method & Result \pm CSU & Reporting level method & Result \pm CSU \\
\hline COLOR-02 & $* 440 \pm 24$ & COLOR-17 & $* 460 \pm 26$ \\
\hline COLOR-03 & $* 1,230 \pm 33$ & COLOR-18 & * $760 \pm 29$ \\
\hline COLOR-04 & $160 \pm 19$ & COLOR-19 & na \\
\hline COLOR-05 & $* 1,040 \pm 35$ & COLOR-20 & $* 670 \pm 28$ \\
\hline COLOR-09 & $* 560 \pm 28$ & COLORU-03 & $* 1,050 \pm 33$ \\
\hline COLOR-10 & $* 690 \pm 28$ & COLORU-04 & $250 \pm 19$ \\
\hline COLOR-11 & $280 \pm 19$ & COLORU-05 & $270 \pm 20$ \\
\hline COLOR-12 & $* 1,090 \pm 31$ & COLORU-06 & $* 580 \pm 28$ \\
\hline COLOR-13 & $260 \pm 18$ & COLORU-07 & $* 950 \pm 31$ \\
\hline COLOR-14 & $260 \pm 20$ & COLORU-08 & $160 \pm 17$ \\
\hline
\end{tabular}

COLOR-15

$300 \pm 19$

\footnotetext{
${ }^{1}$ Maximum contaminant level thresholds are listed as MCL-US when the MCL-US and MCL-CA are identical, and as MCL-CA when the MCL-CA is lower than the MCL-US or no MCL-US exists.

${ }^{2}$ The MCL-US threshold for radium is the sum of those for radium-226 and radium-228.
} 


\section{Appendix}

This appendix includes discussions of the methods used to collect and analyze groundwater samples and report the resulting water-quality data. These methods were selected to obtain representative samples of the groundwater from each well, and to minimize the potential for contamination of the samples or for bias in the data. Procedures used to collect and assess quality-control data and the results of the quality-control assessments are also discussed.

\section{Sample Collection and Analysis}

Groundwater samples were collected using standard and modified USGS protocols from the USGS NAWQA program (Koterba and others, 1995) and the USGS National Field Manual (U.S. Geological Survey, variously dated), and protocols described by Weiss (1968), Shelton and others (2001), Ball and McClesky (2003a,b), and Wright and others (2005).

Before being sampled, each well was pumped continuously in order to purge at least 3 casing-volumes of water from the well (Wilde and others, 1999). Wells were sampled using Teflon tubing with brass and stainless-steel fittings attached to a sampling point on the well discharge pipe as close to the well as possible. The sampling point was always located upstream of any active well-head treatment system or storage tank. If a chlorinating system was attached to the well, the chlorinator was shut off before purging and sampling the well in order to clear all chlorine out of the system. Samples were collected inside an enclosed chamber located within a mobile laboratory and connected to the well head by a 10- to 50-foot length of Teflon tubing (Lane and others, 2003). All fittings and lengths of tubing were cleaned after each sample was collected (Wilde, 2004).

For field measurements, groundwater was pumped through a flow-through chamber fitted with a multi-probe meter that simultaneously measured the water-quality indicators - dissolved oxygen, temperature, $\mathrm{pH}$, and specific conductance. Field measurements were made in accordance with protocols in the USGS National Field Manual (Wilde and Radtke, 2005; Wilde, 2006; Lewis, 2006; Radtke and others, 2005; Wilde and others, 2006). All sensors on the multiprobe meter were calibrated daily. Measured temperature, dissolved oxygen, $\mathrm{pH}$, and specific conductance values were recorded at 5-minute intervals for at least 30 minutes, and after these values remained stable for 20 minutes, samples to be analyzed in a laboratory were collected. Field measurements and instrument calibrations were recorded by hand on field record sheets and electronically in PCFF-GAMA, a software package designed by the USGS with support from the GAMA program. Analytical service requests were also managed by PCFF-GAMA. Information from PCFF-GAMA was uploaded directly into NWIS after samples were collected each week.
For analyses requiring filtered water, groundwater was diverted through a $0.45-\mu \mathrm{m}$ pore size vented capsule filter, a disk filter, or a baked glass-fiber filter, depending on the protocol for the analysis (Wilde and others, 1999; Wilde and others, 2004). Before samples were collected, polyethylene sample bottles were pre-rinsed two times with deionized water and then once with sample water. Samples requiring acidification were acidified to a $\mathrm{pH}$ of 2 or less with the appropriate acids using ampoules of certified, traceable concentrated acids obtained from the USGS National Water Quality Laboratory (NWQL).

Temperature-sensitive samples were stored on ice before and while they were shipped daily to various laboratories. The non-temperature sensitive samples to be analyzed for tritium, noble gases, chromium speciation, and stable isotopes of hydrogen and oxygen of water were shipped monthly. Volatile organic compounds, pesticides, and constituents of special interest are temperature sensitive and were shipped daily. Radium isotopes, gross alpha and gross beta radioactivity, and radon-222 samples are not temperature sensitive and were shipped daily.

Detailed sampling protocols for individual analyses and groups of analytes are described by Koterba and others (1995), in the USGS National Field Manual (Wilde and others, 1999; Wilde and others, 2004), and in the references for analytical methods listed in table A1; only brief descriptions are given here. Volatile organic compounds (VOC) and 1,2.3-trichloropropane (1,2,3-TCP) samples were collected in $40-\mathrm{mL}$ sample vials that were purged with three vial volumes of sample water before bottom-filling to eliminate atmospheric contamination. Six normal (6 N) hydrochloric acid (HCL) was added as a preservative to the VOC samples but not to the 1,2,3-TCP samples. Perchlorate samples to be analyzed at the Montgomery Watson Harza Laboratory (MWH ) were collected in $125-\mathrm{mL}$ polyethylene bottles. Perchlorate samples to be analyzed at Weck Laboratories, Inc. (WECK ) were collected each into a half-pint plastic bottle and then filtered through a rinsed syringe and $20-\mu \mathrm{m}$ disk filter into a sterilized 125-mL bottle. Samples to be analyzed for 1,4-dIoxane at MWH and WECK were collected in two pre-preserved 1-L glass amber bottles. Tritium samples were collected by bottom-filling two 1-L polyethylene bottles with unfiltered groundwater after overfilling each bottle with three volumes of water. Samples to be analyzed for stable isotopes of hydrogen and oxygen of water were collected in $60-\mathrm{mL}$ clear glass bottles filled with unfiltered water, sealed with conical caps, and secured with electrical tape to prevent leakage and evaporation.

As pesticides and pesticide degradation products and pharmaceutical compound samples were being collected, they were filtered through a glass-fiber filter into 1-L baked amber bottles. 
Each groundwater sample to be analyzed for major and minor ions, trace elements, alkalinity, and total dissolved solids analyses required filling one $250-\mathrm{mL}$ polyethylene bottle with filtered groundwater (Wilde and others, 2004). Each sample was filtered through a Whatman capsule filter. Each 250-mL filtered sample was then preserved with $7.5 \mathrm{~N}$ nitric acid. Mercury samples were collected by filtering groundwater into 250-mL glass bottles and preserving with $6 \mathrm{~N}$ hydrochloric acid. Arsenic and iron speciation samples were filtered into $250-\mathrm{mL}$ polyethylene bottles that were covered with tape to prevent light exposure and preserved with $6 \mathrm{~N}$ hydrochloric acid. Each nutrient sample was filtered into a $125-\mathrm{mL}$ brown polyethylene bottle. Samples to be analyzed for radium isotopes and gross alpha and gross beta radioactivity were filtered into 1 -L polyethylene bottles and acidified with nitric acid. Carbon isotope samples were filtered and bottom-filled into two 500-mL glass bottles that were first overfilled with three bottle volumes of groundwater. These samples had no headspace and were sealed with septum caps to avoid atmospheric contamination. Samples to be analyzed for field alkalinity titrations were collected by filtering groundwater into a 500-mL polyethylene bottle.

Samples to be analyzed for chromium, radon-222, and noble gases were collected from the hose bib at the well head. Chromium speciation samples were collected using a $10-\mathrm{mL}$ syringe with an attached $0.45-\mu \mathrm{m}$ disk filter. After the syringe was thoroughly rinsed and filled with groundwater, $4 \mathrm{~mL}$ was forced through the disk filter; the next $2 \mathrm{~mL}$ of groundwater was slowly filtered into a small centrifuge vial and analyzed for total chromium. Hexavalent chromium, Cr (VI), was then collected by attaching a small cation-exchange column to the syringe filter, and after conditioning the column with $2 \mathrm{~mL}$ of sample water, $2 \mathrm{~mL}$ were collected in a second centrifuge vial. Vials for both constituents were preserved with $7.5 \mathrm{~N}$ nitric acid (Ball and McClesky, 2003a,b).

To collect radon-222, a stainless-steel and Teflon valve assembly was attached to the sampling port at the well head (Wilde and others, 2004). The valve was partially closed to create back pressure, and a $10-\mathrm{mL}$ sample was collected through a Teflon septum on the valve assembly using a glass syringe affixed with a stainless-steel needle. Each sample was then injected into a $25-\mathrm{mL}$ vial partially filled with scintillation mixture (mineral oil) and shaken. Each vial was then placed in a cardboard tube in order to shield it from light during shipping.
Noble gases were collected in 3/8-in copper tubes using reinforced nylon tubing connected to the hose bib at the wellhead. Groundwater was flushed through the tubing to dislodge bubbles before flow was restricted with the back pressure valve. Clamps on both sides of the copper tube were tightened, trapping a sample of groundwater to be analyzed for noble gases (Weiss, 1968).

Field alkalinity was measured in the mobile laboratory at the well site. Alkalinity was measured on filtered samples using Gran's titration method (Gran, 1952). Titration data were entered directly into PCFF-GAMA and the concentrations of bicarbonate $\left(\mathrm{HCO}_{3}{ }^{-}\right)$and carbonate $\left(\mathrm{CO}_{3}{ }^{2-}\right)$ were automatically calculated from the titration data using the advanced speciation method (Stumm and Morgan, 1996; Rounds, 2006). Concentrations of $\mathrm{HCO}_{3}{ }^{-}$and $\mathrm{CO}_{3}{ }^{2-}$ were also calculated from the laboratory alkalinity and $\mathrm{pH}$ measurements. Calculations were made in a spreadsheet using the advanced speciation method (http://or.water.usgs.gov/alk/ methods.html) with $\mathrm{pK}_{1}=6.35, \mathrm{pK}_{2}=10.33$, and $\mathrm{pK}_{\mathrm{W}}=14$.

Ten laboratories did chemical analyses for this study (table A1), although most of the analyses were done at the NWQL or by laboratories contracted by the NWQL. The NWQL maintains a rigorous quality-assurance program (all concentrations were below health-based thresholds (table 5). Pirkey and Glodt, 1998; Maloney, 2005). Laboratory qualitycontrol samples, including method blanks, continuing calibration verification standards, standard reference samples, reagent spikes, external certified reference materials, and external blind proficiency samples, are analyzed regularly. Method detection limits are continuously tested and laboratory reporting levels updated accordingly. NWQL maintains the National Environmental Laboratory Accreditation Program (NELAP) and other certifications (http://nwql.usgs.gov/Public/ lab_cert.shtml). The Branch of Quality Systems within the USGS Office of Water Quality independently oversees quality assurance at the NWQL and the laboratories contracted by the NWQL. In addition, the Branch of Quality Systems runs the National Field Quality Assurance program that includes annual testing of all USGS field personnel for proficiency in making field water-quality measurements (http://qadata. cr.usgs.gov/nfqa). Results of analyses made at the NWQL or the laboratories contracted by the NWQL are uploaded directly into NWIS by the NWQL. Results of analyses made at other laboratories are compiled in a project Access (Microsoft, Redmond, WA) database and uploaded from there into NWIS. 


\section{Data Reporting}

The following section details the laboratory reporting conventions and the constituents that are determined by multiple methods of by multiple laboratories.

\section{Reporting Limits}

The USGS NWQL uses the laboratory reporting level (LRL) as a threshold for reporting analytical results. The LRL is set to minimize the reporting of false negatives (not detecting a constituent when it is actually present in a sample) to less than 1 percent (Childress and others, 1999). The LRL usually is set at two times the long-term method detection level (LT-MDL). The LT-MDL is derived from the standard deviation of at least 24 MDL determinations made over an extended period of time. LT-MDLs are continually monitored and updated. The method detection limit (MDL) is the minimum concentration of a substance that can be measured and reported with 99-percent confidence that the concentration is greater than zero (at the MDL there is less than 1 percent chance of a false positive) (Childress and others, 1999; U.S. Environmental Protection Agency, 2002). The USGS NWQL updates LRL values regularly, and the values listed in this report were in effect during the period analyses were made for groundwater samples from the COLOR area (October to December, 2007).

Concentrations between the LRL and the LT-MDL are reported as estimated concentrations (designated with an "E" before the values in the tables and text). For informationrich methods, concentrations below the LT-MDL have high certainty of being detected but the precise concentration is uncertain. Information-rich methods are those that utilize gas chromatography or high-performance liquid chromatography (HPLC) with mass spectrometry detection (VOCs and pesticides). Analytes are identified by characteristic fragmentation patterns in their mass spectra and are quantified by measurement of peak areas at their associated chromatographic retention times. E-coded values may also result from detections of concentrations outside the range of calibration standards, for detections that did not meet all laboratory quality-control criteria, and for samples that were diluted before analysis (Childress and others, 1999).

Some constituents in this study are reported using minimum reporting levels (MRLs) or method uncertainties. The MRL is the smallest measurable concentration of a constituent that may be reliably reported using a given analytical method (Timme, 1995). The method uncertainty generally indicates the precision of a particular analytical measurement; it gives a range of values wherein the true value will be found.

Results for most constituents are presented using the LRL or MRL values provided by the analyzing laboratories. Results for trace elements are presented using raised study reporting level (SRL) values derived from assessing data derived from quality-control samples associated with groundwater samples collected as part of the GAMA Priority Basin Project. The SRLs were determined by statistically assessing the analyses of the field blanks collected during the first 20 GAMA study units (May 2004 through January 2008) (Olsen and others, पिए०). The statistical analysis used order statistical and binomial probabilities to construct an upper confidence limit for the amount of contamination potentially in field blanks and, by inference, groundwater samples (Hahn and Meeker, 1991). Olsen and others (प०००) determined SRLs for trace elements that represent a confidence limit of 90 percent for the $90^{\text {th }}$ percentile of concentrations from the set of 86 field blanks used for the assessment. There is at least 90 percent confidence that no more than 10 percent of the groundwater samples would have contamination at concentrations greater than these SRLs as a result of field or laboratory processes. For constituents with SRLs greater than the respective LT-MDLs, concentrations at or below the SRL concentrations were reported as " $\leq$ " (less than or equal to) the reported concentration. Concentrations reported with the " $\leq$ " symbol are considered to be nondetections in this report.

The methods used to analyze radiochemical constituents (gross-alpha radioactivity, gross-beta radioactivity, and radium isotopes) measure activities by counting techniques (table A1). The reporting limits for radiochemical constituents are based on sample-specific critical levels $\left(\mathrm{ssL}_{\mathrm{C}}\right)$ (McCurdy and others, 2008). The critical level is analogous to the LT-MDL used for reporting analytical results for organic and non-radioactive inorganic constituents. In this report, the critical level is defined as the minimum measured activity that indicates a positive detection of the radionuclide in the sample with less than a 5 percent probability of a false positive detection. Sample-specific critical levels are used for radiochemical measurements because the critical level is sensitive to sample size and sample yield during analytical processing and depends on instrument background, counting times for the sample and background, and the characteristics of the instrument being used and the nuclide being measured. An $\mathrm{ssL}_{\mathrm{C}}$ is calculated for each sample, and the measured activity in the sample is compared with the $\mathrm{ssL}_{\mathrm{C}}$ associated with that sample. Measured activities less than the $\mathrm{ssL}_{\mathrm{C}}$ are reported as nondetections.

The analytical uncertainties associated with measuring activities are also sensitive to parameters associated with the instrumentation and sample collection. The latter include sample-specific parameters such as ample size, sample yield during analytical processing, and time elapsed between sample collection and steps in the analytical procedure. Therefore, measured activities are reported with sample-specific combined standard uncertainties (CSU). The CSU is reported at the 68 percent confidence level (1-sigma), except for radon-222, which is reported using the $2 \mathrm{CSU}$ at the 95 -percent confidence level (2-sigma). 


\section{Notation}

Stable isotopic compositions of oxygen, hydrogen, and carbon are reported as relative isotope ratios in units of per mil using the standard delta notation (Coplen and others, 2002):

$$
\delta^{i} E=\left[\frac{R_{\text {sample }}}{R_{\text {reference }}}-1\right] \cdot 1,000 \text { per mil }
$$

where

$i \quad$ is the atomic mass of the heavier isotope of

$E \quad$ is the element ( $\mathrm{O}$ for oxygen, $\mathrm{C}$ for carbon, or $\mathrm{H}$ for hydrogen);

$R_{\text {sample }}$ is the ratio of the abundance of the heavier isotope of the element $\left({ }^{18} \mathrm{O},{ }^{13} \mathrm{C}\right.$, or $\left.{ }^{2} \mathrm{H}\right)$ to the lighter isotope of the element, $\left({ }^{16} \mathrm{O},{ }^{12} \mathrm{C}\right.$, or $\left.{ }^{1} \mathrm{H}\right)$ in the sample; and, $R_{\text {reference }}$ is the ratio of the abundance of the heavier isotope of the element to the lighter isotope of the element in the reference material.

The reference material for oxygen and hydrogen is Vienna Standard Mean Ocean Water (VSMOW), which is assigned $\delta^{18} \mathrm{O}$ and $\delta^{2} \mathrm{H}$ values of 0 per mil (note than $\delta^{2} \mathrm{H}$ is sometimes referred to as $\delta \mathrm{D}$ because the common name of the heavier isotope of hydrogen, hydrogen-2, is deuterium). The reference material for carbon is Vienna Peedee Belemnite (VPDB), which is assigned a $\delta^{13} \mathrm{C}$ value of 0 per mil. Positive values indicate enrichment of the heavier isotope and negative values indicate depletion of the heavier isotope, compared with the ratios observed in the standard reference material.

\section{Constituents on Multiple Analytical Schedules}

Fourteen constituents targeted in this study were measured by more than one analytical schedule or more than one laboratory (table A2). The preferred methods for these constituents were selected on the basis of the procedure recommended by the NWQL (http://wwwnwql.cr.usgs.gov/ dyn.shtml?Preferred method selection_procedure). Methods with full approval are preferred over those with provisional approval, and approved methods are favored over research methods. The method that is more accurate and precise and has lower LRLs for the overlapping constituents is generally preferred. However, the method having higher LRLs may be selected as the preferred method to provide consistency with historical data analyzed by the same method.

For arsenic, chromium, and iron concentrations, the approved method, Schedule 1948, used by the NWQL is preferred over the research methods used by the USGS Trace Metal Laboratory. The concentrations measured by the Trace Metal Laboratory are used only to calculate ratios of redox species for each element: $\frac{\mathrm{As}(\mathrm{V})}{\mathrm{As}(\mathrm{III})}$ for arsenic, for
$\frac{\mathrm{Cr}(\mathrm{VI})}{\mathrm{Cr}(\mathrm{III})}$ chromium, and $\frac{\mathrm{Fe}(\mathrm{III})}{\mathrm{Fe}(\mathrm{II})}$ for iron. For example,

$$
\frac{\mathrm{Fe}(\mathrm{III})}{\mathrm{Fe}(\mathrm{II})}=\frac{\mathrm{Fe}(\mathrm{T})-\mathrm{Fe}(\mathrm{II})}{\mathrm{Fe}(\mathrm{II})}
$$

where

$\mathrm{Fe}(\mathrm{T})$ is the total iron concentration (measured),

$\mathrm{Fe}$ (II) is the concentration of ferrous iron (measured), and $\mathrm{Fe}(\mathrm{III})$ is the concentration of ferric iron (calculated).

\section{Quality Assurance}

The purpose of quality assurance is to identify which data best represent environmental conditions and which may have been affected by contamination or bias during sample collection, processing, storage, transportation, and (or) laboratory analysis. Four types of quality-control (QC) tests were used in this study: blank samples were collected to assess contamination, replicate samples were collected to assess reproducibility, matrix spike tests were done to assess accuracy of laboratory analytical methods, and surrogate compounds were added to samples analyzed for organic constituents to assess bias of laboratory analytical methods. The evaluation of the QC data presented in this report was based on results for QC samples collected for the COLOR and on results for QC samples collected for the 20 GAMA study units May 2004 through January 2008.

The quality-assurance methods used for this study followed the protocols used by the USGS NAWQA program (Koterba and others, 1995) and described in the USGS National Field Manual (U.S. Geological Survey, variously dated). The quality-assurance plan followed by the NWQL, the primary laboratory used to analyze samples for this study, is described by Maloney (2005) and Pirkey and Glodt (1998).

\section{Blanks}

The primary purposes of collecting blanks are to evaluate the magnitude of potential contamination of samples with analytes of interest while samples were collected handled, or analyzed, and to identify and mitigate sources of contamination. 


\section{Collection and Analysis of Blanks}

Two types of blanks were collected: source-solution and field blanks. Source-solution blanks were collected to assess potential contamination of samples during transport and analysis, and potential contamination of the certified blank water obtained from the USGS NWQL. Field blanks were collected to assess potential contamination of samples during collection, processing, transport, and analysis. Blanks were collected using blank water certified by the NWQL to contain less than the LRL or MRL of the analytes investigated in the study. Nitrogen-purged, organic-free blank water was used for field blanks of organic constituents, and inorganic-free blank water was used for field blanks of other constituents. For COLOR, blanks were collected at three sites, which is approximately 11 percent of the sites sampled. The organic constituents analyzed for in field blanks were VOCs, pesticides and pesticide degradates, pharmaceuticals, Perchlorate, 1,4-dioxane, and 1,2,3-TCP. The inorganic constituents analyzed for in field blanks were nutrients; major and minor ions; trace elements; iron, arsenic, and chromium speciation; and radium. Field-blank detections are shown on table A3. Field blanks were not collected for tritium or noble gases because they are in the atmosphere and dissolve into any solution used in collecting a blank. An indirect indicator of the quality of environmental data is tritium, whose activities are expected to be less than $3 \mathrm{pCi} / \mathrm{L}$ in water recharged before the 1950s. The presence of tritium activities below the MRL of $1 \mathrm{pCi} / \mathrm{L}$ in several samples implies that the sampling methods did not bias the results for tritium. Stable-isotope ratios of oxygen, hydrogen, carbon, nitrogen, boron, chloride, bromide, uranium, and strontium are an intrinsic property of any of these elements; therefore, the concept of a blank does not apply to these ratios.

To collect filed blanks, blank water was either pumped or poured through the sampling equipment (fittings and tubing) used to collect groundwater, then processed and transported using the same protocols used for the groundwater samples. Approximately 12 liters of blank water were pumped or poured through the sampling equipment before each field blank was collected.

\section{Analysis of Blanks}

Contamination in blanks may originate from several different types of sources that require different strategies to assess potential contamination of groundwater samples. Three primary types of contamination are assessed in the event of a field-blank or unusual groundwater detection: (1) contamination from a known source, (2) carry-over contamination from the previously collected samples, and (3) systematic and random contamination from field and laboratory equipment and processes. The third type of contamination (systematic and random) is being addressed using a larger set of field-blank results from multiple studies in addition to the results from field blanks collected at COLOR. The development of this approach and its methods are described by Olsen and Fram (2010).

Inorganic constituents are naturally present in groundwater, and the concerns about inorganic constituents generally are related to concentration rather than detection (presence or absence). In contrast, concerns about organic constituents are usually related to both detection and concentration. For inorganic constituents, a " $<$ " (less than) symbol was assigned to low-concentration detections of constituents that may have been affected by contamination. The $\leq$ symbol means that the concentration of the constituent in the groundwater sample is less than or equal to the measured concentration (including the possibility that it may be less than the LT-MDL and therefore a nondetection). For trace elements, the concentration threshold for applying the $<$ symbol was each constituent's SRL (Olsen and Fram, 2010). Concentrations below their respective SRLs were reported with $\leq$ symbol to the left of their reported concentrations.

\section{Replicates}

Sequential replicate samples were collected to assess the precision of the water-quality data. Estimates of data precision are needed to assess whether differences between concentrations in samples are due to differences in groundwater quality or to variability that may result from collecting, processing, and analyzing the samples. Relative standard deviation (RSD) of the measured values was used in determining the variability between replicate pairs for each constituent (table A4). The RSD is defined as 100 times the standard deviation divided by the mean concentration for each replicate pair of samples, expressed as a percentage. If one value for a sample pair was reported as a nondetection and the other value was reported as an estimate below the LRL or MRL (that is, an E-coded value), the RSD was set to zero because the values are analytically identical. If one value in a sample pair was reported as a nondetection and the other value was greater than the LRL or MRL, the nondetection value was set equal to a quarter of the LRL and the RSD was calculated (Hamlin and others, 2002). Values of RSD less than 20 percent are considered acceptable in this study. An RSD value equaling 20 percent corresponds to a relative percent difference (RPD) value of 29 percent. High RSD values for a constituent may indicate analytical uncertainty at low concentrations, particularly for concentrations within an order of magnitude of the LT-MDL or the MDL. Sequential replicate samples were collected at 7 percent of the wells sampled. 


\section{Matrix Spikes}

Adding a known concentration of a constituent ('spike') to a replicate environmental sample enables the analyzing laboratory to determine the effect of the matrix, in this case groundwater, on the analytical technique used to measure the constituent. The known constituent added in matrix spikes are the same as those being analyzed in the method. This enables matrix interferences to be analyzed on a constituent by constituent basis. Matrix spikes were added at the laboratory doing the analysis. A low matrix-spike recovery may indicate that the constituent was not be detected in some samples if it was present at very low concentrations. Low and high matrix-spike recoveries may be a potential concern if the concentration of a constituent in a groundwater sample is close to the MCL: a low recovery could falsely result in a measured concentration below the $\mathrm{MCL}$, whereas a high recovery could falsely result in a measured concentration above the MCL. For COLOR, matrix-spike samples were collected at approximately 11 percent of the wells sampled.

Acceptable ranges for matrix-spike recoveries are based on the acceptable ranges established for laboratory "set" spike recoveries. Laboratory-set spikes are aliquots of laboratory blank water to which the same spike solution used for the matrix spikes has been added. One set spike is analyzed with each set of samples. Acceptable ranges for set spike recoveries are 70 to 130 percent for VOCs (Connor and others, 1998; Rose and Sandstrom, 2003), 60 to 120 percent for pesticides and pesticide degradates (Sandstrom and others, 2001), and 60 to 130 percent for Schedule 9003 (Kolpin and others, 2002). On the basis of these ranges, 70 to 130 percent was defined as the acceptable range for matrix-spike recoveries for organic constituents in this study.

Matrix spike recovery tests were done for VOCs, pesticides, pharmaceuticals (not reported in this document), 1,4-dioxane, and 1,2,3-TCP because the analytical methods for these constituents are chromatographic methods that may be susceptible to matrix interferences (tables A5A-C).

\section{Surrogates}

Surrogate compounds are added to environmental samples in the laboratory before analysis in order to evaluate the recovery of similar constituents. Surrogate compounds were added to all groundwater and quality-control samples that were analyzed for VOCs, pesticides, and pharmaceuticals (pharmaceutical data will be presented in a subsequent report). Most of the surrogate compounds are deuterated analogs of compounds being analyzed. For example, the surrogate toluene- $d 8$ used for the VOC analytical method has the same chemical structure as toluene, except that the eight hydrogen-1 atoms on the molecule have been replaced by deuterium (hydrogen-2). Toluene- $d 8$ and toluene behave very similarly in the analytical procedure, but the small mass difference between the two results in slightly different chromatographic retention times; thus, using a toluene- $d 8$ surrogate does not interfere with analyzing toluene (Grob, 1995). Only 0.015 percent of hydrogen atoms are deuterium (Firestone and others, 1996). Thus, deuterated compounds like toluene- $d 8$ do not exist naturally and are not found in environmental samples. Surrogates are used to identify general problems that may arise during sample analysis that could affect the analysis results for all compounds in that sample. Potential problems include matrix interferences (such as high levels of dissolved organic carbon) that produce a positive bias, or incomplete laboratory recovery (possibly as a result of improper maintenance and calibration of analytical equipment) that produces a negative bias. A 70 to 130 percent recovery of surrogates is generally considered acceptable; values outside this range indicate possible problems with processing and analyzing samples (Connor and others, 1998; Sandstrom and others, 2001).

\section{Quality-Control Results}

\section{Detections of Constituents in Field and Source-Solution Blanks}

Field blanks were collected at 3 of the 28 sites, equaling approximately 10 percent of the sites sampled in COLOR. Table A3 gives a summary of detections of constituents in field blanks. No organic constituents were detected in field blanks. The inorganic constituents boron and silica were detected in the field blanks. These constituents were known to be present in the inorganic blank water obtained from the NWQL. No groundwater samples had boron and silica concentrations less than their concentrations detected in the respective blank samples. Zinc was detected in one blank sample at a concentration of $1.7 \mu \mathrm{g} / \mathrm{L}$ which is less than the SRL of 4.8 $\mu \mathrm{g} / \mathrm{L}$. Groundwater samples containing zinc concentrations less than the SRL were therefore coded with the " $\leq$ " symbol (tables 10, A3). Radium-226 was detected in one blank sample at a concentration of $0.02 \mathrm{pCi} / . \mathrm{L}$ No environmental samples had activities equal to or less than this activity measured in the blank. Radium-228 was not detected in blank samples.

No constituents in the following analyte groups were detected in the field blanks: VOCs; pesticide and pesticide degradates; perchlorate; 1,4-dioxane; 1,2,3-TCP; major and minor ions; arsenic, chromium, and iron species; and nutrients. 


\section{Variability in Replicate Samples}

Table A4 summarizes the results of replicate analyses of constituents detected in groundwater samples collected in for the COLOR. Most replicate analyses yielded RSD values less than 5 percent and only 12 replicate analyses yielded RSD values greater than the acceptable limit of 20 percent. However, the concentrations of constituents in all the replicate sample pairs, except the two mercury pairs, with RSD values greater than 20 percent were within a factor of five of the LT-MDLs for the respective analytes. At these low concentrations, small deviations in measured values result in large RSDs.

\section{Matrix-Spike Recoveries}

Tables A5A-C summarize matrix-spike recoveries for the COLOR. Three environmental samples were spiked with VOCs so that matrix-spike recoveries could be calculated (table A5A). Two of the 85 VOC spike compounds had median recoveries outside of the acceptable range of 70 to 130 percent. These two constituents were not detected in environmental samples. Low recoveries may indicate that these compounds might not have been detected in some samples if their concentrations were very low.

Thirteen of the 62 pesticide and pesticide degradate spike constituents had at least one median recovery below 70 percent, and one spike constituent had at least one recovery above 130 percent (table A5B). One of the constituents that had a low spike recovery, deethylatrazine, was detected in environmental samples. Two groundwater samples were spiked with 1,4-dioxane and 1,2,3-Trichlorporpane (1,2,3TCP). The spike recoveries were within the acceptable range of 70 to 130 percent for 1,4-dioxane, but 1,2,3-TCP recoveries were below 70 percent (table A5C). 1,2,3-TCP was detected in one environmental sample. Low recoveries may indicate that these compounds might not have been detected in some samples if they were present at very low concentrations.

\section{Surrogate Compound Recoveries}

Surrogate compounds were added to environmental samples in the laboratory to help determine the precision and accuracy of analytical methods and equipment used to analyze the samples. Table A6 lists the surrogate, the analytical schedule on which it was applied, the number of analyses for blank and non-blank samples, the number of surrogate recoveries below 70 percent, and the number of surrogate recoveries above 130 percent for the blanks and groundwater samples. Blanks and groundwater samples were considered separately to assess whether the matrices present in the groundwater samples affect surrogate recoveries. No systematic differences between surrogate recoveries in the blanks and the groundwater samples were observed. 
Table A1. Analytical methods used to measure organic and inorganic constituents by the U.S. Geological Survey (USGS) National Water Quality Laboratory (NWOL) and other laboratories.

[Laboratory entity codes in the USGS National Water Information System (NWIS) for laboratories other than the USGS National Water Quality Laboratory (NWQL) are given in parentheses after the laboratory names. VOC, volatile organic compound; HPLC, high-performance liquid chromatography; UV, ultraviolet]

\begin{tabular}{|c|c|c|c|}
\hline Analyte & Analytical method & Laboratory and analytical schedule & Citation(s) \\
\hline $\begin{array}{l}\text { Field parameters ( } \mathrm{pH} \text {, specific } \\
\text { conductance, temperature) }\end{array}$ & $\begin{array}{l}\text { Calibrated field meters and test } \\
\text { kits }\end{array}$ & USGS field measurement & $\begin{array}{l}\text { U.S. Geological Survey, } \\
\text { variously dated }\end{array}$ \\
\hline \multicolumn{4}{|c|}{ Organic constituents } \\
\hline VOCs & $\begin{array}{l}\text { Purge and trap capillary gas } \\
\text { chromatography/mass } \\
\text { spectrometry }\end{array}$ & NWQL, Schedule 2020 & Connor and others, 1998 \\
\hline Pesticides and degradates & $\begin{array}{l}\text { Solid-phase extraction and } \\
\text { gas chromatography/mass } \\
\text { spectrometry }\end{array}$ & NWQL, Schedule 2003 & $\begin{array}{l}\text { Zaugg and others, 1995; Lindley } \\
\text { and others, 1996; Madsen and } \\
\text { others, 2003; Sandstrom and } \\
\text { others, } 2001\end{array}$ \\
\hline Pharmaceuticals & $\begin{array}{l}\text { Solid-phase extraction and } \\
\text { HPLC/mass spectrometry }\end{array}$ & NWQL, Schedule 9003 & $\begin{array}{l}\text { Kolpin and others, 2002; Furlong } \\
\text { and others, } 2008\end{array}$ \\
\hline 1,2,3-Trichloropropane & $\begin{array}{l}\text { Isotopic dilution purge and trap/ } \\
\text { gas chromatography/mass } \\
\text { spectrometry }\end{array}$ & $\begin{array}{l}\text { Weck Laboratories, Inc., standard } \\
\text { operating procedure ORG083 }\end{array}$ & Okamoto and others, 2002 \\
\hline 1,4-Dioxane & $\begin{array}{l}\text { Isotopic dilution gas } \\
\text { chromatography/mass } \\
\text { spectrometry (USEPA Method } \\
\text { 8270C modified) }\end{array}$ & $\begin{array}{l}\text { Weck Laboratories, Inc., standard } \\
\text { operating procedure ORG043.R3 }\end{array}$ & $\begin{array}{l}\text { U.S. Environmental Protection } \\
\text { Agency, 1996; Draper and } \\
\text { others, } 2000\end{array}$ \\
\hline \multicolumn{4}{|c|}{ Inorganic constituents } \\
\hline Nutrients & $\begin{array}{l}\text { Alkaline persulfate digestion, } \\
\text { Kjedahl digestion }\end{array}$ & NWQL, Schedule 2755 & $\begin{array}{l}\text { Fishman, 1993; Patton and } \\
\text { Kryskalla, } 2003\end{array}$ \\
\hline $\begin{array}{l}\text { Chromium, arsenic and iron } \\
\text { speciation }\end{array}$ & $\begin{array}{l}\text { Various techniques of } \\
\text { ultraviolet visible (UV-VIS) } \\
\text { spectrophotometry and atomic } \\
\text { absorbance spectroscopy }\end{array}$ & $\begin{array}{l}\text { USGS Trace Metal Laboratory, } \\
\text { Boulder, Colorado } \\
\text { (USGSTMCO) }\end{array}$ & $\begin{array}{l}\text { Stookey, 1970; To and others, } \\
\text { 1998; Ball and McCleskey, } \\
\text { 2003a,b; McCleskey and } \\
\text { others, } 2003\end{array}$ \\
\hline \multicolumn{4}{|c|}{ Stable isotopes } \\
\hline $\begin{array}{l}\text { Stable isotopes of hydrogen } \\
\text { and oxygen in water }\end{array}$ & $\begin{array}{l}\text { Gaseous hydrogen and carbon } \\
\text { dioxide-water equilibration } \\
\text { and stable-isotope mass } \\
\text { spectrometry }\end{array}$ & $\begin{array}{l}\text { USGS Stable Isotope Laboratory, } \\
\text { Reston, Virginia (USGSSIVA), } \\
\text { NWQL Schedule } 1142\end{array}$ & $\begin{array}{l}\text { Epstein and Mayeda, 1953; } \\
\text { Coplen and others, 1991; } \\
\text { Coplen, } 1994\end{array}$ \\
\hline Carbon isotopes & Accelerator mass spectrometry & $\begin{array}{l}\text { University of Waterloo, } \\
\text { Environmental Isotope Laboratory } \\
\text { (CAN-UWIL); University of } \\
\text { Arizona Accelerator Mass } \\
\text { Spectrometry Laboratory (AZ- } \\
\text { UAMSL), NWQL Schedule } 2015\end{array}$ & $\begin{array}{l}\text { Donahue and others, 1990; Jull } \\
\text { and others, } 2004\end{array}$ \\
\hline
\end{tabular}


Table A1. Analytical methods used to measure organic and inorganic constituents by the U.S. Geological Survey (USGS) National Water Quality Laboratory (NWOL) and other laboratories.-Continued

[Laboratory entity codes in the USGS National Water Information System (NWIS) for laboratories other than the USGS National Water Quality Laboratory (NWQL) are given in parentheses after the laboratory names. VOC, volatile organic compound; HPLC, high-performance liquid chromatography; UV, ultraviolet]

\begin{tabular}{|c|c|c|c|}
\hline Analyte & Analytical method & Laboratory and analytical schedule & Citation(s) \\
\hline \multicolumn{4}{|c|}{ Radioactivity and gases } \\
\hline Tritium & $\begin{array}{l}\text { Electrolytic enrichment-liquid } \\
\text { scintillation }\end{array}$ & $\begin{array}{l}\text { USGS Stable Isotope and Tritium } \\
\text { Laboratory, Menlo Park, } \\
\text { California (USGSH3CA) }\end{array}$ & Thatcher and others, 1977 \\
\hline Tritium and noble gases & $\begin{array}{l}\text { Helium-3 in-growth and mass } \\
\text { spectrometry }\end{array}$ & $\begin{array}{l}\text { Lawrence Livermore National } \\
\text { Laboratory (CA-LLNL) }\end{array}$ & $\begin{array}{l}\text { Moran and others, 2002; Eaton } \\
\text { and others, } 2004\end{array}$ \\
\hline Radium isotopes & Alpha activity counting & $\begin{array}{l}\text { Eberline Analytical Services (CA- } \\
\text { EBERL), NWQL Schedule } 1262\end{array}$ & $\begin{array}{l}\text { Kreiger and Whittaker, } 1980 \\
\text { (USEPA methods } 903 \text { and } \\
\text { 904) }\end{array}$ \\
\hline $\begin{array}{l}\text { Gross alpha and beta } \\
\text { radioactivity }\end{array}$ & Alpha and beta activity counting & $\begin{array}{l}\text { Eberline Analytical Services, NWQL } \\
\text { Schedule } 1792\end{array}$ & $\begin{array}{l}\text { Kreiger and Whittaker, 1980 } \\
\text { (USEPA method 900.0) }\end{array}$ \\
\hline
\end{tabular}


Table A2. Preferred analytical schedules for constituents appearing on multiple schedules for samples collected for the Colorado River Groundwater Ambient Monitoring and Assessment (GAMA) study, California, autumn 2007.

[Of the methods used to analyze the compound in question, analytical schedules that are the most accurate and precise are preferred except when consistency with historic data analyzed using the same method is preferred. Laboratory: LLNL, Lawrence Livermore National Laboratory; MWH, Montgomery Watson Harza Laboratory; SITL, U.S. Geological Survey Stable Isotope and Tritium Laboratory; TML, U.S. Geological Survey Trace Metal Laboratory, Boulder, Colorado; WECK, Weck Laboratories, Inc. Other abbreviations: VOC, volatile organic compound; -, no preference]

\begin{tabular}{llcc}
\hline \multicolumn{1}{c}{ Constituent } & \multicolumn{1}{c}{$\begin{array}{c}\text { Primary constituent } \\
\text { classification }\end{array}$} & Analytical schedules & $\begin{array}{c}\text { Preferred analytical } \\
\text { schedule }\end{array}$ \\
\hline Acetone & \multicolumn{1}{c}{ Results from preferred method reported } & \\
tert-Amyl methyl ether (TAME) & Solvent & 2020,4024 & 2020 \\
Diisopropyl ether (DIPE) & Gasoline oxygenate & 2020,4024 & 2020 \\
Ethyl tert-butyl ether (ETBE) & Gasoline oxygenate & 2020,4024 & 2020 \\
Methyl tert-butyl ether (MTBE) & Gasoline oxygenate & 2020,4024 & 2020 \\
\hline \multicolumn{1}{c}{ Gasoline oxygenate } & 2020,4024 & 2020 \\
\hline Alkalinity & \multicolumn{1}{c}{ Results from both methods reported } & Field \\
Arsenic, total & Water-quality indicator & 1948, field & 1948 \\
Chromium, total & Trace element & 1948, TML & 1948 \\
Iron, total & Trace element & 1948, TML & 1948 \\
pH & Trace element & 1948, TML & Field \\
Specific conductance & Water-quality indicator & 1948, field & Field \\
Perchlorate & Water-quality indicator & 1948, field & WECK \\
1,2,3-Trichloropropane (1,2,3-TCP) & VOC & MWH, WECK & WECK \\
Tritium & Ssotope tracer & 2020, WECK & - \\
\hline
\end{tabular}

Table A3. Constituents detected in field blanks collected for the Colorado River Groundwater Ambient Monitoring and Assessment (GAMA) study, California, autumn 2007.

[mg/L, milligram per liter; $\mu \mathrm{g} / \mathrm{L}$, microgram per liter; $\mathrm{pCi} / \mathrm{L}$, picocurie per liter; na, not applicable; $\leq$, less than or equal to]

\begin{tabular}{lcc}
\hline Constituent & $\begin{array}{c}\text { Number of field blank } \\
\text { detections/analyses }\end{array}$ & $\begin{array}{c}\text { Concentrations detected } \\
\text { in field blanks }\end{array}$ \\
\hline None & Organic constituents & na \\
\hline & $0 / 3$ & $20.8 ; 25.2$ \\
\hline Boron $(\mu \mathrm{g} / \mathrm{L})$ & Inorganic constitutents & $0.03,0.04$ \\
Silica $(\mathrm{mg} / \mathrm{L})$ & $2 / 3$ & $\leq 1.7$ \\
\hline Zinc ${ }^{1}(\mu \mathrm{g} / \mathrm{L})$ & $2 / 3$ & 0.02 \\
\hline & $1 / 3$ & \\
\hline Radium-226 & Radioactive constituents $(\mathrm{pC} / \mathrm{L})$ & \\
\hline${ }^{1}$ Study reporting levels $($ SRL) for constituents were based on examinations of GAMA quality-control samples collected May 2004 through
\end{tabular}


Table A4. Quality-control summary of replicate analyses of constituents detected in samples collected for the Colorado River Groundwater Ambient Monitoring and Assessment (GAMA) study, California, autumn 2007.

[E, estimated value; mg/L, milligram per liter; $\mu \mathrm{g} / \mathrm{L}$, microgram per liter; $\mathrm{pCi} / \mathrm{L}$, picocurie per liter; nv, no values in category; TU, tritium unit; $<$, less than]

\begin{tabular}{|c|c|c|c|}
\hline Constituent & $\begin{array}{c}\text { Number of relative } \\
\text { standard deviations } \\
\text { greater than } 20 \text { percent/ } \\
\text { number of replicate pairs }\end{array}$ & $\begin{array}{l}\text { Maximum relative } \\
\text { standard deviation } \\
\text { (percent) }\end{array}$ & $\begin{array}{l}\text { Concentrations or activities for } \\
\text { replicates with RSD greater } \\
\text { than } 20 \text { percent (environmenta } \\
\text { sample; replicate) }\end{array}$ \\
\hline \multicolumn{4}{|c|}{ Volatile organic compounds from schedule 2020} \\
\hline 1,2,4-Trimethylbenzene $(\mu \mathrm{g} / \mathrm{L})$ & $1 / 2$ & 53 & $(0.09 ;<0.04)$ \\
\hline \multicolumn{4}{|c|}{ Pesticides and pesticide degradates from schedule 2003} \\
\hline \multicolumn{4}{|c|}{ Constituents of special interest ${ }^{1}$} \\
\hline Perchlorate $(\mu \mathrm{g} / \mathrm{L})$ & $1 / 2$ & 53 & $(2.2 ; 1.0)$ \\
\hline 1,2,3-Trichloropropane and 1,4 dioxane $(\mu \mathrm{g} / \mathrm{L})$ & $0 / 2$ & $<20$ & nv \\
\hline \multicolumn{4}{|c|}{ Major ions, minor ions, trace elements, and nutrients } \\
\hline \multicolumn{4}{|c|}{ Isotopes, radioactivity, and noble gases } \\
\hline Radium-226 2 (pCi/L) & $1 / 2$ & 55 & $(0.024 ; 0.055)$ \\
\hline Radium-228 ${ }^{2}$ (pCi/L) & $0 / 2$ & $<20$ & nv \\
\hline Gross alpha radioactivity, 72-hour count ${ }^{2}$ (pCi/L) & $1 / 2$ & 35 & $(57 ; 34)$ \\
\hline Gross alpha radioactivity, 30-day count ${ }^{2}(\mathrm{pCi} / \mathrm{L})$ & $2 / 2$ & 141 & $(0 ; 3.8)(52.2 ; 26.2)$ \\
\hline Gross beta radioactivity, 72-hour count ${ }^{2}$ (pCi/L) & $2 / 2$ & 34 & $(6.4 ; 3.9)(7.5 ; 4.9)$ \\
\hline Gross beta radioactivity, 30 -day count ${ }^{2}(\mathrm{pCi} / \mathrm{L})$ & $1 / 2$ & 29 & $(12.8 ; 19.3)$ \\
\hline Stable isotopes & $0 / 2$ & $<20$ & $\mathrm{nv}$ \\
\hline
\end{tabular}

${ }^{1}$ Analysed at Weck Laboratories, Inc., City of Industry, California.

${ }^{2}$ Analysed at the Eberline Analytical Services laboratory, Richmond, California.

${ }^{3}$ Analysed at the U.S. Geological Survey Stable Isotope and Tritium Laboratory, Menlo Park, California.

${ }^{4}$ Analysed at the Lawrence Livermore National Laboratory, Livermore, California. 
Table A5A. Quality-control summary of matrix-spike recoveries of volatile organic compounds (VOC) in samples collected for the Colorado River Groundwater Ambient Monitoring and Assessment (GAMA) study, California, autumn 2007.

[Acceptable recovery range is between 70 and 130 percent]

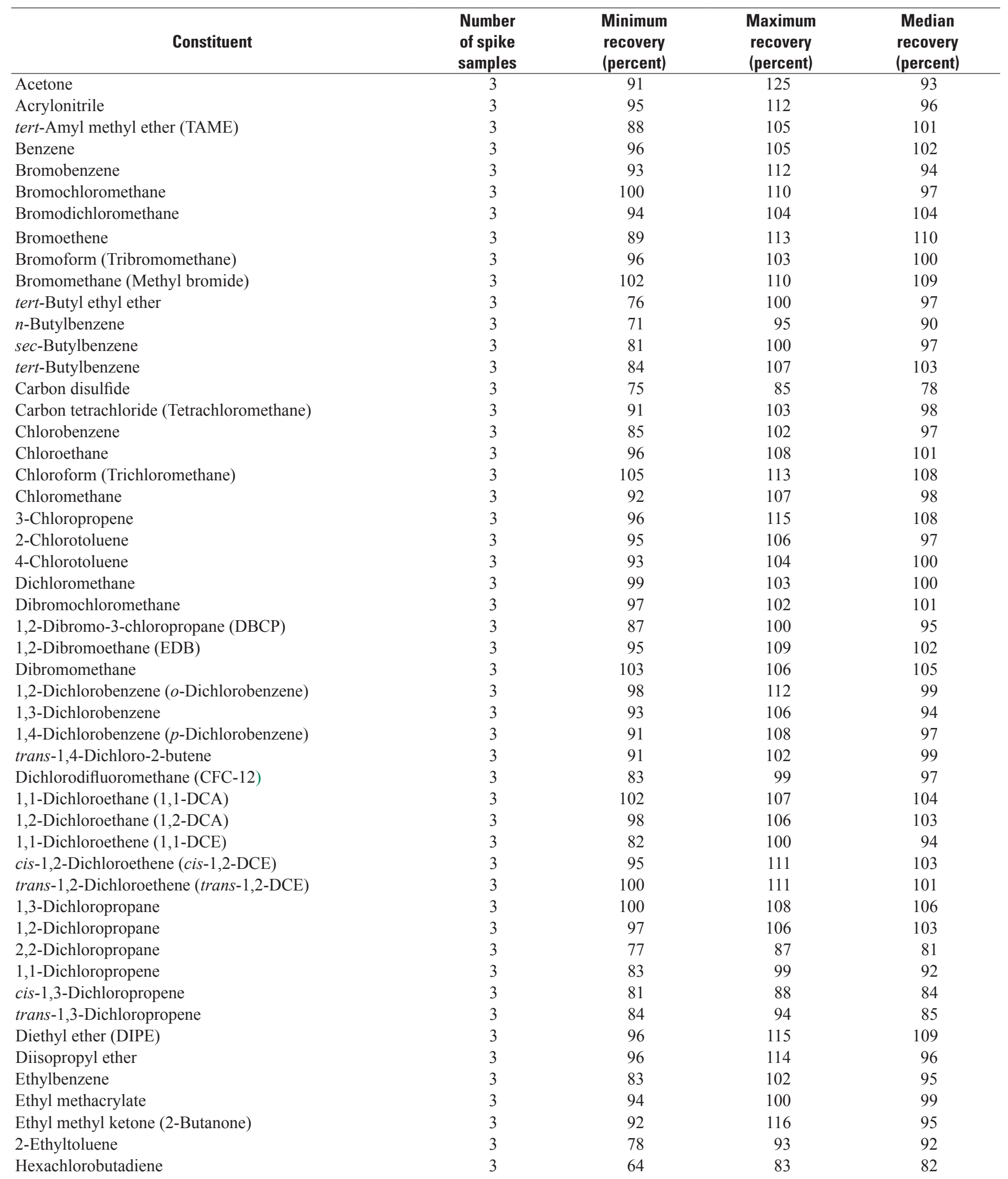


Table A5A. Quality-control summary of matrix-spike recoveries of volatile organic compounds (VOC) in samples collected for the Colorado River Groundwater Ambient Monitoring and Assessment (GAMA) study, California, autumn 2007._-Continued

[Acceptable recovery range is between 70 and 130 percent]

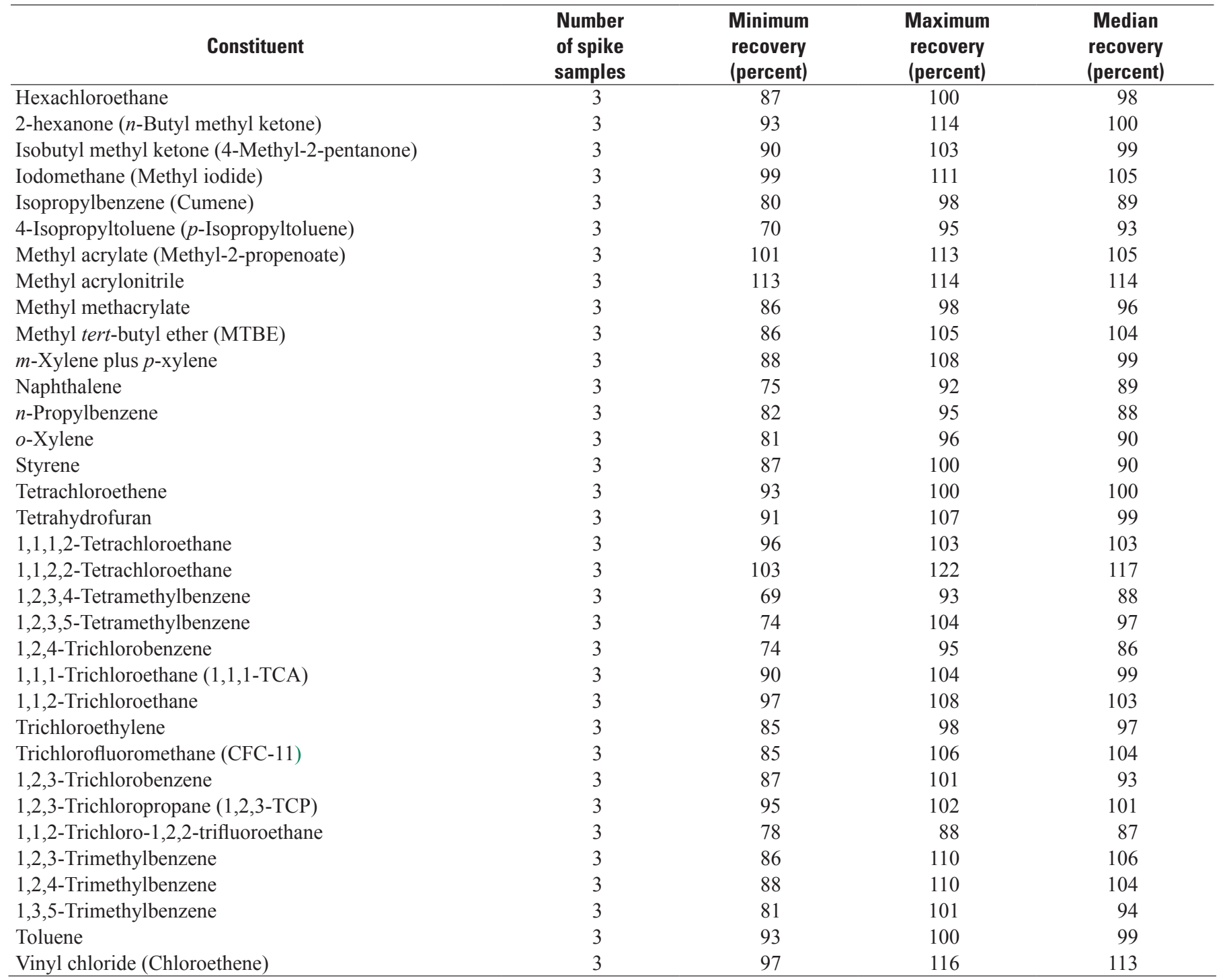


Table A5B. Quality-control summary of matrix-spike recoveries of pesticides and pesticide degradates in samples collected for the Colorado River Groundwater Ambient Monitoring and Assessment (GAMA) study, California, autumn 2007.

[Acceptable recovery range is between 70 and 130 percent]

\begin{tabular}{|c|c|c|c|c|}
\hline Constituent & $\begin{array}{c}\text { Number of } \\
\text { spike samples }\end{array}$ & $\begin{array}{l}\text { Minimum } \\
\text { recovery } \\
\text { (percent) }\end{array}$ & $\begin{array}{c}\text { Maximum } \\
\text { recovery } \\
\text { (percent) }\end{array}$ & $\begin{array}{l}\text { Median } \\
\text { recovery } \\
\text { (percent) }\end{array}$ \\
\hline Acetochlor & 3 & 111 & 114 & 113 \\
\hline Alachlor & 3 & 109 & 110 & 109 \\
\hline Atrazine & 3 & 97 & 110 & 97 \\
\hline Benfluralin & 3 & 71 & 76 & 75 \\
\hline Carbaryl & 3 & 100 & 116 & 114 \\
\hline 2-Chloro-2',6'-diethylacetanilide & 3 & 105 & 113 & 109 \\
\hline 4-Chloro-2-methylphenol & 3 & 62 & 67 & 67 \\
\hline Cypermethrin & 3 & 53 & 93 & 93 \\
\hline Dacthal (DCPA) & 3 & 103 & 112 & 104 \\
\hline $\begin{array}{l}\text { Deethylatrazine (2-Chloro-4-isopropylamino- } \\
\text { 6-amino-s-triazine; CIAT) }\end{array}$ & 3 & 47 & 55 & 53 \\
\hline Desulfinylfipronil amide & 3 & 96 & 109 & 104 \\
\hline Desulfinyl fipronil & 3 & 87 & 97 & 94 \\
\hline Diazinon & 3 & 95 & 107 & 99 \\
\hline 3,4-Dichloroaniline & 3 & 83 & 92 & 86 \\
\hline Dichlorvos & 3 & 14 & 27 & 23 \\
\hline 2-Ethyl-6-methylaniline & 3 & 88 & 99 & 95 \\
\hline Fenamiphos sulfone & 3 & 91 & 120 & 92 \\
\hline Fenamiphos sulfoxide & 3 & 13 & 59 & 39 \\
\hline Fenamiphos & 3 & 120 & 126 & 125 \\
\hline Fipronil & 3 & 102 & 121 & 114 \\
\hline Fipronil sulfide & 3 & 94 & 104 & 101 \\
\hline Fipronil sulfone & 3 & 74 & 89 & 83 \\
\hline Fonofos & 3 & 92 & 100 & 98 \\
\hline Hexazinone & 3 & 87 & 89 & 87 \\
\hline Iprodione & 3 & 43 & 60 & 59 \\
\hline Isofenphos & 3 & 116 & 131 & 124 \\
\hline Malaoxon & 3 & 76 & 99 & 82 \\
\hline Malathion & 3 & 99 & 111 & 111 \\
\hline Metalaxyl & 3 & 97 & 108 & 101 \\
\hline
\end{tabular}


Table A5B. Quality-control summary of matrix-spike recoveries of pesticides and pesticide degradates in samples collected for the Colorado River Groundwater Ambient Monitoring and Assessment (GAMA) study, California, autumn 2007.—Continued

[Acceptable recovery range is between 70 and 130 percent]

\begin{tabular}{|c|c|c|c|c|}
\hline Constituent & $\begin{array}{c}\text { Number of } \\
\text { spike samples }\end{array}$ & $\begin{array}{l}\text { Minimum } \\
\text { recovery } \\
\text { (percent) }\end{array}$ & $\begin{array}{c}\text { Maximum } \\
\text { recovery } \\
\text { (percent) }\end{array}$ & $\begin{array}{l}\text { Median } \\
\text { recovery } \\
\text { (percent) }\end{array}$ \\
\hline Methidathion & 3 & 107 & 136 & 113 \\
\hline Metolachlor & 3 & 103 & 108 & 103 \\
\hline Metribuzin & 3 & 82 & 98 & 92 \\
\hline Myclobutanil & 3 & 110 & 129 & 113 \\
\hline Paraoxon-methyl & 3 & 51 & 61 & 58 \\
\hline Parathion-methyl & 3 & 89 & 91 & 90 \\
\hline Pendimethalin & 3 & 117 & 123 & 119 \\
\hline cis-Permethrin & 3 & 74 & 103 & 81 \\
\hline Phosmet oxon & 2 & 49 & 50 & 49.5 \\
\hline Prometon & 3 & 96 & 115 & 103 \\
\hline Prometryn & 3 & 105 & 117 & 108 \\
\hline Pronamide (Propyzamide) & 3 & 92 & 110 & 108 \\
\hline Simazine & 3 & 95 & 111 & 103 \\
\hline Tebuthiuron & 3 & 90 & 148 & 102 \\
\hline Terbufos & 3 & 111 & 265 & 218 \\
\hline Terbufos oxygen oxon sulfone & 3 & 79 & 97 & 82 \\
\hline Terbuthylazine & 3 & 106 & 113 & 108 \\
\hline
\end{tabular}


Table A5C. Quality-control summary for matrix-spike recoveries of 1,4-dioxane and 1,2,3-trichloropropane (1,2,3-TCP) in groundwater samples collected for the Colorado River Groundwater Ambient Monitoring and Assessment (GAMA) study, California, autumn 2007.

[Acceptable recovery range is between 70 and 130 percent]

\begin{tabular}{|c|c|c|c|}
\hline Constituent & Number of spike samples & $\begin{array}{l}\text { Minimum } \\
\text { recovery } \\
\text { (percent) }\end{array}$ & $\begin{array}{c}\text { Maximum } \\
\text { recovery } \\
\text { (percent) }\end{array}$ \\
\hline 1,4-Dioxane & 2 & 109 & 111 \\
\hline 1,2,3-Trichloropropane ${ }^{1}$ & 2 & 67 & 69 \\
\hline
\end{tabular}

${ }^{1}$ Constituent detected in groundwater samples.

Table A6. Quality-control summary for surrogate recoveries of volatile organic compounds, pesticides and pesticide degradates, and constituents of special interest in samples collected for the Colarado River Groundwater Ambient Monitoring and Assessment (GAMA) study, California, autumn 2007.

[VOC, volatile organic compound; nv, no value]

\begin{tabular}{|c|c|c|c|c|c|c|}
\hline Surrogate & $\begin{array}{l}\text { Analytical } \\
\text { schedule }\end{array}$ & $\begin{array}{l}\text { Constituent } \\
\text { class } \\
\text { analyzed }\end{array}$ & $\begin{array}{l}\text { Number of } \\
\text { analyses }\end{array}$ & $\begin{array}{l}\text { Median } \\
\text { recovery } \\
\text { (percent) }\end{array}$ & $\begin{array}{c}\text { Number } \\
\text { of surrogate } \\
\text { recoveries } \\
\text { below } \\
70 \text { percent }\end{array}$ & $\begin{array}{c}\text { Number } \\
\text { of surrogate } \\
\text { recoveries } \\
\text { above } \\
130 \text { percent }\end{array}$ \\
\hline \multicolumn{7}{|c|}{ Blanks } \\
\hline 1-Bromo-4-fluorobenzene & 2020 & VOC & 3 & 75 & 0 & 0 \\
\hline Toluene- $d 8$ & 2020 & VOC & 3 & 93 & 0 & 0 \\
\hline Isobutyl alcohol- $d 6$ & 4024 & Gasoline oxygenate & 0 & $\mathrm{nv}$ & nv & nv \\
\hline Diazinon- $d 10$ & 2003 & Pesticide & 3 & 95 & 0 & 0 \\
\hline$\alpha-\mathrm{HCH}-d 6$ & 2003 & Pesticide & 3 & 84 & 0 & 0 \\
\hline \multicolumn{7}{|c|}{ Groundwater, replicate, and matrix-spike test samples } \\
\hline Isobutyl alcohol- $d 6$ & 4024 & Gasoline oxygenate & 2 & 89 & 0 & 0 \\
\hline Diazinon- $d 10$ & 2003 & Pesticide & 28 & 99 & 0 & 0 \\
\hline$\alpha-\mathrm{HCH}-d 6$ & 2003 & Pesticide & 28 & 83 & 0 & 0 \\
\hline
\end{tabular}


Manuscript approved for publication, September 30, 2009

Prepared by the USGS Enterprise Publishing Network

Sacramento Publishing Service Center

For more information concerning the research in this report, contact the

Director, California Water Science Center

U.S. Geological Survey

6000 J Street, Placer Hall

Sacramento, California 95819

http://ca.water.usgs.gov 
